\title{
Encarnación y muerte redentoras
}

\section{LA HUMANIZACIÓN DEL HIJO DE DiOS *}

La fe de la Iglesia — cristalizada en este artículo del Símbolo y atestiguada por sus más autorizados comentaristas - confiesa que el Hijo de Dios se encarnó y se hizo verdadero hombre por nosotros, siendo concebido por el Espíritu Santo en el seno de la Virgen María, verdadera Madre de Dios. Con ello se afirma, que el Dios eterno se reveló como Amor «alienándose» o entrando definitiva y plenamente en la historia humana, para redimirla. Y lo hizo mediante María: ¡Por medio de una mujer se humanizó el Hijo de Dios, para divinizar al hombre! Todo esto no es invención legendaria del mito ni filosófica elucubración de la razón humana, sino verdad enraizada en la revelación neotestamentaria y asequible sólo a quien cree.

* Además de los comentarios a este artículo del Símbolo (C. Blúme, o.c., 127-62; S. Bäumer, o.c., 186-89; F. Kattenbusch, o.c., II 616-25.879-87; I. Ortiz de Urbina, o. t:, 224-44; AA.VV., Il Simbolo, V-VI, Assisi ${ }^{2}$ 1955.1949; J. Ratzinger, o.c., 222-30: trad. 'españ.,; 235-44; W. Beinert, o.c., 84-95; H. Urs von Balthasar, «Ich glaube» [hrsg. W. Sandfuchs], Würzburg ${ }^{3}$ 1975, 39-49; C. Pozo, o.c.. [El Credo.], 95-104.130-33; J. Honoré-J.M. Thomas, "La foi de l'Église», 161-210; Ph. Schäfer, o.c., 45-52: trad. españ.; 63-73; AA.VV., «Se encarnó y se hizo hombre»: [Communio IV.1] Madrid 1979; R. Blázquez, Creo en Jesús de Nazaret, nacido de la 


\section{EL HECHO DE LA ENCARNACIÓN}

Además de la bibliografía citada, Cf.: M.-E. Bolsmard, Le Prologue de saint Jean (LD 11), Paris 1953, 66-79; P. HENRY, Kenose: DBS V 7-161: 16-34; R. SCHNACKENBURG, Das Johannesevangelium, I, Freiburg 1964, 241-49 (trad. españ., 282-89); "Y la Palabra se hizo carne»: Com. 4 (1979) 20-28; R.E. BRown, The Gospel acc. to St. John, I, Garden City 1966, 13-14.30-35 (trad.españ., 185-87.207-12); H. van den Bussche, Jean, Bruges 1967, 96-103; A. FEuILLE, Le Prologue du quatrième Évangile, Paris 1968, 95-118; J. GNILKA, Der Philipperbrief, Freiburg 1968, 112-24; G. RichTER, Die Fleischwerdung des Logos im Johannesevangelium: NT 13 (1971) 81-126; J. ALFARO, Cristología y antropología, Madrid 1973, 121-40; K. RAHNER, Curso fundamental sobre la fe, Barcelona 1979, 253-71.

1) Una de las verdades centrales, confesada por las primeras comunidades cristianas, fue sin duda la encarnación del Hijo de Dios, «manifestado en la carne», o «nacido del linaje de David según la carne» al ser enviado por Dios «en una carne semejante a la del pecado» y «nacido de mujer» israelita, por lo que de los israelitas «procede Cristo según la carne» 1. Esta insistencia en subrayar el envío, nacimiento y manifestación del Hijo de Dios «en la carne» no fue exclusiva de las comunidades paulinas, pues también la comunidad joannea -en polémica antidoceta- «confiesa a Jesucristo venido en

Virgen María: «El Credo de los cristianos», 45-64: 60ss), Cf. en particular: A. Michel, Incarnation: DThC VII 1445-1539; L. Cerfaux, Le Christ dans la théologie de saint Paul (LD 6), Paris ${ }^{2}$ 1954, 127-48; M. Schmaus, Teología Dogmática, III, Madrid 1959, 139-236; H. Vorgrimler, Hypostatische Union: LThK V 579-84; Inkarnation: Ib., 678s; L. Legrand, Fecondité virginale selon l'Esprit dans le NT: NRTh 84(1962) 785-805; K. Rahner, Para la teología de la Encarnación: ET IV (Madrid 1964) 139-57; Encarnación: SM II 549-67 (bibliogr.); J. Liebaert, Christologie (HDG, III.la), Freiburg 1965; A. Müller, Puesto de María y su cooperación en el acontecimiento Cristo: MS III.2, 405-521: 438-86; C. Pozo, María en la obra de la salvación, Madrid 1974, 207-33.250-313; M. M. González Gil, Cristo, el misterio de Dios, I, Madrid 1976, 173-301; F. Malberg, Encarnación: CFT I 405-13 (bibliogr.); P. W. Scheele, Die Fleischwerdung des Wortes. Biblische Explication und theologische Implikationen: «Kirche und Bibel» (Fs. E. Schick), Paderborn 1979, 357-69.

1. 1Tim 3,$16 ; \operatorname{Rm} 1,3 ; 8,3 ;$ Gál 4,$4 ; \operatorname{Rm} 9,5$. 
carne» ${ }^{2}$. Y esa confesión evoca en el prólogo a su evangelio el cuarto Evangelista. En efecto, el pre-joanneo himno cristiano al Logos divino ${ }^{3}$ alcanza en la redacción actual «su punto culminante» ${ }^{4}$ con la mayestática confesión o autotestimonio del Evangelista:

«Y la Palabra se hizo carne y acampó entre nosotros;

$y$ hemos visto su gloria, que recibe del Padre como Unigénito, lleno de gracia y de verdad» $(\mathrm{Jn} 1,14)$.

Así explica $[=\langle y »]$ san Juan la manifestación de «Quien... por Dios fue engendrado» $(\mathrm{Jn} 1,13)$ en la carne (Cf. infra). Y lo hace, formulando el triple descenso o acercamiento humano de «la Palabra» divina. La que «existía en el principio» eterno «y estaba con Dios y era Dios» (Jn 1,1), sin dejar de ser lo que antes era «se hizo» ahora lo que antes no era: iTemporal y creatura! ${ }^{5}$. Así la eternidad se ecercó al tiempo sin dejar de ser eterna, y el Creador se acercó a la creatura sin dejar de ser Creador. El primer descenso del Logos eterno y divino consistió, pues, en temporalizarse y creaturizarse. Y el Evangelista precisa seguidamente cómo: Haciéndose «carne» visible y palpable o asumiendo la plena humanidad - ia todo el hombre! - en la fragilidad de su existencia humana ${ }^{6}$. El segundo descenso humano del Logos divino fue, pues, humanizarse o devenir hombre perfecto. Lo hizo, por lo demás, no exclusivamente en el principal y más noble -el espíritu- constitutivo humano, sino en lo más perecedero y frágil - la carne - del hombre, asemejándose así «en todo a sus hermanos» los hombres, «con la excepción del pecado» ${ }^{7}$. La encarnación fue, pues, el acto epifánico y redentor, por el que el Logos divino se manifestó a los hombres como Dios-en-la-carne - ¡Dios humanizado! - y asumió nuestra naturaleza para elevarla al consorcio de la persona del Hijo unigénito, siendo por ello la encarnación de Dios «el caso irrepetiblemente supremo de la realización esencial de la naturaleza humana» ${ }^{8}$ : ¡La humanización de Dios inauguró la divinización del hombre! En la persona del Logos encarnado, en efecto, se realizó un divino intercambio o «admirable comercio» (San León M.) entre Dios y el hombre, pues Aquél «nos otorgó su deidad haciéndose hombre, para hacer a los hombres Dios» ${ }^{9}$. ¡Irrepetiblemente supremo ascenso del hombre! ¡Irrepetiblemente ínfimo descenso de Dios! Y, sin embargo, el descenso del Logos divino tocó su fondo en el hecho de «acampar entre noso-

2. 1 Jn 4,$2 ; 2 J n$ 7. 3. Cf. R. Schnackenburg, o.c., 200-207: trad. españ., 244-52 (bibliogr.); R.E. Brown, o.c., 21-23 (trad. españ., 196-98). 4. R. Schnackenburg, o.c., 241 (trad.españ., 282); así también S. Panimolle, Lettura pastorale del Vangelo di Giovanni, I, Bologna 1978, 30-34: 32. 5. El mismo verbo [ = egéneto] usan los LXX en el relato de la creación en el tiempo - por la eficaz palabra de Dios - tanto de los seres (Gén 1,3.6.9.20.24.30) como del hombre: Gén 2,4.6. 6. Cf. 1Jn 1,1; Jn 17,2; 3,6; 6,63. Así con: M.- E. Boismard, o.c., 67; R. Schnackenburg, o.c., 242s (trad. españ., 283s); Id., art. cit., 23; A. Feuillet, o.c., 98s. 7. Hebr 2,17; 4,15; Cf. Fil 2,7; Jn 8,46. 8. K. Rahner, o.c. [=ET], 145; Cf. también Id., Curso fundamental..., 259. 9. Sto. Tomás A., o.c.: supra 399; Id., Opusc. 57: In festo Corporis Christi, lect. 1. La encarnación es «la suprema comunicación de Dios al hombre»: K. Rahner, art. cit. [= SM II], 551 . 
tros», como Dios había ordenado construir el tabernáculo para «acampar» en Israel y prometió después «acampar» salvíficamente en Sión ${ }^{10}$ : Aquél no «habita» o se instala en casa fija, sino «mora en la tienda» de la carne asumida o «acampa» como peregrino en la humanidad, - «entre nosotros»-, siendo en efecto su «cuerpo» como el nuevo «templo» ${ }^{11}$ donde acampa Dios, para hablar y actuar salvíficamente «entre» los hombres. Quienes, en efecto, lo «vieron» y «contemplaron» encarnado, «vieron su gloria» o la manifestación de su divina potencia salvífica ${ }^{12}$, recibida «del Padre como Unigénito lleno de gracia y de verdad»: ¡Repleto de la total revelación salvífica de Dios al mundo! ${ }^{13}$.

2) La encarnación fue, pues, un triple descenso del Logos divino al mundo de los hombres, por el que «se hizo» temporal y creatura mediante la «carne» humana, mediante la cual «acampó entre» aquéllos para ser visto por ellos en la plenitud de la revelación salvífica de Dios. Nada de extraño, por tanto, si el Jesús joanneo menciona reiteradamente luego su descenso celeste, identificándose con «el pan vivo bajado del cielo» ${ }^{14} \mathrm{y}$ precisando la finalidad de aquel descenso: «Para hacer... la voluntad de quien me ha enviado» ${ }^{15}$. El descenso del Unigénito de Dios tuvo, pues, ante todo la finalidad servicial de cumplir la voluntad del Padre, haciendo incluso de esto su verdadero alimento ${ }^{16}$, siendo por tanto la encarnación el descenso del Logos para servir a Quien le envió: ¡El Hijo de Dios se encarnó, para devenir filial Siervo del Padre! Análoga concepción refleja un antiguo himno cristiano (Fil 2,6-11) ${ }^{17}$ : Quien «era de condición divina» o existía «como Dios» mismo «se vació» ${ }^{18}$, por decirlo así, de su divinidad haciéndose hombre ${ }^{19}$, pues «tomó la condición de siervo, haciéndose semejante a los hombres y apareciendo en su porte como hombre» (v. 7), humillándose asimismo en la obediencia «hasta la muerte y muerte de cruz» (v. 8): Así subraya el poeta cristiano la condición servicial de Cristo y su obediente autohumillación, hecha posible con su plena encarnación (v. 7c) y verdadera humanización (v. 7d) ${ }^{20}$. La encarnación — «dogma fundamental del cristianismo» ${ }^{21}$ - fue, pues, el acto por el que el

10. El verbo «acampar» es usado por los LXX en: Éx 25,8-9; J1 4,17; Zac 2,14; Cf. 8,3; Eclo 24,8. 11. Cf. Jn $2,19-21$ 12. 1 Jn 1,$1 ;$ Jn 1,14 b; Cf. 2,$11 ; 11 ; 40-43 ; 12,28 ; 17,5$ 13. Cf. I. de la Potterie, La verité dans saint Jean, I (AB 73), Rome 1977, 176-210; R. Schnackenburg, art. cit., 26. 14. Jn 6,51; Cf. 6,33.38.41.50.58: ¿En la Eucaristía descendió a su fondo más ínfimo el Logos de Dios! 15. Jn 6,38. 16. Cf. Jn 4,34;5,30;8,29. 17. Cf. L. Cerfaux, L'hymne au Christ-Serviteur de Dieu (Phil. 2,6-11): «Recueil L. Cerfaux», II, Gembloux 1954, 425-37; Le Christ..., 129-30. 283-98; P. Henry, art. cit., 7-38; J. Gnilka, o.c., 111-47; J. T. Sanders, The NT christological hymns, Cambridge 1971, 58-74; J. Heriban, Retto «froneîn»e «kénosis», Roma 1983 (último estudio monográfico, con nutrida bibliografía críticamente valorada). 18. Eso significa ekénosen (v. 7a): Cf. 1Cor 1,17; 9,15;2Cor 9,3; Rm 4,14. 19. El himno prescinde naturalmente del problema dogmático sobre la unidad de las dos naturalezas en la persona divina de Cristo, afirmando sólo —en lenguaje hímnico- la encarnación de Dios: Cf J. Gnilka, o.c., 118; así también L. Cerfaux, o.c. [=Recueil], 428; P. Henry, art. cit., 29. 20. Cf. L. Cerfaux, o.c., 428s; P. Henry, art. cit., 30s; J. Gnilka, o.c., 121s. 21. K. Rahner, Curso fundamental, 262; así también F. Malberg, art. cit., 405 («misterio central de la revelación» cristiana). 
pre-existente Hijo de Dios descendió de su condición divina y se anonadó como Dios haciéndose hombre, para autohumillarse en la forma de Siervo fiel u obediente hasta la ignominiosa muerte de cruz ${ }^{22}$. Y al proponernos Pablo como modelo - «itened los mismos sentimientos que tuvo Cristo!»- ese anonadamiento servicial del Hijo de Dios encarnado, nos trazó la única senda que debe seguir todo cristiano: Sirviendo fielmente al Padre hasta el final de la cruz, encarnarse en la vida de los hombres o hacerse uno de ellos y entrar en su mundo, para comunicarles la redención inaugurada por la encarnación de Cristo.

3) La eterna y divina «Palabra», en efecto, «vino a este mundo» de los hombres y «estuvo en el mundo hecho por Ella» ${ }^{23}$, por amorosa iniciativa del «Dios que amó tanto al mundo que le entregó a su Hijo único» o lo «envió al mundo» y lo «introdujo en el universo» ${ }^{24}$ humano. Así el Hijo de Dios, tras «salir del Padre» o «descender del cielo» ${ }^{25}$, como «Mesías en la carne» ${ }^{26} \mathrm{O}$ Salvador del hombre «vino a los suyos» en propiedad o «al mundo» ${ }^{27}$ de los hombres, -oscurecido entonces por «las tinieblas» de sus «obras malas» ${ }^{28}-$, y por algún tiempo «estuvo en el mundo» ${ }^{29}$. La encarnación del Logos o su venida al mundo [= «saeculum»] fue, pues, «la secularización del Hijo de Dios» ${ }^{30}$. Lo que implicó consecuencias cósmicas. Pues con ello inauguró Cristo «la re-secularización del mundo» o su re-orientación a Dios bajo el subordinado y vicario señorío del hombre ${ }^{31}$, tras la caída - por el pecadode su prístina sumisión al hombre y orientación a Dios, es decir, de su «secularización original» ${ }^{32}$. El Hijo de Dios, en efecto, «vino al mundo para hacer la voluntad del Padre» ${ }^{33}$ o devenir filial Siervo suyo ${ }^{34}$, inaugurando con ello en su misma persona el reinado de Dios sobre el mundo, que por el pecado había rechazado el hombre: La encarnacional secularización del Logos, sometido a la voluntad del supremo Señor del mundo, re-orientó éste nuevamente a Dios e inauguró así la «nueva creación» de un mundo devenido lo que antes del pecado era: Reino de Dios ${ }^{35}$. ¡Para eso se encarnó!

4) El Logos encarnado, efectivamente, se secularizó no para devenir

22. Con razón, por tanto, muchos Padres de la Iglesia explican la encarnación a la luz de Fil 2,6-8: Atanasio, Cirilo A., Teodoro M., Juan Cris., Hilario, Agustín, León M. (Cf. supra). 23. Jn $1,9-10 ;$ Cf. 3,$19 ; 16,28$. 24. Jn $3,16-17 ; 10,36 ; 17,18 ; 1$ Jn 4,9; Gál 4,4; Hebr 1,6. 25. Jn 16,$28 ; 6,33.41 .50 .58$. 26. $1 \mathrm{Jn} 4,2 ; 2 \mathrm{Jn} 7$. 27. Jn $1,1.9 .11 ; 3,16-17.19 ; 12,46$; 16,28. 28. Jn $3,19-20$; Cf. 8,$12 ; 12,35.46$ 29. Jn 9,5 ; Cf. 14,$19 ; 16,28 ; 17,11$ 30. S. Sabugal, ¿Liberación y secularización?: Intento de una respuesta bíblica, Barcelona 1978, 352. 31. Cf. Id., o.c., 351-54: Nuestros análisis prolongan, a este respecto, los de F. Gogarten y K. Rahner (Cf. Ib., 339-42) así como la enseñanza del reciente Magisterio de la Iglesia (Cf. Ib., 342-48). A este respecto, Cf. también: J. Auer, Weltoffener Christ, Düsseldorf ${ }^{2} 1963$; R. Guardini, Mundo y persona, Madrid 21967, 45-52.144-51; H. Urs von Balthasar, El problema de Dios en el hombre actual, Madrid ${ }^{2}$ 1966, 110-25.143-45; K. Rahner, El cristiano en el mundo que le rodea: ET VII (Madrid 1969) 110-12; Id., Theologische Rexionen zum Problem der Säkularisierung: STh VIII (Einsiedeln 1967) 637-66; Theologische Überlegungen über Säkularisation und Atheismus: STh IX (Einsiedeln 1970) 177-96. 32. Cf. S. Sabugal, o.c., 349-51. 33. Jn 6,38; Hebr 10,5.7. 34. Cf. supra 408. 35. Por eso la encarnación es como el «culmen y centro de la divinización del mundo»: K. Rahner, a.c. [SM II], 566. 
«mundo» entenebrado e identificarse con él o secularismarse: Quien «no conoció el pecado» ni lo «cometió» y sí estuvo exento de él ${ }^{36}$, tampoco fue «de este mundo» ${ }^{37}$. Su encarnacional secularización o venida al mundo, por el contrario, tuvo lugar «por nosotros» o «por nuestra salvación» como muchos antiguos Símbolos confiesan ${ }^{38}$. En fidelidad, por lo demás, a la soteriología encarnacional de los teólogos neotestamentarios, unánimes en subrayar la finalidad tanto epifánica como redentora de la encarnación o venida al mundo del Hijo de Dios:

a) El Logos encarnado y secularizado, en efecto, es «La luz verdadera» de los hombres o «la luz del mundo» ${ }^{39}$, es decir, la personificada epifanía de «la vida» divina o del «amor» que «Dios es» y con el que «tanto amó al mundo» pecador ${ }^{40}$. Ya por su encarnación es, pues, Cristo signo epifánico del gratuito amor de Dios al mundo entenebrado, sacramento primordial de la misericordia del Padre con los pecadores ${ }^{41}$. De ahí la finalidad epifánica de su secularización: Vino «al mundo, para que todo el que crea en Él -personificado amor de Dios al mundo- no siga en las tinieblas») del pecado fundamental -el odio- ni «camine en la oscuridad» del mismo, «sino tenga la luz de la vida» ${ }^{42}$, conferida por aquel amor del Padre, cuyo nombre manifestó Él «a los hombres» ${ }^{43}$. Con razón, por tanto, los Padres de la Iglesia y demás autorizados comentaristas del Símbolo subrayan esa finalidad epifánica de la encarnación: «Por el grandísimo amor a la creatura aceptó ser engendrado de la Virgen y unió mediante Sí el hombre a Dios» (San Ireneo), pues «el Logos se hizo carne por amor de quienes estaban apegados a la carne» (Orígenes), siendo «nuestra transgresión la que provocó el amor al hombre del Logos», el cual «se manifestó a causa de su amor por nosotros» (San Atanasio), revelando en su encarnación «la altura de la bondad y amor de Dios a los hombres» (San Basilio), pues «el amor a la humanidad» fue «el motivo de la presencia de Dios en» ella (San Gregorio Nis.), siendo por tanto la encarnación «un misterio de misericordia» (San León M.), ya que al «encarnarse por nosotros y por nuestra salvación» manifestó Cristo «mejor el amor de Dios para con nosotros» (Sto. Tomás A.), pues «el misterio de la encarnación revela el inmenso amor de Dios a los hombres» (Cat. Romano), y también «nos re-

36. 2 Cor 5,$21 ; 1 \mathrm{Pe} 2,22 ;$ Jn 8,$46 ; 1 \mathrm{Jn} 3,5 ; \mathrm{Hebr} 4,15$. 37. Jn 8,$23 ; 17,14.16$. 38. Cf. supra, 336. A este respecto, Cf. I. Ortiz de Urbina, o.c., 225-233; W. Beinert, o.c., 84-88. 39. Jn 1,9; 3,19; 8,12; 9,5; 12,46; Cf. IJn 2,8; Ef 5,14; Lc 1,78-79; Mt 4,16. 40. 1 Jn $1,2.7+4,8.16 ; 4,9-11 ;$ Jn 3,16 . En el «cuando» histórico de la encarnación y nacimiento de Cristo (Cf. Gál 4,4) «se manifestó la bondad de Dios y su amor a los hombres» (Tit 3,4): Cf. C. Spicq, Les Épîtres Pastorales, Paris 1947, 275; a este respecto, Cf. también Id., Agape, III, Paris 1959, 17-24. 41. Así con J. Alfaro, o.c., 121-25.132s; Cf. también: K. Rahner, Kirche und Sakramente (QD 10), Freiburg 1960, 14-17 (trad. españ., Barcelona 1964, 14-19); P. Smulders, La Chiesa sacramento di salvezza: «La Chiesa del Vaticano II» (ed. G. Barauna), Roma 1965, 36386: 377-79; E. Schillebeeckx, Cristo, sacramento del encuentro con Dios, Pamplona ${ }^{6} 1971$; R. Latourelle, Cristo y la Iglesia signos de salvación, Salamanca 1971, 16-19.93-127. 42. In 12,$46 ; 8,12 ; 1 \mathrm{Jn} 2,8-11 ;$ Cf. Jn 3,19-21; 11,9-10;1Jn 1,6-7; Ef 5,8.14; Col 1,13. 43. Jn 17,6.26; Cf. 14,7-11; Mt 11,25-27=Lc 10,21-22. 
vela que Dios es amor» (Conc. Vat. II) ${ }^{44}$. No hay duda: Como Dios humanizado y secularizado es Cristo signo eficaz de «la luz» o sacramento del gratuito y universal amor del Padre a los hombres, teniendo por tanto la encarnación y secularización del Hijo de Dios la epifánica finalidad de manifestar al mundo la misericordia o el amor, que Dios es y con el que ama a los pecadores. Complementaria de ésa es asimismo:

b) La finalidad redentora de la encarnación y secularización del Logos. En virtud de éstas, en efecto, es Cristo la personificada revelación de «la vida» divina ${ }^{45}$ y de «la salvación» de Dios ${ }^{46}$, cuyo universal designio salvífico se manifestó en Él de modo culminante y total ${ }^{47}$, siendo por ello signo eficaz o sacramento primordial de la salvación universal de Dios ${ }^{48}$. De ahí la motivación redentora de la encarnación y venida al mundo del Hijo de Dios, sintetizada por los teólogos neotestamentarios en vivificar y salvar al mundo, así como librar del temor a la muerte a cuantos por él eran esclavos. Aquél, en efecto, «es la Vida» (Cf. supra), que «bajó del cielo y vivifica al mundo» ${ }^{49} \mathrm{de} \mathrm{los}$ hombres, pues «vino para que tengan vida en abundancia» o, mediante la fe en Él, participen aquí ya de «la vida eterna» ${ }^{50}$. ¿Y se salven! Ya el mismo nombre «Jesús», impuesto por José al Hijo de María, traduce la específica misión de «salvar a su pueblo de sus pecados» ${ }^{51}$, personificando Él por ello «la salvación» de Dios o «la bondad de Dios nuestro salvador» ${ }^{52}$. De lo que Jesús tuvo clara conciencia, asegurando haber «venido a llamar... a los pecadores» $\mathrm{y}$ « $a$ salvar lo que estaba perdido» por el pecado ${ }^{53}$. En efecto, «Cristo Jesús vino al mundo a salvar a los pecadores» y «se manifestó para quitar el pecado» o «para deshacer las obras del diablo», pues «Dios envió a su Hijo al mundo... para que se salve por medio de Él» ${ }^{54}$, participando asimismo éste «de la carne y la sangre» o encarnándose, «para aniquilar mediante la muerte al señor de la muerte, es decir, al diablo, y libertar a cuantos -por temor a la muerte- estaban de por vida sometidos a esclavitud», pues Cristo «se manifestó... en la plenitud de los tiempos, para destruir el pecado mediante el sacrificio de sí mismo» ${ }^{54 a}$. No hay duda: La encarnación y secularización del Logos tuvo la finalidad redentora de vivificar a los «muertos» por el pecado, salvar a los «perdidos» por él, y librarlos de la «esclavitud» ocasionada por el temor a la muerte. Así lo subrayan bellamente también los Padres de la Iglesia e ilustres comentaristas del Símbolo: El Logos «se encarnó por nuestra salvación» y se hizo hombre «para reconducir el hombre a Dios» o «para que recibiéramos la filiación adoptiva» (San Ireneo), pues «asumió la carne... para re-

44. Cf. supra, 338-405 (passim). 45. Cf. Jn 1,4;11,25;14,6;1Jn 1,1-2; 5,11. 46. Lc 2,30; Cf. Tit 2,11;3,4-5. 47. Cf. Conc. Vat. II, Const. DV 2.4. 48. Subrayado por J. Alfaro (o.c., 132s) y los autores citados: Supra, n. 41. 49. Jn 6,33.48.50-51.58.63; Cf. 1Jn 5,11-12; Rm 8,2; Col 3,4. 50. Jn 10,$10 ; 3,16.36 ; 5,24 ; 6,39.47-51.63 ; 11,25-26 ; 1 \mathrm{Jn} 2,25$; 5,11-12. 51. Mt 1,21.25: Cf. supra, 317-20. 52. Lc 2,30; Tit 3,4. 53. Mc 2,17par; Lc 19,10. A este respecto, Cf. S. Sabugal, Abbá... La Oración del Señor, Madrid 1985, 636-64; Id., Pecado y reconciliación en el mensaje de Jesús, Palermo 1985, 636-69. 54. 1Tim 1,15; 1Jn 3,5.8; Jn 3,17. 54a. Hebr 2,14-15; 9,26. 
formarla» (Tertuliano) y "se revistió del hombre para llevarlo al Padre», quien «envió a su Hijo para que los redimiese» (San Cipriano), enviando «al buen Pastor para salvar a la grey de los hombres» (San Clemente A.), ya que Cristo «vino como Salvador de todos los hombres», a quienes se manifestó «para salvación del género humano» (Orígenes); pues «nosotros fuimos el motivo de la encarnación», ya que «por nuestra salvación amó Él tanto al hombre, que nació... en un cuerpo humano» y «se hizo hombre para que nosotros deviniésemos Dios» (San Atanasio), asumiendo «la carne para realizar el designio salvífico» (San Cirilo A.) o «para matar a la muerte oculta en» ella (San Basilio) y «para santificar al hombre por medio de sí mismo» (San Gregorio Nac.); Él, en efecto, «vino para salvarnos» (San Cirilo J.) o «para salvar a los hombres» (Teodoro M.), haciéndose «Hijo del hombre... para hacer que los hombres deviniesen hijos de Dios» (San Juan Cr.), y haciéndose «carne... para que... la carne se elevase hasta Dios-Verbo», pues «para salvación del género humano el Hijo de Dios nació de María y del Espíritu Santo» (San Hilario), tomando «nuestra carne a fin de redimirnos» (San Ambrosio) y haciéndose «hombre para poder salvar al hombre» (Nicetas R.); el Hijo de Dios, efectivamente, asumió a «todo el hombre... por nuestra salud espiritual», pues «se anonadó y tomó la forma de siervo para buscar y salvar lo que estaba perdido», dignándose «tomar un cuerpo para nuestra salvación» y queriendo «nacer para la salvación de los hombres», no desdeñando el Señor «revestirse de la naturaleza de siervo para el bien de los siervos», y sí decidiendo «el Dios inmenso... hacerse... humilde para sanar a los soberbios» (San Agustín); necesitó, pues, «nuestra redención que el unigénito de Dios se hiciese hombre», ya que «vino a sanar la naturaleza [humana] enferma por el pecado» (San Máximo T.), asumiendo aquélla «para reconciliarla con su Autor» y haciéndose «hombre para librar a los hombres de la muerte eterna», pues «el Señor se encarnó para restituir la salvación al género humano» (San León M.); sí, «Dios se hizo hombre por ti» (San Gregorio M.) o, más exactamente, «por nosotros y por nuestra salvación» (Sto. Tomás A.), pues el Padre envió «a su Hijo en nuestra carne a fin de por Él arrancar a los hombres del poder de... satanás y, en Él, reconciliar consigo al mundo», ya que se encarnó «para hacer a los hombres partícipes de la naturaleza divina» (Conc. Vat. II) ${ }^{55}$. Es, pues, claro:

55. Cf. supra, 338-405 (passim); otros testimonios patrísticos, al respecto, ofrecen: I. Ortiz de Urbina, o.c., 229-33; H. Urs von Balthasar, Encarnación y Pasión: MS III 2, 143-68: 150-52. Esa finalidad redentora de la Encarnación, subrayada por los Padres y, de modo especial por Orígenes (supra; In Num. Hom. 10,2: «Si no hubiese existido el pecado, no habría sido necesario que el Hijo de Dios se hiciese Cordero ni se encarnase») y por San Agustín (supra; Serm. 174,2: «Si el hombre no hubiese perecido, el Hijo del hombre no habría venido»), es re-afirmada también por ilustres teólogos posteriores, entre los cuales Sto. Tomás A. (supra; Suma Theol., III 1,3; In Sent. III $1,1,3)$ y San Buenaventura In Sent. III 1,2,3). No tiene fundamento bíblico, en nuestra opinión, la teoría de Dụns Escoto y otros teólogos, según los cuales Cristo se habría encarnado, aunque Adán no hubiese pecado; Cf. a este respecto: A. Spindeler, Cur Verbum caro factum?, Pa- 
Porque «Jesús» o el Salvador personifica «la vida» y «la salvación» de Dios como plenitud o culmen de su revelación, el Logos encarnado y secularizado es el personal signo eficaz o sacramento del universal designio salvífico del $\mathrm{Pa}$ dre, teniendo por tanto la encarnación y secularización del Hijo la finalidad redentora de vivificar y salvar a los muertos y perdidos por el pecado.

c) Una finalidad epifánica y redentora, por lo demás, prolongada en la Iglesia. «El Cuerpo místico de Cristo», en efecto, «se asemeja ...al misterio del Verbo encarnado», pues «como la naturaleza [humana] asumida sirve al Verbo divino de instrumento» salvador, «así la articulación social de la Iglesia sirve al Espíritu Santo... para el acrecentamiento de su cuerpo" ${ }^{56}$. De ahí que, como el Logos encarnado se secularizó (Cf. supra), también la Iglesia fue enviada por Cristo «al mundo» [= saeculum] y «está en» él o se seculariza y, así, dialoga con el mundo ${ }^{56 a}$. ¡No para configurarse con él! En su secularización, en efecto, debe aquélla soslayar el fácil riesgo de devenir «mundo» empecatado e identificarse con él o secularismarse ${ }^{57}$. Pues el discípulo de Cristo nunca debe olvidar y sí recordar siempre que el mundo, por «yacer todo él bajo el poder del maligno» y estar dominado por «las concupiscencias» de sus principales ídolos ${ }^{58}$, no es ya el mundo creado por Dios «bueno» y «muy bueno» ${ }^{59}$, sino «este mundo» malo y «perverso» ${ }^{60}$, pues «ama más las tinieblas que la luz» $\mathrm{y}$, por ello precisamente, «odia» tanto a Jesús como a sus discípulos ${ }^{61}$, autoexcluyéndose así de la intercesora plegaria de Aquél - «no ruego por el mundo»-y no debiendo ser amado - «no améis al mundo»-por quienes ${ }^{62}$, «sacados del mundo» y «no siendo de» él, tampoco «deben acomodarse a este mundo» ${ }^{63}$. En efecto, "como el alma mora en el cuerpo sin ser del cuerpo, así los cristianos habitan en el mundo pero no son del mundo» ${ }^{64} \mathrm{ni}$, por tanto,

derborn 1938, espec., 13-38; J. Solano, De Verbo Incarnato: «Sacrae Theologiae Summa», III, Madrid ${ }^{4} 1961,14-24$ (fuentes + bibliogr.); W. Dettloff, Redención: CFT II 484-99: 497ss (bibliogr.). 56. Conc. Vat. II, Const. LG 8. La expresión conciliar «se asemeja» [assimilatur] evita el error de afirmar que la Iglesia prolonga la encarnación del Logos, pues a) su constitutivo humano y divino no son dos naturalezas, b) ni aquéllos están hipostáticamente unidos c) en una presunta persona de la Iglesia; Cf. a este respecto: Y.M.-Congar, Dogme christologique et Ecclesiologie. Verité et limites d'un parallèle: «Das Konzil von Chalkedon» (ed. A. Grillmeier-H. Bacht), III, Würzburg 1954, 239-68: 252ss; Th. Sartory, Die Gefahr der Kategorie des «Inkarnatorischen» für die Ekklesiologie: «Ich glaube eine heilige Kirche» (Fs. D.H. Asmussen), Stuttgart 1963, 64-79; H. Mühlen, Una mystica Persona, München 1964, 172-75 (trad. españ., Salamanca 1974, 224-28); A. Grillmeier, Dogmatische Konstitution über die Kirke, I: LThK Ibis (1966) 15676: 171-174; J. Collantes, La Iglesia de la Palabra, I, Madrid 1972, 446-49. 56a. Jn 17,18; 20,21; Mc 16,15; Jn 17,11a. 17a; Cf. S. Sabugal, Liberación..., 354-56. Sobre el diálogo de la Iglesia con el mundo, Cf. infra, n. 76 (fuentes + bibliogr.). 57. Cf. S. Sabugal, Liberación..., 356-58; así también J. Ratzinger, El nuevo Pueblo de Dios, Barcelona 1972, 313-33.346-53. 58. 1 Jn $5,19[=12,31 ; 16,11 ;$ Lc 4,6$] ; 2,16-17$; Cf. Mt $6,24=$ Lc 16,13 . 59. Cf. Gén 1,4.10.12.18.21.25.31; 1 Tim 4,4. 60. Jn 12,31; 16,11; Gál 1,4; Rom 12,2; Cf. 1Cor 1,20; $2,6.8 .12 ; 3,18 ; 7,31 ;$ Ef 2,$2 ; \operatorname{Col} 2,20$. 61. Jn 3,19; $15,18-19.23-25 ; 17,14 ; 1 \mathrm{Jn} 3,13$. 62. Jn 17,9; 1Jn 2,15 + Sant 4,4, 63. Jn 17,6a.14b.16a (Cf. 15,19); Rm 12,2. 64. ¡Bella expresión de un antiguo autor cristiano!: Anónimo (s. II d. C.), Discurso a Diogneto, VI 3. 
deben secularismarse. Se lo veda ya la misma constitución divina de la Iglesia, semejante a la del Verbo encarnado (Cf. supra) y, en cuanto tal, constituida como «sacramento universal de salvación» ${ }^{65}$ o epifánico signo eficaz del salvífico amor de Dios al mundo. «La luz del mundo», en efecto, es Cristo ${ }^{66} \mathrm{y}$ la Iglesia ${ }^{67}$, por Él instituida «para ser comunión... de caridad» en el mundo e «instrumento suyo de redención universal», prolongando por ello la Iglesia en este mundo la obra epifánica y salvadora realizada por Cristo ${ }^{68} \mathrm{e}$ inaugurada con la encarnación (Cf. supra). En efecto, tras haber sido bautismalmente «iluminada» ${ }^{69}$ con «la luz» del «amor» que «Dios es»y «tiene» a los pecadores ${ }^{70}$, aquélla debe ser ahora epifanía de ese salvífico amor divino. Y lo hace, sobre todo, amando «a sus enemigos» ${ }^{71}$, para iluminar a «los hombres» con la «luz» de sus «buenas obras» concretizadas en aquel incondicional y gratuito «amor mutuo», que les manifiesta el incondicional y gratuito amor de Dios «al mundo» ${ }^{72}$ : ¡Así «da testimonio de la misericordia de Dios revelada en Cristo»! ${ }^{73}$. Pero la Iglesia es también «la sal de la tierra» y «la levadura de la masa» humana ${ }^{74}$, debiendo salarla y fermentarla con el salvífico anuncio de la redención universal de Cristo ${ }^{75}$. Precisamente para cumplir esa universal misión epifánica y salvadora dialoga la Iglesia con el mundo ${ }^{76}$, encarnándose en sus civilizaciones y culturas así como en sus instituciones y estructuras, no con el fin de mundanizarse o quedarse e instalarse en ellas, sino para evangelizarlas ${ }^{77}$ : ¡Iluminándolas con «la luz» del amor de Dios y redimiéndolas con «la salvación» de Cristo! Así, secularizada pero no secularismada, prolonga la Iglesia y cada cristiano la redención del mundo y de la historia humana, inaugurada ya con la encarnación del Hijo de Dios. ¿Cómo tuvo lugar ésta?

\section{El CÓMO DE LA ENCARNACIÓN}

Cf.: M. J.-LAGRANGe, Matthieu 8-18; Luc 25-40; J. SCHMID, Matthäus 3444 (trad.españ., 53-67); Lukas 39-50 (trad.españ., 58-72); O. SPINETOLI, Matteo, Assisi ${ }^{2}$ 1973, 28-47; R. FABRIS, Matteo, Roma 1982, 39-58; M.-J. GRUEN-

65. Conc. Vat. II, Const. LG 1.48; GS 45; Decr. AG 1.5. 66. In 8,12 etc. (Cf. supra, n. 39); Conc. Vat. II, Const. LG 1.3. 67. Mt 5,14-16 (Cf. Fil 2,15; Ef 5,8); Conc. Vat II, Const. LG 9; Decr. AA 6; AG 1.11. 68. Conc. Vat. II, Const. LG 9; SC 6-7. 69. Hebr 6,4; 10,32; Cf. Ef 5,14. 70. 1Jn 1,7+4,8-10; Cf. Jn 3,16-19. 71. Cf. Mt 5,44-48par; Rm 12,20; Conc. Vat. II, Const. GS 28. 72. Mt 5,16; Jn 13,34s; 17,21; 3,16; 1Jn 4,9-11. 73. Juan Pablo II, Enc. DM VII 12-14. 74. Mt 5,13;13,33 (=Lc 13,20s); Conc. Vat. II, Const. LG 9; Decr. AG 1. 75. Mc 16,15s; Mt 28,19s; Conc. Vat. II, Const. LG 9; Decr. AA 2.6; AG 1.5-7.10; Pablo VI, Exh. apost. EN 14-27.49-58. 76. Cf. Conc. Vat. II, Const. GS 21.28.40.92; ya Pablo VI, Enc. ES 72.91-106. A este respecto, Cf.: K. Rahner, Sobre el diálogo en la sociedad pluralística: ET VI (Madrid 1969) 45-57; Vom Dialog in der Kirche: STh VIII (Einsiedeln 1967) 426-44; E. Schillebeeckx, Dios y el hombre, Salamanca 1969, 245-72; J. Ratzinger, o.c., (supra, n. 57), 32428. 77. Cf. Pablo VI, Exh. apost. EN 20. 51; Conc. Vat. II, Const GS 40-90. 
THANER, María en el NT: «Mariología» (ed. J.B. Carol), Madrid 1964, 82-110: 85-93; W.J. BURGHARDT, María en la patrística occidental: Ib., 111-55: 119-37; PH. J. DONNELy, La virginidad perpetua de la Madre de Dios: Ib., 619-83: 62035; A. MÜLLER, o.c., 461-70; J. MICHL, Die Jungfrauengeburt im NT: MarSt 4 (1969) 145-84; C. Pozo, María..., 207-33; J. McHugh, La Madre de Jesús en el NT, Bilbao 1979, 90-122.218-35.328-51; S. MuÑOZ-IGLESIAS, La concepción virginal de Cristo en los Evangelios de la Infancia: EstB 37 (1978) 5-28.213-41; I. DE LA PotTERIE, La Mère de Jésus et la conception virginale du Fils de Dieu: Mar 40 (1978) 41-90; J. DE FREITAS FERREIRA, Conceiçao virginal de Jesus, Roma 1980; R.E. Brown, El nacimiento del Mesias, Madrid 1982, 51-163.295-341.54157 (bibliogr.); R. LAURENTIN, Les Évangiles de l'Enfance du Christ, Paris 1982 (passim); J. GALOT, Maria, la donna nell'opera di salvezza, Roma 1984, 91-183: $122-75$.

Al interrogante sobre el modo de la encarnación del Hijo de Dios, o su generación temporal y «venida en la carne» a este mundo, responden tres teólogos neotestamentarios, reasumiendo otras tantas tradiciones independientes de las primitivas comunidades cristianas:

\section{1) «Por Dios fue engendrado» $(\mathrm{Jn} 1,13){ }^{78}$}

Tras haber afirmado que «el Logos» divino y eterno «vino a los suyos pero no lo recibieron», precisa el evangelista que Aquél «dio la potestad de devenir hijos de Dios a cuantos lo recibieron» o «creen en su nombre ${ }^{79}$, Quien no de las sangres ni de un deseo carnal ni de un deseo viril, sino de Dios fue engendrado» ${ }^{80}$. Con ello se niega, en primer lugar, que la generación temporal

78. Cf.: M.-F. Braun, Qui ex Deo natus est (Jean 1,13): "Aux sources de la tradition chrétienne» (Mél. M. Goguel), Neuchâtel-Paris 1950,11-31; Id., La Mère des fidèles. Essai de théologie joannique, Tournai-Paris 1950, 33-38; J. Galot, Etre né de Dieu. Jean 1,13 (AB 37), Rome 1969; Id., Egli non fu generato dai sangui (Gv 1,13): Aspr 27 (1980) 153-60; Id., o.c., 127s; J. McHugh, o.c., 328-41; I. de la Potterie, a.c., 66ss; Id., María-Virgen en el Cuarto Evangelio, Madrid 1979, 35-64; Id., Il parto verginale del Verbo incarnato: «Non ex sanguinibus sed ex Deo natus est» (Gv 1,13): Mar 45 (1983) 127-74; P. Hofrichter, Nicht aus Blut sondern monogen aus Gott geboren (FB 31), Würzburg 1978; J. Winandy, La conception virginale dans le NT: NRTh 10 (1978) 706-19: 709-15; Note complementaire sur la conception virginale dans le NT: Ib., 104 (1982) 423-31: 428ss; A. Vicent, La doble generación de Jesucristo según Jn 1,13-14: EstB 40 (1982) 49-117. 79. Jn 1,11-12. 80. Jn 1,13. El sing. «él... fue engendrado» está asegurado por la crítica externa: Así lo atestiguan todos los Padres de la Iglesia hasta Tertuliano y varios después de él (Cf. F.-M.-Braun, a.c., 17-22; J. Galot, o.c., 11-49.54ss; P. Hofrichter, o.c., 25-28.6981.88-91; A. Vicent, a.c., 56-83), quien acusó a «los falsificadores del mismo» [=gnósticos valentinianos] haber cambiado el sing. «engendrado» de la tradición anterior por el pl. «engendrados» (Cf. supra, 345; J. Galot, o.c., 41-49; P. Hofrichter, o.c., 40-42; A. Vicent, a.c., 83-94), el cual está ciertamente en la línea de la teología joannea sobre «los creyentes en Jesús» como «nacidos de Dios» (Cf. Jn 3,3-8; 1Jn 3,9; 4,7; 5,1-4.18a), por lo que fue luego introducido en el texto joanneo por casi todos los papiros y manuscritos así como por las versiones antiguas y, a partir de san Clemente A., por muchos Padres de la Iglesia (Cf. J. Galot, o.c., 50-94; P. Hofrichter, o.c., 20-24.33-68; A. Vicent, a.c., 99-113), siendo aceptado el sing. «engendrado», sin embargo, por varios exegetas y teólogos a partir del s. XIX hasta el presente (Cf. I. de la Potterie, a.c. [Mar 
(Cf. infra) del Logos encarnado haya tenido lugar «de las sangres». ¡Una expresión extraña! No lo era, sin embargo, entonces. Se trata, en efecto, de un semitismo: El AT hebreo y griego [LXX] usa con frecuencia el «plural de composición», para designar los varios o múltiples componentes de una cosa ${ }^{81}$, usando por ello el pl. «sangres» para expresar su abundancia derramada en un asesinato ${ }^{82}$ o en los sacrificios ${ }^{83}$, así como la vertida por la mujer durante la menstruación y en el parto ${ }^{84}$. Enlazando con esta concepción veterotestamentaria y judaica, el mencionado texto joanneo niega por tanto que la generación de Jesús en «María, su madre» ${ }^{85}$ fuese precedida o acompañada por el abundante [ = «sangres»] derrame de sangre, normal en toda mujer antes de la generación [ = menstruación] y durante el parto: La concepción y nacimiento de Jesús fue virginal ${ }^{86}$. Una concepción virginal subrayada por la negación siguiente: «No de un deseo carnal», excluyendo así de aquella generación todo deseo - masculino y femenino- sexual o concupiscencia carnal. Y al añadir el evangelista que fue engendrado «no de un deseo viril», excluye de aquella concepción la pasión sexual de un hombre e, implícitamente, niega que Jesús haya tenido padre humano: Agente de su generación temporal no fue un hombre sino «de Dios fue engendrado» ${ }^{87}$. Así atestigua - con reiterada y expresiva formulación - san Juan el modo de la encarnación del Logos, hecho «carne» al ser virginalmente no sólo concebido [ = virginidad antes del parto] sino también dado a luz [ = virginidad en el parto] por «María su madre», y ser [en ella] «engendrado por Dios», su «propio Padre» (Jn 5,18), de quien por ello es aquél su «Unigénito» ${ }^{88}$. Antes que el cuarto evangelista, sin embargo, otros dos teólogos neotestamentarios atestiguaron también la fe de la Iglesia apostólica en la concepción virginal de Jesús, precisando ambos el Agente divino de la misma.

\section{2) Concebido por el Espíritu en María}

Los evangelistas Mateo y Lucas han narrado los hechos sustancialmente históricos sobre la concepción, el nacimiento y la infancia de Jesús ${ }^{89}$, según el

1978], 60s), entre los que se cuentan los autores citados (supra, n. 78; también: S. Sabugal, Christós, 439: R. Laurentin, o.c., 480s). También la crítica interna favorece la autenticidad del sing. «engendrado»: Cf. F.-M. Braun, o.c., 22-25; J. Galot, o.c., 95-106; I. de la Potterie, a.c., 65ss; Il parto verginale..., 131-63. 81. Cf. P. Joüon, Grammaire de l'Hebreu biblique, Rome ${ }^{2} 1947$, 415. 82. Cf. Gén 4,10; 1Sam 25,33; 2Sam 21,2; 2Re 9,7.26; Sal 51,14 (LXX=Los textos citados y: Jces 9,24; Ez 22,2; Hab 2,8; 1Mc 7,14; así también Apoc 16,6 [S]; 18,24: B). El asesino es, pues, «el hombre de sangres»=el sanguinario: 2Sam 16,7-8; Sal 26,9; 59,3; Eclo 34,21 $(\mathrm{LXX}=$ Los textos citados + Sal 54,23). 83. Sal 16,4 (LXX: 15,4). 84. Lev $20,18+\mathrm{Ez}$ 16,9.22 (=durante la menstruación); Lev 12,4-5.7 (= en el parto). Testimonios de la literatura judaica, al respe ${ }^{a}$ to, ofrece P. Hofrichter, o.c., 92-101; Cf. I. de La Potterie, a.c. [Mar 40], 73; Id., a.c. [Mar 45], 146s. 85. Jn 2,1.2.3.5.12; 19,25.26.27. 86. Así con I. de la Potterie, a.c. [Mar 40], 73-75 [=o.c., 51-53]; Id., a.c. [Mar 45], 146-50. Así fue interpretada la expresión «engendrado no de las sangres» por varios Padres de la Iglesia: Cf. Id., a.c. [Mar 45], 151-58. 87. Se trata, en efecto; de la generación temporal del Logos por Dios: Cf. I. de la Potterie, a.c. [Mar 40], 77-85; Id., a.c. [Mar 45], 131-39; P. Hoffrichter, o.c., 120-25. 88. Jn 1,14; Cf. supra, 327s. 89. Mt 1,18-2,23; Lc 1,26-2,40. 
género literario del judaico «midrash haggádico» sobre el nacimiento e infancia y vocación de importantes personajes - Isaac, Moisés, Gedeón, Sansón, Samuel- veterotestamentarios, en cuyos relatos el humanamente insuperable obstáculo para su concepción [= por madres estériles: Isaac, Sansón, Samuel] y vocación [ = Moisés y Gedeón] es superado por una especial intervención de Dios, quien así manifiesta ser Él el que toma la iniciativa y guía la historia de la salvación ${ }^{90}$ : Cuando, con la concepción y nacimiento del pre-anunciado Mesías, alcanza aquella su cénit, culmina también tanto el obstáculo humano como - y sobre todo- la intervención salvífica de Dios. Así lo subrayaron independientemente ambos evangelistas. Sus relatos, por lo demás, presuponen el derecho y praxis matrimonial judaico, según el cual «los esponsales» o mutuo consentimiento ante testigos, - por el que la novia devenía ya «esposa» del novio y era por ello castigada como adúltera en caso de infidelidad-, precedían al «matrimonio formal», realizado éste con una breve fórmula y previo el contrato matrimonial, -que aseguraba la manutención de la esposa por el esposo-, concluido con la transferencia de aquélla a la casa de éste ${ }^{91}$.

\section{a) « $j$ Lo engendrado en María es del Espíritu!»}

Así subraya san Mateo la generación divina de Jesús en María (Mt 1,21). Antes, sin embargo, el evangelista responde a la pregunta «¿quién es Jesús?» con su presentación genealógica como el mesiánico «descendiente de David» y «de Abraham» ${ }^{92}$, precisando ya en ese contexto que aquél fue «[divinamente] engendrado de María» ${ }^{93}$. Y seguidamente relata el verdadero origen de Jesús ${ }^{94}$, atestiguando que «la generación de Jesucristo» en «su madre María

90. Cf. a este respecto: S. Muñoz Iglesias, Los Evangelios de la Infancia y la infancia de los héroes: Est B 16 (1957) 5-36; El Evangelio de la Infancia en san Lucas y las infancias de los héroes bíblicos: Ib., 329-82; El género literario del Evangelio de la Infancia en san Mateo: Ib. 17 (1958) 243-73; R. Laurentin, Lc I-II, Paris 1957, 93-119 (=Lc); Id., o.c., 114-32 (= Lc); C. Perrot, Les récits d'enfance dans la Haggada antérieure au II ${ }^{e}$ siècle de notre ère: RSR 55 (1967) 481-518; O. Spinetoli, Introduzione ai Vangeli dell'Infanzia, Assisi ${ }^{2} 1970,28-50$ (=Mt). 95-115 (= Lc); A. Díez Macho, La historicidad de los Evangelios de la Infancia, Madrid 1977, 15-56; R. Brown, o.c., 567-69.581-87; K. Stock, Die Berufung Marias: Bib 61 (1980) 457-91: 458-65 (=Lc); L. Legrand, L'annonce à Marie (LD 106), Paris 1981, 89-140 (=Lc; el autor designa ese relato un «apocalipsis»: 127ss.) 91. Cf. M. Ket. I-XIII; Str.-Bill., I, 45-47; II 372-99; III 393-99; J. Jeremias, Jerusalem zur Zeit Jesu, Göttingen 1962, $401-5$ (trad. españ., Madrid 1977, 376-80); M.J. Gruenthaner, o.c., 85s. Ese derecho matrimonial judaico se enraiza, por lo demás, en la respectiva legislación veterotestamentaria: Cf. R. de Vaux, Instituciones del AT, Barcelona 1964, 55-73: 65-71; A. Tosato, Il matrimonio israelitico (AB 100), Roma 1982, 86-110. 92. Mt 1,1-17: Cf. M.D. Johnson, The purpose of the biblical genealogies (SocNTStMS 8), Cambridge 1969, 139228: 217-19; S. Sabugal, Christós, 67-71; R.E. Brown, o.c., 51-91 (bibliogr.); R. Laurentin, Les Évangiles, 314-19. 93. Mt 1,16b: La brusca sustitución del verbo activo, en el esquema genealógico «A engendró a $\mathrm{B}$ » (1,2-16a), por el pasivo [ = ¡sustituto del nombre divino!] «fue engendrado" $(1,16 \mathrm{~b})$, representado éste por los mejores y más antiguos manuscritos (Cf. M.-J. Lagrange, Matthieu 6-7; R.E. Brown, o.c., 56-58), anticipa ya veladamente la doble mención explícita de la «generación» de Jesús «en María por el Espíritu Santo» (1,18.20): Cf. S. Sabugal, Christós, 70, n. 16; A. Díez Macho, o.c., 72-73. 94. Mt 1,18-25; a este respecto, además de la bibliografía 
prometida de José, antes de cohabitar» y, por tanto, siendo aquélla virgen, tuvo lugar no por repudiable adulterio sino realizada «por el Espíritu Santo», haciéndolo en ella este Agente divino «para que se cumpliera» el inspirado oráculo profético sobre la «concepción» del «Emmanuel» por-«la Virgen» ${ }^{95}$. El humanamente insuperable obstáculo de la virginidad de María, para la generación del Mesías, fue superado así - como lo hizo Dios en la concepción de Isaac, Esaú y Jacob, José, Sansón y Samuel ${ }^{96}$ - por el influjo del Espíritu Santo, quien sustituyó -ipodía hacerlo! - la cooperación sexual de José y, con ello, mostró ser Dios el que llevó a su culmen la historia salvífica. En fidelidad, por lo demás, a la promesa hecha por Dios a David sobre la «permanencia eterna» de su «casa y reino» mediante «la descendencia» suya ${ }^{97}$. Eso, precisamente, subraya el mandato divino al «descendiente davídico» José ${ }^{98}, \mathrm{y}$ por éste seguidamente cumplido: Tomando «a María por su esposa» e imponiendo al Hijo de ésta «el nombre Jesús» ${ }^{99}$, los incardinaba en su genealogía davídica ${ }^{100}$. Así el Hijo de María y, en cuanto engendrado en ella por el Espíritu Santo, el «Hijo de Dios» devino «descendiente de David» y «de Abraham» ${ }^{101}$ por la línea genealógica de su padre legal José. Quien no tuvo rela-

indicada al inicio de este parágrafo, Cf.: K. Stendahl, Quis et unde. An analysis of Mt 1-2: «Judentum, Urchristentum, Kirche» (Fs. J. Jeremias), Berlín 1964, 94-105: 100-104; A. Vögtle, Die Genealogie Mt 1,2-16 und die matthäische Kindheitsgeschichte: BZ 8 (1964) 45-58.239-62; 9 (1965) 32-49; Id., Die matthäische Kindheitsgeschichte: «L'Évangile selon Matthieu» (ed. M. Didier), Gembloux 1972, 153-83; Ph. J. Donnely, o.c., 620-24; M. Kramer, Die Meschwerdung Jesu Christi nach Matthäus (Mt 1): Bibl 45 (1964) 1-50: 4-22; X. Léon-Dufour, Études d'Évangile, Paris 1965, 47-81: 65ss (trad. españ., Madrid 21982, 51-82: 67ss); E. Peretto, Ricerche su Mt 1-2, Roma 1970, 20-33; W. Trilling., Jésus Messie et fils de David (Mt 1,18-25): «L'annonce du Christ dans les Évangiles synoptiques», Paris 1971, 11-36; J.M. Graystone, Matthieu 1,18-25. Essai d'interpretation: RThPh 23 (1973) 221-32; C. Pozo, María, 229-33; R.E. Brown, o.c., 121-63 (bibliogr.: 163). 95. Mt 1,18-20.22-23. El oráculo de Is 7,14 es citado por Mt 1,23 no según el texto hebreo, - -según el cual Isaías anuncia al rey Acaz [ca. 734] la futura concepción natural y parto por su «joven» esposa (ha'almah) de «un hijo» [= Ezequías] o príncipe davídico, quien, liberando a Judá de sus enemigos siro-efraimíticos, sería «signo» personificado de la presencia salvífica de Dios con su Pueblo [ $«$ Emmanuel»]-, sino según el texto septuagintista (Cf. K. Stendahl, The School of St. Matthew, Lund 21967, 97-99; R.H. Grundry, The use of the OT in St. Matthew's Gospel [Suppl. NT 18], Leiden 1967, 89-91), según el cual «la virgen» (he parthénos) o «la» joven esposa [del monarca], pero «virgen» aún, "concebirá» de modo natural a «un hijo», resaltando así -más que en el caso de una «joven» ya encinta - el «signo» de la presencia salvífica de Dios con su Pueblo. Sobre Is 7,14 Cf.: E. May, María en el AT: «Mariología» (ed. J.B. Carol), 54-81: 65-68; R. Kilian, Die Verheissung Immanuels Jes 7,14 (SBS 35), Stuttgart 1968 (bibliogr.); G. del Olmo, La profecía de Emmanuel (Is 7,10-17). Estado actual de la interpretación: EphMar 22 (1972) 357-85; C. Pozo, o.c., 175-201 (bibliogr.); R.E. Brown, o.c., 143-53. 96. Cf. Gén 17,16-22+18,9-15+21,1-7 (=Isaac); 25,21-22 (=Esaú y Jacob); 30,22 (=José); Jces 13,2-7.24 (=Sansón); 1Sam 1,5-6.10-11.19-20.27 (=Samuel). La acción de Dios en esas mujeres estériles - Sara, Rebeca y Raquel, la madre de Sansón y Ana- «culmina con María»: J. Ratzinger, o.c., 227s (trad. españ., 241). 97. 2Sam 7,12.16=1Crón 17,11.14. 98. Mt 1,20b.21a.24-25. 99. Mt 1,20b; Cf. 1,6-16a. 100. Así con: K. Stendahl, a.c., 101s; A. Vögtle, a.c. [BZ 1964], 242-43.245; X. Léon-Dufour, o.c., 78s (trad. españ., 79s); S. Sabugal, o.c., 71; A Díez Macho, o.c., 59-64; R. E. Brown, o.c., 137s.; R. Laurentin, Les Évangiles, 319-23. 101. Mt 1,25a; $2,15 \mathrm{~b} ; 1,1$. 
ciones matrimoniales con María «hasta que» - ni después que- «dio a luz a su Hijo» (Mt 1,25b), permaneciendo por tanto aquélla virgen después del parto ${ }^{102}$ : La «madre» de Jesús, sexualmente intacta no sólo «antes de» la concepción sino también después de «darlo a luz», es sencillamente «la Virgen» ${ }^{103}$.

b) «¡El Espíritu Santo descenderá sobre ti...!»

San Lucas redactó el anuncio sobre la concepción de Jesús y vocación maternal de María en un relato (Lc 1,26-38) ${ }^{104}$ de innegable dramatismo literario ${ }^{105} \mathrm{y}$, por lo demás, claramente estructurado: Al proemio sobre la presentación tanto de los personajes - «el ángel Gabriel» y «la virgen María»como del escenario geográfico - Nazaret- del drama (vv. 26-28b), sigue la acción dramática de un diálogo entre el mensajero celeste y «la Virgen» nazaretana (vv. 28b-38b) en dos momentos: La primera fase anuncia el cumplimiento en María de la profetizada visita salvadora de Dios al Israel escatológi-

102. La construcción griega y semítica «hasta que» (heos hou) después de una negación no implica necesariamente el cese de lo negado tras el límite del «hasta que» (Cf. K. Beyer, Semytische Sintax im NT, I, Göttingen ${ }^{2} 1968,132$ s), y sí puede expresar su continuación tras este límite, como lo muestran varios textos del AT (LXX: Gén 8,7; 28,15; 2Sam 6,23; Is 46,4; Sal 71,7; 89,2; $109,1)$ y del NT (1Cor 15,25; Mt 22,44par; 28,20), frecuentemente - y con razón- aducidos a este respecto por los Padres de la Iglesia (Cf. J.M. Germano, «Et non cognoscebat eam donec...»: Mar 35 [1973] 184-240: 186-200). El evangelista Mateo, interesado en subrayar la virginidad de María antes del parto (Mt 1,16b.18b.20b), nada dice expresamente en 1,25 sobre su virginidad después del parto, «pero tampoco la niega absolutamente», como lo reconoce un comentarista protestante (P. Bonnard, L'Évangỉle selon saint Matthieu, Neuchâtel 1963,22: trad. españ., 38) con todos los autores católicos (Cf. M:-J. Lagrange, Matthieu 17s; A. Vögtle, Mt 1,25 und die Virginitas B.M. Virginis post partum: ThQ 147 [1967] 28-39; O. Spinetoli, Matteo 41-43; R.E. Brown, o.c., 130s; M. Mariano, Substrato arameo en el relato de la anunciación a José. II: «Et non cognoscebat eam donec peperit Filium» (Mt 1,25): EstB 38 [1979-80] 237-68; R. Fabris, o.c., 58 ; J. Galot, María, 177s), estando aquélla ciertamente implícita en el hecho de que los «hermanos» $y$ «hermanas» de Jesús mencionados por Mateo (Mt 12,46; 13,55s) son, en realidad, sus primos y, por tanto, no hijos de María: Cf. infra, 432s. 103. Mt 1,18.25.23. 104. Para su interpretación, además de la bibliografía indicada al inicio de este parágrafo y de los comentarios (M.-J. Lagrange, Luc 25-40; J. Schmid, Lukas 39-50: trad. españ., 58-72; H. Schürmann Lukas, I 39-64; O. Spinetoli, Luca 66-80), Cf.: A. Medebeille, Annontiation: DBS I 262-97; St. Lyonnet, Le récit de l'Annontiation et la Maternité divine de la Ste. Vierge: Ami Cler 66 (1956) 33-46; J.-P. Audet, L'annonce à Marie: RB 63 (1956) 346-74; S. Páramo, La anunciación de la Virgen: Est B 16 (1957) 161-85; R. Laurentin, Luc I-II, 23-79; Les Évangiles, 184-96; P. Benoit, L'Annontiation: «Exégèse et Théologie», III, Paris 1968, 197-215; Ph. J. Donnely, o.c., 624-35; E. Gössmann, Verkündigung Mariä: LthK X 713s; A. Müller, o.c., 458-70; P. Prete, Il racconto de l'Annunziazione di Lc 1,26-38: BibOr 15 (1973) 75-88; C. Pozo, María, 207-29; J. McHugh, o.c., 90122; P.E. Brown, o.c., 295-341 (bibliogr.: 340s); K. Stock, a.c., [supra, n. 90], 465ss; L. Legrand, o.c., 141-292. 105. Con razón detectado y valorado en sus múltiples representaciones por el arte (¡Fray Angélico!) y el drama (¡Paul Claudel!) cristianos; Cf. Anónimo, Anunciación: EUI V 879-89; H. Leclercq, Annontiation dans l'art: DACL I 2255-67; P. Toschi, Annunziazione: EC I 1382-96: 1385ss; E. Sauser, Verkündigung Mariä. III. Ikonographie: LThK X 714s (bibliogr.). 
co, mediante la concepción y nacimiento del Mesías davídico (vv. 28b-33), relatando en la segunda fase la realización de aquel anuncio por el Dios «a quien nada es imposible»y, por eso, superará el humanamente insuperable obstáculo de la virginidad de María, mediante la creadora y vivificante acción de su Espíritu en la que será madre siendo virgen, es decir, concibiendo virginalmente al mesiánico Hijo de Dios (vv. 34-38b); el desenlace de la acción dramática concluye todo el relato (v. 38c), literariamente así estructurado:

1. Próemio (vv. 26-28a)

2. Acción dramática: Diálogo (vv. 28b-38b)

1) $1 .{ }^{a}$ fase (vv. 28b-33)

2) $2 .^{a}$ fase (vv. 34-38b)
a) pregunta de María (v. 34)
b) respuesta del ángel (vv. 35-37)
c) sí de María (v. 38a-b)

3. Desenlace (v. 38c).

Esta estructura dramática del relato lucano sobre el anuncio de la concepción y nacimiento de Jesús, por lo demás, fue redactada por Lucas en un contrastante paralelismo con el previo relato sobre el anuncio de la concepción y nacimiento de Juan ${ }^{106}$, subrayando así -en tácita polémica antibaptista- la superioridad de Aquél sobre éste ${ }^{107}$ :

Anuncio a Zacarías (Lc 1,5-25)

-presentación de los padres (5-7)

-aparición del ángel: Templo (8-11)

-turbación de Zacarías (11)

- «iNo temas...!» (13a)

-anuncio del nac. de Juan (13b-17)

-obstáculo: «¿cómo sabré...?» (18)

-superación (v. 19)

-signo: Mudez (20a)

-silencio obligado de Zacarías (22)

-partida [«apélthen»] de Zacarías (23)
Anuncio a María (Lc 1,26-38)

-presentación de los padres (26-27)

-aparición del ángel: casa de María (28a)

-turbación de María (29)

- «iNo temas...!» (30)

- anuncio de la conc.-nac. de Jesús (31-33)

-obstáculo: «¿cómo será esto...?» (34)

-superación: Por «el Espíritu S.» (35-36)

- signo: Fecundidad de Isabel (37)

-Respuesta [«hágase»] de María (38a-b)

-partida [«apélthen»] del ángel (38c)

Ese paralelismo contrastante del anuncio a María refleja, pues, a la vez una estructura concéntrica, en la que el obstáculo formulado por aquélla constituye como el quicio de todo el relato y, por tanto, la clave para entender su significado teológico:

-El proemio del relato lucano encuadra el lugar de la acción dramática en «Nazaret», la bella ${ }^{108}$ pero insignificante aldea galilaica, hasta entonces ig-

106. Lc 1,5-25. 107. Cf. R. Laurentin, Lc. I-II, 23-42; P. Benoit, L'enfance de Jean Baptiste selon Luc I: «Exégèse et Théologie» III 165-96: 193ss; A. George, Le parallèle entre JeanBaptiste et Jésus en Lc 1-2: «Mél. B. Rigaux», Gembloux 1970, 147-71; L. Legrand, o.c., 67-83. 108. Ya un autor antiguo designó a Nazaret «la flor de la Galilea» (San Jerónimo, Ep. 
norada por la literatura veterotestamentaria y judaica: ;Allí, de donde «nada bueno podía salir» ${ }^{109}$, va a salir o nacer Quien «todo lo hizo bien» y por iniciativa del Dios que «sólo Él es bueno»! ${ }^{110}$. Pues esa iniciativa divina subraya Lucas, precisando que «Dios» envió a su «ángel Gabriel» ${ }^{111}$ con un mensaje para la joven nazaretana «María», nombre de «la virgen» aún pero ya «prometida» ${ }^{112} \mathrm{y}$, por tanto, legalmente esposa del davídico «José» ${ }^{113}$.

- La acción dramática del relato lucano se desarrolla en un animado diálogo entre el mensajero celeste y María, recorrido todo él por una finalidad muy concreta: Pedir a «la virgen» nazaretana su consciente y libre permiso, — isin el permiso de los siervos no quiere obrar el Señor! —, para la realización del designio divino sobre la concepción y nacimiento del Mesías:

La primera fase de aquel diálogo es introducida por el ángel $(\mathrm{Lc} 1,28)$ con el mismo saludo - «chaire»= ;alégrate! - dirigido por algunos profetas a la futura comunidad escatológica o al Israel mesiánico personificado en «la Hija de Sión», invitándole al regocijo ante la inminente venida salvadora de

46,13); y un moderno historiador hebreo subraya la «hermosura del lugar», cuya «vista desde la cima de la colina... es de las más hermosas de la tierra»: J. Klausner, Jesús de Nazaret, Buenos Aires $1971,224 \mathrm{~s}$. 109. Jn 1,46. Tal calificación del cananeo Natanael refleja bien la insignificancia histórica de Nazaret, sin "presente ni pasado alguno»: G. Dalman, Orte und Wege Jesu, Gütersloh ${ }^{4} 1924$ (= Darmstadt 1964), 61-88: 87; Cf. también B. Bagatti, Nazareth: DBS VI 31863: 318-29; C. Kopp, Die heilige Stätten der Evangelien, Regensburg ${ }^{2} 1964,86-92 . \quad 110$. Mc 7,37; 10,18par. 111. Lc 1,26; Cf. 1,19 (=Dan 9,21). Si es posible -y, en nuestra opinión, probable - que se trate de una revelación interna de Dios a María, obedeciendo la mención del «ángel» (Lc 1,26.30,34.38c) al género literario de los anuncios por «el ángel de Yahveh» sobre la vocación divina y concepción milagrosa de ilustres salvadores —Gedeón y Sansón (Jces 6-13)_ de Israel (así con S. Muñoz-Iglesias, a.c. [EstB 1957] 356s), no es imposible que Dios le haya hecho una revelación externa (así: los Padres de la Iglesia; Sto. Tomás A. [Suma Theol., III 30,3] y otros muchos autores, entre los cuales últimamente A. Feuillet, Jésus et sa Mère, Paris 1978, $161 \mathrm{~s})$, mediante uno de sus mensajeros celestes, que «Le sirven tanto en el anuncio como en la realización de su designio salvífico»: Supra, 252; Cf. C. Pozo, María 107-9. 112. Lc 1,27a.c. No hay duda, que con la doble mención de «una Virgen» y «la Virgen» subraya Lucas la virginidad (Cf. 1,34) de María (así con M.-J. Lagrange, Luc 26; A. Medebeille, a.c., 281; J.P. Audet, a.c., 356; C. Pozo, o.c., 209; C. Spinetoli, Luca 69), en probable alusión a la profecía de Is 7,14 (LXX: «La virgen» Is $7,14 \mathrm{~b}=\mathrm{Lc} 1,27 \mathrm{c}$ ), como lo reflejan los reiterados contactos literales de Lc 1,27-31 con el mencionado texto isaiano; Cf.: R. Laurentin, o.c., 72s; Les Évangiles, 61; H. Schürmann, o.c., 42.58s.; escéptico R.E. Brown, o.c., 153. 113. «De la casa de David» (Lc 1,27b) se refiere no a María - prima de Isabel y por tanto «descendiente de Aarón» (Lc 1,5.36) -, sino al descendiente «de David» José (Lc 2,4; Cf. 3,23-31), su prometido (así con: A. Medebeille, a.c., 281s; R. Laurentin, Lc I-II, 112-16; H. Schürmann, o.c., 42; R.E. Brown, o.c., 296s), quien por esto mismo encardinó a María en su genealogía davídica (Lc 3,23-31; para su análisis, Cf. M. D. Johnson, o.c., 229-52). En este sentido - sólo en éste - tienen razón los Padres de la Iglesia, que desde antiguo afirmaron la descendencia davídica de María (San Ignacio A., Ef 18,2; San Justino, Diál $45,4 ; 100,3)$, probablemente por ignorar el género literario de las genealogías bíblicas y no entender «cómo Jesús podía ser realmente de la estirpe de David a través de José»: R.E. Brown, o.c., 296s. 
Dios ${ }^{114}$ : María, personificación del «Resto fiel» y nueva «Hija de Sión» ${ }^{115}$, es invitada por el ángel a exultar por el designio divino de realizar en ella la preanunciada visita salvadora de Dios. Un designio, por lo demás, ya inaugurado. Es lo que implica la designación de María como «kecharitoméne». Pues este vocablo es, ante todo, el nombre ${ }^{116}$ nuevo y profético de «la Virgen» nazaretana: ¡El primer título mariano de la edad apostólica! Y, como todo nombre semítico, expresa lo que - según el significado etimológico de aquel vocablo- ella es: «La previa y establemente ${ }^{117}$ transformada por ${ }^{118}$ la pleni-

114. Lc 1,28b: Cf. Sof 3,14-17; J1 2,21-27; Zac 9,9-10; también: Is 12,6; 51,4; Zac 2,14. Así con: St. Lyonnet, «Chaire kecharitoméne»: Bib 20 (1939) 131-41: 132-36; Id., a.c., 39s; R. Laurentin, Luc I-II; 65-67; Les Évangiles, 67-69; L. Deiss, María, hija de Sión, Madrid 1967, 93-103; P. Benoit, o.c., 199s; A. Müller, o.c., 460; C. Pozo, o.c., 213; J. McHugh, o.c., 90-101; K. Stock, a.c., 468-71; O. Spinetoli, Luca, 70; S. Zedda, Il «chaire» di Lc 1,28 alla luce di un treplice contesto anticotestamentario: «Parola e Spirito» (Studi in on. S. Cipriani), I, Brescia 1982, 27393; J. Galot, María, 43s. Es del todo improbable que Lucas, muy familiarizado con los LXX (Cf. S. Sabugal, La conversión de san Pablo, Barcelona 1976, 72: bibliogr.), ignorase aquel transfondo veterotestamentario del saludo «chaire», el cual es por tanto más que un saludo normal [ = «shalom», «salve», «hola»], como lo refleja, por lo demás, tanto el marcado transfondo veterotestamentario de Lc 1,28d [«el Señor está contigo»]. 31-33 (Cf. infra), como el hecho de que luego María «se turbe» y no entienda el significado de «este saludo» (Lc 1,29), para ella extraño (Cf. infra.). Así contra varios autores y últimamente: R.E. Brown, o.c., 332-35; L. Legrand, o.c., 273-76. 115. Así subrayado por todos los autores citados (supra, n. 114) y también por: H.Sahlin, Der Messias und das Gottesvolk, Uppsala 1945, 99-102; Id., Jungfrau Maria Dottern Sion: Ny Kyrlig Tidskrift 8 (1949) 102-24; A.G. Herbert, The Virgin Mary as the Daughter Sion: Th 53 (1950) 403-10 (trad. fr.: VSp 85 [1951] 127-39); R. Laurentin, Luc I-II; 25-30; L. Deiss, Marie, Fille de Sion, Bruges 1959 (trad. españ., Madrid 1967); H. Cazelles, Fille de Sion et théologie mariale dans la Bible: ÉtMar 21 (1964) 51-71; M. Thurian, María, Madre del Señor, figura de la Iglesia, Zaragoza 1966, 19-29; E. G. Mori, Figlia di Sion e Serva di Jahvé, Bologna 1970; G.M. Papini, La Vergine Maria, figlia di Sion, modello della Chiesa e dell'unità del Popolo di Dio: Mar 37 (1975) 301-25; A. Feuillet, o.c., 25-30; J. McHugh, o.c., 90-107; K. Stock, a.c., 471-76. 116. Así lo asegura un ilustre filólogo neotestamentario (M. Zerwick, Analysis philogica NT, Roma $\left.{ }^{3} 1966,130\right)$ y también: A. Medebeille, a.c., 283;. J.P. Audet, a.c., 359; C. Pozo o.c., 215s; K. Stock, a.c., 467s; R. Laurentin, Les Évangiles, 30. 117. Eso indica la forma verbal en perfecto [ = la presencia del efecto causado por una acción pasada], expresando que antes del saludo del ángel fue María lo que ahora es y, sin duda, lo será después; así con: A. Medebeille, a.c., 283; J.P. Audet, a.c., 359. 118. Los verbos terminados en óô [como «charitóô»] tienen un sentido transformante o factitivo («anakainóô» = renovar, «argyróô»= argentear, "doulóô» = esclavizar, «thymóô»= irritar, «ischyróô»= fortificar, «leukóô»= blanquear, «lytróô»= rescatar, «nekóô»=matar, «stauróô»= crucificar, «stephanóô»= coronar, «kakóô»= lastimar, «tapeinóô»= humillar, «typhlóô»= cegar, etc.: Cf. J.H. Moulton-W. Howard, A Grammar of NT Greek, II, Edinburgh 1968, 393-98), latente en el otro único uso neotestamentario de aquel verbo: Dios «nos agració (echaritosen) en el Amado» (Ef 1,6), muy acertadamente explicado por antiguos comentaristas que conocían bien el griego: «Es decir, no sólo nos libró de los pecados, sino también nos hizo amables» (San Juan Cr., In Eph. I, Hom., 1: PG 62,13s; así también Teofilacto, Expos. in Ep. ad Eph. I: PG 124,1037C), o «nos gratificó con gracia espontánea, adoptándonos como hijos no por remuneración de nuestras obras» (San Juan Dam., In Ep. ad Eph.: PG 95, 824B). ¿De modo análogo fue y es María transformada por la «gracia» [= charis] de Dios! (Cf. infra); así con: R. Laurentin, Les Évangiles, 30. 
tud ${ }^{119}$ de la eficaz benevolencia o favor gratuito de Dios» ${ }^{120}$. Por ello, precisamente, es María no sólo «inmune de toda mancha de pecado» sino también «totalmente santa» ${ }^{121}:$ ¡Creaturalmente colmada de la santidad de Dios! Con Él está, pues, aquélla en plena comunión existencial. Esto exactamente le asegura el mensajero celeste, con la fórmula declarativa: « $i E l$ Señor [está] contigo!» ${ }^{122}$, frecuentemente usada en el AT como certeza de la protección y asistencia de Dios a figuras ilustres - Abraham, Jacob y José, Gedeón y Samuel, Saúl y David, Jeremías...- de la historia salvífica. ${ }^{123}$ : En María, que con Jesús es la figura culmen de aquella historia, culmina también la protección y asistencia salvadora de Dios, quien «está con» ella por haberla transformado con su favor y colmado de su santidad (Cf. supra). Se comprende,

119. Algunos verbos terminados en óô tienen también un significado de plenitud subjetiva ("Aimatóô» = ensangrentar, «kenóô» = vaciar del todo, "pleróô»=llenar totalmente, "spodóô»= cubrir de ceniza, «thaumastóô»=llenar de asombro, etc.; Cf.: G.M. Verd, a.c., 374s; A. Medebeille, a.c., 283), significado latente asimismo en el mencionado texto paulino, rectamente comentado por un autor antiguo: «Nos llenó de toda gracia» (Teodoro M., In Ep. ad Eph. I 6: ed. H.B. Swete, I 125). ¡En un grado, sin duda, mucho mayor fue y es María colmada de la «cháris» divina! (Cf. infra). 120. Eso significa «cháris»: No tanto la «gracia santificante» cuanto la actuación del eficaz favor divino, que transforma por ello al «agraciado» (Ef 1,6; Lc 1,28); así con: M. Cambe, La «charis» chez saint Luc: RB 70 (1963) 193-207: 195s; P. Benoit, a.c., 200; G.M. Verd, a.c., 359-63. 121. Conc. Vat. II, Const. LG 56. Esa transformación previa y estable de María por la plenitud del favor divino [ = «kecharitoméne»] excluye de ella ciertamente todo pecado personal y, de un modo positivo, expresa su pasada $y$ presente santidad, como lo enseñan tanto los Padres (Cf. W.J. Burghardt, o.c., 137-47.521-35; H. Graef, Maria. Geschichte der Lehre und Verehrung, Freiburg 1964, 51-96 [passim]; J.A. de Aldama, María en la patrística de los siglos I-II, Madrid 1970, 318-56; J. Ibañez-F. Mendoza, María en la Liturgia hispana, Pamplona 1975, 63-73.86-91) como los Teólogos (Cf. K. Rahner, Maria, Mutter des Herrn, Freiburg 1956, 63-84; S. Bonano, Inmunidad de pecado actual en María: «Mariología» [ed. J.B. Carol], 371-85; F.P. Calkins, La plenitud de gracia en María: Ib., 684-99; C. Vollert, María y la Iglesia: Ib., 921-66: 947-51; A. Müller, o.c., 447-52), en sintonía con la enseñanza del Magisterio de la Iglesia (Cf. E.R. Carrol, María en el Magisterio de la Iglesia: «Mariología», 5-54: 18-20; Conc. Vat. II, Const. LG 63-65; Pablo VI, Exh. apost. MC 16-20) y el unánime testimonio de su Liturgia (Cf. G. Gumbinger, María en las liturgias orientales: «Mariología», 182-223: 201ss; S. Daly, María en la liturgia occidental: Ib., 234-66: 243-47). La reflexión teológica, por tanto, puede -como lo hizo de hecho- legítimamente hacer remontar ese pasado santo de María hasta su concepción sin mancha, inmaculada: Cf. X. Le Bachelet, Immaculée conception: DThC VII 8451218: 862s; E.R. Carrol, o.c., 21-27; A. Carr-G. Williams, Inmaculada concepción de María: Ib., 307-70: 317-20; A. Müller, o.c., 439-47; C. Pozo, o.c., 296-313: 298; J. Galot, María, 185-225: 191-95. 122. Lc 1,28c: Cf. W.C. van Unnik, Dominus vobiscum. The background of a liturgical formula: «New Testament Essays» (Studies in mem. T.W. Manson), Manchester 1959, 270305: 288s; H. Schürmann, o.c., 44s. 123. Cf. W.C. van Unnik, a.c., 276-86: De las ca. 100 veces que el AT usa esa fórmula (276, n. 37), sólo.ca. 23 veces se refieren al Pueblo (284, n. 52), refiriéndose las restantes a individuos y, por cierto, no a cualquiera sino "to very special persons» (284), muchas de las cuales «estaban especialmente dotadas con el Espíritu de Dios» (285-86: 285); por lo demás, los textos en que [como en Lc 1,28c] falta la cópula, esa fórmula «es prácticamente siempre una declaración» (283) o certeza, no un deseo; aquel significado envuelve, pues, en Lc 1,28c (así con: W.C. van Unnik, o.c., 289; H. Schürmann, o.c., 45; R.E. Brown, o.c., 297) y en otros textos neotestamentarios (Jn 8,20; 16,32; Act 18,10): Cf. W.C. van Unnik, o.c., 289s. 
pues, la «turbación» de María ante «la palabra» del ángel y su «reflexión»o intento por desvelar el significado de «este saludo» (Lc 1,29). ¡Una palabra y saludo, en verdad, del todo extraños! Nuevo y extraño, en efecto, era para ella ser saludada con la invitación exultante - «ialégrate!»- dirigida no a individuos sino a la «Hija de Sión» o Israel mesiánico (Cf. supra): ¿Podía ella identificarse con el escatológico Pueblo de Dios? Del todo nuevo y extraño era también el nombre «kecharitoméne» (Cf. supra): ¿Había sido y es ella transformada por el gratuito favor de Dios? Finalmente, si el saludo con la fórmula «el Señor esté contigo» era entonces ignorado por el judaísmo ${ }^{124} \mathrm{y}$, por tanto, extraño a María, en su forma declarativa [= «está contigo»] fue reservado por el AT a muy especiales personas o figuras ilustres de la historia salvífica (Cf. supra): ¿Debía la joven nazaretana clasificarse entre éstas? El contraste manifiesto entre lo que le asegura el ángel y lo que la humilde «esclava del Señor» se considera hace, pues, del todo comprensible que María «se turbe»y, perpleja, «se interrogue». Una perplejidad y turbación, sin embargo, seguidamente superada por el mensajero celeste, quien la tranquiliza - «jno temas!»- y le asegura «haber sido favorecida por Dios» $(\mathrm{Lc} 1,30)$ más aún, sin duda, que lo fueron Noé, Abraham y Lot ${ }^{125}$, Gedeón, David y Ester ${ }^{126}$..., pues ninguno de ellos había sido «transformado por el favor de Dios» (Cf. supra) ni «alcanzaron el cumplimiento de la promesa» (Hebr 11,39) mesiánica, que a ella se le propone: «Concebir y dar a luz» o ser madre de «Jesús», el mesiánico «Hijo del Altísimo» ${ }^{127}$ y Descendiente de «David», cuyo reinado «sobre la casa de Jacob» o en el nuevo Israel «no tendrá fin» ${ }^{128}$.

Con este anuncio - jel primer kérygma neotestamentario! - finaliza la fase primera del diálogo entre el ángel y María, quien introduce la segunda fase manifestando a su interlocutor un humanamente insuperable obstáculo a la realización del designio divino sobre su maternidad mesiánica: «¿Cómo será

124. En efecto, ese saludo es raro en el AT (Jces 6,12; Rt 2,4: Cf. W.C. van Unnik, o.c., 281s) y desconocido por el Judaísmo rabínico (Cf. Str.- Bill., I 381), cuyo saludo normal (también usado por Jesús: Lc 10,5 [24,36]; Jn 20,19.21.26) era: «iLa paz sea contigo!»: Cf. Str.-Bill., I 380-85; II 584s; W. Foerster, Eiréne: ThWNT II 407;W.C. van Unnik, o.c., 272. 125. Cf. Gén 6,$8 ; 18,3 ; 19,19$. 126. Cf. Jces 6,17; Act 7,46; Est 8,5. 127. Este título expresa ciertamente la filiación adoptiva del Mesías (2Sam 7,14 [=1Crón 17,13]; Sal 2,7+89,27; Cf. 4QFlor 1,11; $1 Q S a$ 2,11-12) y, al nivel de la redacción lucana, traduce también la divina filiación natural de Jesús, designado ya «Hijo del Altísimo» (Lc 1,32a; Cf. .8,28) por «llamarse [y ser] Hijo de Dios» (Lc 1,35b) en sentido propio (Cf. infra). Así con A. Medebeille, a.c., 286. 128. Lc 1,31-33. Los contactos literales de Lc 1,31 con el oráculo isaiano sobre el Emmanuel (Is 7,14) son evidentes (Cf. M.-J. Lagrange, o.c., 30; A. Medebeille, a.c., 283; St. Lyonnet, a.c., [supra, n. 104], 41; J.P. Audet, a.c., 365; R. Laurentin, Luc I-II, 72s; H. Schürmann, o.c., 46s; C. Pozo, o.c., 217; P. Legrand., o.c., 278-80). No menos clara es la redacción de Lc 1,32-33 sobre el mesiánico transfondo veterotestamentario acerca de la filiación divina adoptiva (Cf. supra, n. 127), descendencia davídica (2Sam 7,12 [=1Crón 17,11$]$; Is 9,6+11,1) y reinado eterno (2Sam 7,16 [=1Crón 17,12.14; Sal 89,37]; Is 9,6; Dan 7,14) del Mesías, como lo subrayan justamente casi todos los autores: M.-J. Lagrange, o.c., 31; A. Medebeille, a.c., 286s; R. Laurentin, Luc I-II, 29; Les Évangiles, 60s; P. Benoit, o.c., 202; H. Schürmann, o.c., 47s; R.E. Brown, o.c., 320s; P. Legrand, o.c., 153-79. 
esto, puesto que no conozco varón?» (Lc 1,34). Esta pregunta prepara y expresa, sin duda, la libre respuesta de «la creyente» María al mencionado designio divino, pidiendo una explicación al «cómo puede ser» madre del Mesías quien es «virgen» ${ }^{129}$. No es sólo ni principalmente ése, sin embargo, el significado de ese interrogante, disparmente interpretado por teólogos y exegetas ${ }^{130}$. Un claro indicio literario, para la interpretación objetiva del mismo, nos lo ofrece Lucas en la siguiente respuesta del ángel, concluida con la confesión de que «nada es imposible para Dios» (Lc 1,37): Son las mismas palabras, con que el Señor asegura a Abraham y a Sara poder superar el obstáculo de ambos - su ancianidad y esterilidad sexual- a la concepción del hijo prometido, pues, «¿hay algo imposible para Dios?» ${ }^{131}$. No hay duda: El Evangelista, siguiendo principalmente el esquema literario del relato genesíaco sobre el anuncio del nacimiento de Isaac, formula con aquel interrogante el humanamente insuperable obstáculo - virginidad de María - a la realización del designio divino sobre la concepción y nacimiento del Mesías. Más aún: Las dificultades planteadas por aquellos dos ancianos y luego por Zacarías a la concepción de un hijo ${ }^{132}$, así como por Moisés y Gedeón a su respectiva vocación salvadora ${ }^{133}$, culminan en el obstáculo formulado por Lucas en labios de María: Prometida de José, mas aún no formalmente esposa suya, no está dispuesta, por tanto, a tener con él relaciones matrimoniales, para el inmediato futuro expresado por la promesa angélica ${ }^{134}$. Pero la superación de aquellas dificultades culminará también con la superación de este obstáculo por el mismo Dios, «a quien nada es imposible» ${ }^{135}$. Eso, exactamente, formula luego Lucas

\section{1}

129. Lc 1,27.38a.45 (infra); sobre la fe libre de María (Lc 1,34.38a-b), Cf. supra 135-37. 130. Una exposición de las diversas interpretaciones ofrecen últimamente: G. Graystone, Virgin of all virgins: The interpretation of Lk 1,34, Roma 1968, 4-36; J. McHugh, o.c., 23665; R.E. Brown, o.c., 313-17; P. Legrand, o.c., 237-40. La interpretación de aquel interrogante de María como un voto o propósito de virginidad, ignorada por los Padres de la Iglesia hasta el s. IV y, a partir de esa fecha, propuesta por algunos Padres (San Gregorio Nis., Oratio in diem natalem Christi: PG 46, 1140s; San Ambrosio, De lapsu virg., I 3; San Agustín, De sancta virg., 4; Serm. 225,2; lo silencia, sin embargo, en De civ. Dei, XVI 24,2) así como por los grandes teólogos medievales (Pedro L., Libri IV Sent., 30,2; San Alberto M., In IV Sent., 30,8-11; Sto. Tomás A., Suma Theol., III 28, 4; D. Escoto, In IV Sent., 30,2), es sostenida en los decenios pasados y actualmente por muchos exegetas y teólogos católicos: (M.-J. Lagrange, o.c., 33; B. Brodman, Mariens Jungfräuligkeit nach Lk 1,34 in der Auseinandersetzung von heute: Ant 30 (1955) 27-44; B. Laurent, Critiques et mystiques devant le voeu de virginité: RAM 31 (1955) 225-48; St. Lyonnet, a.c., 42; R. Laurentin, Luc I-II, 176-88; Les Évangiles, 35.189; M. Zerwick, «Quonian virum non cognosco»: VD 37 (1959) 212-24.276-88; P. Benoit, o.c., 205; G. Graystone, o.c., 36ss; C. Pozo, o.c., 223-25; J. McHugh, o.c., 260-65; M. Tuya, Evangelios, II (Biblia comentada, V), Madrid ${ }^{3}$ 1977, 25; A. Feuillet, o.c., 113s; J. Galot, María, 143-56: 143-46. Tal interpretación, silenciada por el Conc. Vat. II (Const. LG 56), reproduce fielmente, sin duda, la fe cristiana en la virginidad perpetua de María, pero no encuentra ningún objetivo y sólido apoyo literario en el texto lucano: Así con H. Schürmann, o.c., 51. 131. Gén 18,10-14: v. 14. 132. Cf. Gén 17,17; 18,10-12; Lc 1,18. 133. Cf. Éx $3,11+4,1.10 .13$; Jces 6,15 . 134. Así con: H. Schürmann, o.c., 50; R.E. Brown, o.c., 318; K. Stock, a.c., 482s; P. Legrand, o.c., 240s; O. Spinetoli, o.c., 74s. 135. Lc $1,37=$ Gén 18,14 ; Cf. Gén $21,1-2$; Éx 3,12+4,2-9.11-12.14-17; Jces 6,16-24; Lc $1,24-25$. 
en la respuesta explicativa del ángel al interrogante de María ${ }^{136}$ : El «Espíritu Santo descenderá sobre» ella con su poder creador y vivificante ${ }^{137}$; más aún: La misma pneumática «fuerza del Altísimo ${ }^{138}$ sombreará» a María, como «la gloria de Dios» o su visible potencia salvífica sombreaba y «llenaba» de su presencia «al Tabernáculo» mosaico ${ }^{139}$, deviniendo así ella la nueva Arca de la alianza o el lugar sagrado de la escatológica presencia salvífica del Dios santo ${ }^{140}$. En efecto, «a causa» del influjo creador y vivificante del Espíritu en María, «el [Niño] engendrado» por Aquél en ésta «se llamará [ = y será] santo» ${ }^{141} \mathrm{y}$, más exactamente, el natural o propio «Hijo de Dios» ${ }^{142}$, quien, en el nuevo santuario del maternal seno de María, personificará la presencia de la «shekiná» o potencia salvífica de Dios: Aún permaneciendo «virgen» esposa de José, aquélla será verdadera Madre del «Hijo de Dios» por el creador influjo en ella del Espíritu vivificante, como fue superada la vejez y esterilidad de su «prima Isabel» por el Dios, «a quien nada es imposible» ${ }^{143}$. Tampoco le es imposible, por tanto, fecundar maternalmente la virginidad de María. iAl contrario! Precisamente en ella se revelará culminantemente la omnipotencia vivificante y salvadora de Dios, que a lo largo de la historia salvífica se manifestó en la fecundidad de mujeres estériles ${ }^{144} \mathrm{y}$, con ello, mostró ser puro don suyo — no producto humano- la salvación del hombre: ¡No es imposible a

136. Lc 1,35. Para su interpretación, además de los autores citados, Cf.: C. Escudero Freire, Alcance cristológico y traducción de Lc 1,35, Sevilla 1975; X. Pikaza, El Espíritu Santo y María en la obra de Lucas: EphMar 28 (1978) 151-68: 155-57. Sobre la exégesis patrística, Cf.: A.R. Roover, L'exégèse patristique de Luc 1,35 des origines à Augustin, Averbode 1969; J. de Aldama, o.c., 140-66; C. Escudero Freire, o.c., 1-3. 137. Lc 1,35a. Ýa el AT subrayó el poder creador (Gén 1,2; Sal 33,6; 104, 30; Jb 33,4; Jdt 16,14; Sab 1,7;12,1) y vivificante (Is 32,15;44,3; Ez $37,1-14 ; \mathrm{Jb} 33,4)$ del Espíritu de Dios, subrayado por el Judaísmo palestinense en su targúmica paráfrasis a Gén 1,2: «Un Espíritu de amor de delante de Jahveh soplaba sobre la faz de las aguas» (TgPIGén 1,2; Cf. también E.Sjöberg, ThWNT VI 384s): ;Ese divino «Espíritu de amor», que inicialmente fecundó «las aguas» estériles, puede fecundar también el maternalmente estéril seno virginal de María! 138. Expresión sinónima de «Espíritu de Dios» (Cf. Act 1,8; 10,38): Así con H. Schürmann, o.c., 52. 139. Lc 1,35b; Cf. Éx 40,35; Núm 9,18-22. Así con: R. Laurentin, Luc I-II, 73; Les Évangiles, 70; H. Schürmanh, o.c., 53; P. Benoit, o.c., 207; C. Pozo, o.c., 226s. 140. Muy bien subrayado por R. Laurentin, Luc I-II, 74; Les Évangiles, 70-73; Cf. también C. Pozo, o.c., 227. 141. Cf. Lc 2,23; 4,34 (=Mc 1,24); Act 3,14; 4,27.30; Jn 6,69. «Santo» no es sujeto [= «lo engendrado»] sino atributo, como las más antiguas traducciones [peshitta, bohaírica, sahídica, etc.] lo entendieron ( $=$ «Por eso el que nacerá de ti es santo y será llamado Hijo de Dios»), y como se deduce del paralelismo entre Lc 1,32a.35c: Como el «Hijo del Altísimo» determina a «grande» (v. 32a), también «el Hijo de Dios» determina a «santo» (v. 35c). Así con: M.-J. Lagrange, o.c., 35s; A. Medebeille, a.c., 293; St. Lyonnet, a.c., 45; H. Schürmann, o.c., 53s; C. Pozo o.c., 227; R.E. Brown, o.c., 300; P. Legrand, o.c., 146. 142. Lc 1,35c. Así con: St. Lyonnet, a.c., 45s; R. Laurentin, Luc I-II, 141; Les Évangiles, 71; P. Benoit, o.c., 208; C. Escudero Freire, o.c., 60.72; R.E. Brown, o.c., 322. 326; A. George, Jésus Fils de Dieu: «Études sur l'oeuvre de Luc», Paris 1978, 215-36: 220. 143. Lc 1,36-37. 144. Sara (Gén 21,1-2.6), Rebeca (Gén 25,21-22) y Raquel (Gén 30,22), la madre de Sansón (Jces 13,2-5.24), Ana (1Sam 1,6.11.19-20) e Isabel (Lc 1,7.13.24s): $i$ «En la flaqueza» o esterilidad humana «se revela plenamente la fuerza" de Dios (2Cor 12.9). (que "vivifica a los muerlos y da el ser a la nadan! ( $\mathrm{Rm} \mathrm{4,17);} \mathrm{Cf.} \mathrm{a} \mathrm{este} \mathrm{respecto:} \mathrm{J.} \mathrm{Ratzinger,} \mathrm{o.c.,} \mathrm{(Einführung...),} 227$ (trad. españ., 241); R. Blázquez, o.c., 62. 
Dios hacer que «una virgen» sea también madre! ¡Es posible al Omnipotente fecundar maternalmente la virginidad de María! Así lo entendió, sin duda, «la Virgen» nazaretaná. Y, apoyándose sólo en esa omnipotencia fecundante del Espíritu de Dios, en marcado contraste con la cínicamente incrédula «risa» de Sara ${ }^{145} \mathrm{da}$ su libre asentimiento fiel al designio divino quien, autodefiniéndose «la esclava del Señor» ${ }^{146}$, expresa ya esa total sumisión a su voluntad ${ }^{147}$, seguidamente formulada con su apremiante deseo: «jHágase en mí según tu palabra!» ${ }^{148}$. Este «hágase» traduce ya, sin duda, toda la encumbrada santidad de María. Y, anticipando el obediente «hágase» getsemaníaco del creyente Jesús ${ }^{149}$, sintetiza su cristianamente insuperable y paradigmática fe: Con esa «admirable respuesta de fe» ${ }^{150}$ dio su permiso y asintió libremente al designio de Dios ella, «la creyente» cristiana $(\operatorname{Lc} 1,45)$ por excelencia y, más aún, devenida modelo de todo fiel cristiano así como «tipo de la Iglesia en el orden de la fe» ${ }^{151}$, iniciando con ello también María su cooperación positiva «a la salvación de los hombres» ${ }^{152}$.

-Con ese «fiat» de María finaliza su diálogo con el mensajero celeste. También culmina en aquél toda la acción dramática del relato lucano, cuyo desenlace indica — sólo y lacónicamente - la partida del «ángel» (Lc 1,38c), dejando envuelto en el silencio la realización del propuesto designio divino sobre la concepción del Mesías en ella por influjo del Espíritu Santo: ¡Es el silencio del misterio! Roto éste luego, sin embargo, mediante Isabel, quien saluda como «la más bendita de las mujeres» a María, por llevar ya en su «seno el Fruto bendito» del Hijo de Dios y haber devenido «la Madre del Señor» ${ }^{153}$. El inicio de esa maternidad divina coincidió, sin duda, con el «sí» fiel de la que "creyó y se cumplió en ella lo que creyó»" ${ }^{154}$. Antes de habitar el Hijo de Dios en el seno de María, sin embargo, había ya sin duda «morado Cristo por la fe

145. Cf. Gén 18,12-15. 146. Lc 1,38a. María se considera, por tanto, inferior a una «sierva»: M.-J. Lagrange, o.c., 39s. 147. La expresión «he aquí a tu esclava» traduce la total sumisión a la voluntad de otro (1Sam 25,41; 2Sam 9,6; 2Re 4,16; etc.); Cf. K.H. Rengstorf, Doúlos: ThWNT II 268-70. 148. Lc 1,38b. La resonancia de Gén 21,1 y 30,34 (LXX) es clara; así con: H. Schürmann, o.c., 58; I.H. Marshall, The Gospel of Luke, Exeter 1978,72. 149. Lc 22,42par: Cf. supra, 136 (n. 157). 139 (n. 197). 150. R. Laurentin, Les Évangiles, 36.194. Muy bien subrayada también la fe libre expresada en ese «fiat» de María, por: A. Medebeille, a.c., 296; J. Schmid, Lukas, 44 (trad. españ., 64); P. Benoit, o.c., 208s; H. Schürmann, o.c., 58; A. Müller, o.c., 464-66; A. Feuillet, o.c., 120s; Cf. supra, 136. 151. Conc. Vat. II, Const. LG 63. Sobre la fe de María, Cf. supra, 135-37. 152. Conc. Vat. II, Const. LG 56. Así también: M.J. Nicolás, Marie, Mère du Sauveur, Paris 1967,101s; A. Müller, o.c., 466-69; C. Pozo, o.c., 229; A. Feuillet, o.c., 120. Sobre la cooperación de María a la obra de la salvación, Cf.: C. Dillenschneider, Le mystère de la corredemption mariale, Paris 1951; E. Schillebeeckx, Marie, Mère de la Rédemption, Paris 1963; C. Vollert, Principio fundamental de la Mariología: «Mariología» (ed. J.B. Carol), 431-87: 470ss.; Id., María y la Iglesia: Ib., 921-66: 951-54; J.B. Carol, Corredención de nuestra Señora: Ib., 760-804; M.-J. Nicolás, o.c., 100-110; R. Laurentin, Court traité sur la Vierge Marie, Paris 1968, 141-45; Id., Maria nella storia della salvezza, Milano 1972, 122-37; C. Pozo, o.c., $42-50$ (bibliogr.); A. Feuillet, o.c., 214-22; J. Galot, Maria, 239-92. 153. Lc 1,42-43. 154. San Agustín, Serm. 215,4. «En el alma la fe, y en el vientre Cristo»: Id., Serm. 196,1 . 
en el corazón» (Ef 3,17$)$ de quien, por la fe, le «concibió antes en su mente que en su vientre» ${ }^{155}$ virginal, cuya morada corporal inició Aquél con el consciente y libre «fiat» de «la esclava del Señor». ;Entonces el eterno y divino «Verbo se hizo carne» en ella e inició la redención de la carne! ¡Entonces el Hijo de Dios entró en este mundo», tras «haberle preparado un cuerpo» en el seno de María el mismo «Espíritu de Dios», que al principio «se cernía sobre las aguas» y de la nada creó el ser ${ }^{156}$, dando inicio a la «nueva creación» con la generación del «Hombre nuevo!» ${ }^{157}$. ¡Entonces «llegó la plenitud de los tiempos» y «envió Dios a su Hijo, devenido [hombre] de mujer» y «del linaje de David según la carne»! ${ }^{158}$. ¡Entonces «se manifestó la bondad de Dios nuestro salvador y su amor a los hombres» pecadores, entregando «a su Hijo único al mundo para que viviésemos por Él» o fuese «propiciación por nuestros pecados»y, creyendo «en Él», tuviésemos «vida eterna»! ${ }^{159}$. ¡Entonces inició la «kénosis» de Quien era «igual a Dios» y se hizo «Siervo» en todo «semejante a los hombres» ${ }^{160}$, para liberar a los hombres! ¡Entonces se inauguró la secularización del Hijo de Dios o su venida «al mundo [= saeculum], para salvar a los pecadores» o «al mundo» pecador! ${ }^{161}$. ¡Entonces «la Virgen María desató con su fe lo atado con su incredulidad por la virgen Eva»! ${ }^{162}$. ¿Entonces también «la Virgen» de Nazaret devino «la Madre del Señor»! ${ }^{163}$. Pues eso fue y es María:

\section{3) Virgen y Madre}

Es lo que atestiguan, como hemos visto, los dos analizados textos de los evangelistas Mateo y Lucas, subrayando independientemente ambos el hecho de la virginidad maternal y de la maternidad virginal de María, devenida por designio divino «la Madre Virgen» (San Cirilo A.) o «la Virgen Madre» (San León M.), es decir, «Madre de Cristo y Virgen de Cristo» ${ }^{164}$. Ella, en efecto, es:

a) «La siempre Virgen» ${ }^{165}$

Así es designada por el Magisterio de la Iglesia ${ }^{166}$, en fidelidad a los res-

155. San Agustín, Serm. 215,4; Cf. Serm. Denis 25,7. Por lo demás, «María fue más feliz por recibir la fe de Cristo que por concebir la carne de Cristo», ya que «nada habría aprovechado la divina maternidad a María, si no hubiese sido más feliz por llevar a Cristo en su corazón que en su carne»: Id., De santa virg., 4. 156. Hebr 10,5; Gén 1,2: Cf. supra, n. 137 157. Cf. J. Ratzinger, o.c., 223.229 (trad. españ., 239.243); Ph. Schäfer, o.c., 47 (trad. españ., 65). 158. Gál 4,4; $\mathrm{Rm} 1,3$. 159. Tit 3,$4 ; 1 \mathrm{Jn} \quad 4,9-10 ; \quad J n \quad 3,16$. 160. Fil 2,6-7. 161. 1 Tim 3,$15 ;$ Jn 3,$17 ; 12,47$ 162. San Ireneo, Adv. Haer., III $22,4=$ Conc. Vat. II, Const. LG 56. Sobre la tipología y contraposición Eva-María en la mariología patrística, Cf.: AA.VV., La nueva Eva (EstMar 18), Madrid 1957; W.J. Burghardt, o.c. [«Mariología»], 11219; J.A. de Aldama, o.c., 264-99 (bibliogr.). 163. Lc 1,27.43. 164. San Agustín, De sancta virg., 6. 165. Cf. a este respecto: Sto. Tomás A., Suma Theol., III 28,1-4; A.M. Sancho, La virginidad de María, Madre de Dios. Estudio histórico y teológico del dogma, Madrid 1955 (bibliogr.); K. Rahner, María, 62-72; J.A. de Aldama, Virgo Mater, Granada 1963; Id., o.c., 81- 
pectivos testimonios patrísticos ${ }^{167}$ y litúrgicos ${ }^{168}$ sobre la virginidad perpetua de María, protectora y modelo de cuantos «por la virginidad o el celibato se consagran de nuevo y excelente modo a Cristo», para, «en Él y por Él», entregarse «más libremente al servicio de Dios y de los hombres» ${ }^{169}$. Ese unánime testimonio sobre «la siempre Virgen», eco de la fe cristiana profesada en el Símbolo, confiesa la virginidad antes del parto de la Madre de Cristo, a quien «concibió sin semen» viril y «por obra del Espíritu Santo» ${ }^{170}$. Sólo Éste y una Virgen podían engendrar al inagotable y puro Amor, que se da sin recibir, se somete sin dominar, libera sin oprimir y salva sin condenar; al Amor que «no resiste al malvado» y «ama al enemigo», venciendo así «al mal con el bien» y mostrando ser «más fuerte que la muerte». ¡Ese amor no lo puede producir quien -el hombre y la mujer- no lo tienen! iSólo el Espíritu y una Virgen podían engendrar al Amor espiritual y virginal! Esto confiesa también la Iglesia, cuando cree que el encarnado Hijo de Dios fue concebido de la Virgen María por el Espíritu Santo. Una confesión de fe, por lo demás, sólidamente enraizada en el reiterado testimonio evangélico, según el cual «antes de» cohabitar con José, «se encontró encinta por obra del Espíritu Santo» María, «la Virgen» que, «sin conocer varón» o tener relaciones matrimoniales con aquél, por fecundante influjo del «Espíritu Santo» en ella devino «la Madre del Señor» o del Logos encarnado, «engendrado» en su seno «no por un deseo car-

247; M.-J. Nicolás, o.c., 77-80.88; E.R. Carrol, o.c. [«Mariología»], 13-18; W.J. Burghardt, Ib., 119-32.499-514; G. Gumbinger, Ib., 201-33 (passim); S. Daly, Ib., 248s; Ph. J. Donnely, Ib., 619-83; A. Müller, o.c., 479-86; R. Laurentin, María, 98-121; Les Évangiles, 470-501; C. Pozo, o.c., 250-84 (bibliogr.); J. Ibáñeż-F. Mendoza, o.c., 42-53.75-81; J. McHugh, o.c., 218-426; R.E. Brown, o.c., 541-57; F. de Paola Sola, La virginidad perpetua de María y sus modernas interpretaciones: EstMar 42 (1978) 93-111; J. Galot, o.c., 113-83. Más bibliografía: Supra, nn. 78.94.104; infra, nn. 170.175.182. 166. Ya el primer Conc. Later. (a. 649: Denz. 256), implícitamente Pablo IV (a. 1555: Denz. 993) y, de modo explícito, últimamente Pablo VI (Solemne Profesión de fe, 14); Cf.: E.R. Carrol, «Mariología», 5-53: 13-18; C. Pozo, o.c., 260; Id., El Credo..., 132s; J. Ibáñez-F. Mendoza, o.c., 78-81; J. Galot, o.c., 158-60. 167. La virginidad perpetua de María es atestiguada por los comentarios a este artículo del Símbolo de San Atanasio, San Cirilo A., San Basilio, San Juan Cr., San Ambrosio, San Agustín (Cf. también: Serm. 186,1; 189,2; 191,1.2), San Pedro Cr. y San León M. (Cf. supra), designándola varios Padres la «Aiparthénos» o la «semper Virgo» (Cf. J.A. de Aldama, o.c., 287-97); a este respecto, Cf.: Id., o.c., 213-47; María, 225-47; W.J. Burghardt, «Mariología», 119-32 [=Padres occid.]. 499-514 [= Padres orient.]; Ph.J. Donnely, Ib., 635-83; F. Spedalieri, María, II.1, Roma 1968, 289-329; C. Pozo, o.c., 254-59; I. Ibáñez-F. Mendoza, o.c., 42-53.75-78. 168. Cf. G. Gumbinger, «Mariología», 182-233: 201ss [=Liturg. orient.]; S. Daly, Ib., 234-66: 248s [= Liturg. occident.]. 169. Conc. Vat. II, Decr. PO 16.18; así lo subrayaron ya los Padres de la Iglesia (Cf. F.D.B. Vizmanos, Las vírgenes cristianas de la Iglesia primitiva, Madrid 1959, 37883) y luego Pío XII, Enc. Sacra virginitas: AAS 46 (1954) 161-91: 187s. Sobre el significado y actualidad de la virginidad cristiana y el celibato sacerdotal, Cf.: W. Molinski, Virginidad: SM VI 865-73 (bibliogr.); A. Auer, Virginidad: CFT II 883-89 (Bibliogr.). 170. Conc. Later.: Denz. 256; así también Pablo IV (Denz. 993) y Pablo VI (loc. cit.: supra, n. 166); Cf. a este respecto: C. Pozo, El Credo, 97-100; J. Galot, o.c., 116-19. Sobre el respectivo testimonio de los Padres y de la Liturgia de la Iglesia, además de la bibliografía citada, Cf.: J.A. de Aldama, Virgo Mater, 22246; Id., María, 81-188; C. Pozo, María, 254s; J. Galot, o.c., 115s. 
nal ni por deseo viril ${ }^{171}$ sino por Dios» ${ }^{172}$. El mismo Dios que, superando con el don de un hijo tanto la vejez de Abraham y de Sara, de Zacarías e Isabel, como la esterilidad de Sara, Rebeca y Raquel, de las madres de Sansón, Samuel y Juan Bautista, mostró ser Él quien tomó la iniciativa y guió la historia de la salvación, cuando alcanzó ésta su culmen o «llegó la plenitud de los tiempos» y decidió «Dios enviar a su Hijo» al mundo ${ }^{173}$, manifestó culminantemente su omnipotencia salvífica - «inada es imposible para Dios!»- superando el humanamente insuperable obstáculo de la virginidad de María (Cf. supra). Ésta es, pues, un momento - por cierto, culminante- de aquella normal pedagogía divina, revelada a lo largo de la historia salvífica por el Dios que, en los obstáculos y en la debilidad humana, manifiesta la fuerza de su gracia ${ }^{174}$. Revelada ésta también, de algún modo, en el parto virginal de María ${ }^{175}$, cuyo Hijo «fue engendrado por Dios» en ella «no de las sangres»: sin el abundante [= «sangres»] derrame de sangre, que acompaña normalmente a todo parto ${ }^{176}$. Aquél, por el contrario, «nació de María virgen» ${ }^{177}$. Un nacimiento virginal, por lo demás, propio de Quien «con su cuerpo no violó la virginidad de la Madre», pues «si al nacer Él se hubiese violado su inte-

171. Es decir, de José: Los evangelistas nunca hacen suya la opinión popular, según la cual «se creía» entonces que Jesús era «hijo [natural] de José» (Lc 3,23; Cf. 4,22 [= Mt 13,55]; Jn $1,45 ; 6,42)$, contraponiendo o subrayando aquéllos luego, por el contrario, su filiación divina (Cf. Lc 2,48-49; 3,23.38; Jn 1,45.49; 6,42-46). A este respecto, Cf. I. de la Potterie, a.c. [Mar 1978], 45-59=o.c., [María-Virgen], 15-33. Menor valor exegético tienen los análisis de B. Llamera, Teología de San José, Madrid 1953, 78ss. 172. Mt 1,18.20.23; Lc 1,27.34-35.43; Jn 1,13 (Cf. supra; a este respecto, Cf. también la información bibliográfica sobre el tema en los últimos 30 años ofrecida por J.M. Alonso, La concepción virginal: EphMar 26 [1976] 247-306). Ese triple e independiente relato evangélico sobre la concepción virginal de Jesús afirma algo ignorado por la restante literatura neotestamentaria (no se contiene en Gál 4,4: Si tal fue y es su interpretación por muchos Padres y exegetas [Cf. E. de Roover, La maternité virginale de Marie dans l'interprétation de Gal 4,4: «Studiorum Paulinorum Congressus», Rome 1963, 17-37; últimamente J. Winandy, a.c., supra, n. 78,716-19], el texto paulino nada dice al respecto; así con: M.-J. Lagrange, Épitre aux Galates, Paris 1950, 102; H. Schlier, Der Brief an die Galater, Göttingen 4 1965, 196; F. Mussner, Der Galaterbrief, Freiburg 1974, 270): aquellos relatos evangélicos o no son, pues, creación de la Comunidad post-pascual; fueron redactados asimismo por los Evangelistas en franca desintonía con el testimonio judaico sobre la concepción natural — «hombre de hombres!»- del Mesías (Cf. S. Sabugal, Christós, Barcelona 1972, 51). El triple testimonio evangélico sobre la virginidad perpetua de María, por tanto, sólo tiene una explicạción científicamente válida: Está en la tradición evangélica, porque estuvo en la historia (Así con: J. McHugh, o.c., 399-407; R. Laurentin, Les Évangiles, 470-93). Es, pues, del todo erróneo afirmar, que «los datos bíblicos controlables científicamente dejan sin resolver la cuestión de la historicidad de la concepción virginal»: R.E. Brown, o.c., 551. 173. Gál 4,4; Cf. Hebr 1,2; Mc 1,15. 174. Cf. 2Cor 12,7-10; 4,7-12. 175. A este respecto, además de la bibliografía citada (supra, nn. 78.165), Cf.: R. Laurentin, Le mystère de la naissance virginale. À propos d'un livre récent: EphMar 10 (1969) 345-47; Id., Maria, 51s; J.A. de Aldama, Virgo Mater, 19-285; María, 189-224; K. Rahner, «Virginitas in partu». En torno al problema de la tradición y de la evolución del dogma: ET IV, Madrid 1964, 177-211 (bibiogr.: 177); C. Pozo, o.c., 256-64; I. de la Potterie, a.c. [Mar 1978], 6877; Id., a.c. [Mar 1983], 139ss; J. Galot, Maria, 157-75. 176. Jn 1,13a: Cf. supra, 416. Cristo fue, pues, dado a luz por María «sin dolor» (Od. Salom., 19,8); así también San Ireneo (Exposición, 54), y otros Padres del s. II se expresan de modo análogo: Cf. J.A. de Aldama, María, 189ss. 177. Así lo atestiguan los antiguos Símbolos de la Fe: Cf. supra, 335s. 
gridad, no habría nacido de una Virgen y, entonces, sería falso... que hubiese nacido de María virgen, como confiesa toda la Iglesia» ${ }^{178}$. Así lo enseña también su Magisterio: María «engendró incorruptiblemente» a Cristo ${ }^{179}$, «su Hijo primogénito, quien, lejos de menoscabar, consagró la integridad virginal» de la Madre ${ }^{180}$. Y es que la maternidad divina de María es la más acabada participación de la virginal paternidad de Dios, por haber aquélla concebido en el tiempo sin padre a quien en la eternidad fue engendrado por Dios sin madre ${ }^{181}$. También por ello es María «la siempre Virgen» incluso tras haber dado a luz a su Hijo, como lo confiesa la fe de la Iglesia, cuyo Magisterio -en fidelidad a la tradición patrística y litúrgica- enseña que aquélla «permaneció aún después del parto» virgen ${ }^{182}$. Una enseñanza, por lo demás, profundamente enraizada en el subsuelo de los cuatro Evangelios. Sus autores, en efecto, ignoran la expresión «hijos de María» o «hijos de José». Y, según el evangelista Marcos, Jesús es designado despectivamente por los nazaretanos

178. San Agustín, Serm. 214,6; Enchir. 34. La «virginidad en el parto», efectivamente, es ya en el s. IV fe común de toda la Iglesia, como se refleja en los múltiples y geográficamente vastos testimonios patrísticos y litúrgicos: Cf. J.A. de Aldama, Virgo Mater, 19-49; K. Rahner, o.c. [ET IV], 198-200; C. Pozo, o.c., 257-59; I. de la Potterie, a.c. [Mar 1983], 151-58; J. Galot, o.c., 166-70. Esa fe de la Iglesia refleja la designación de María por los Padres como «Aiparthénos»o «semper Virgo» (supra, n. 167; G.W. Lampe, Lexicon, 38: ad voc.) y «Pánagnos»=totalmente aasta (Cf. G.W. Lampe, o.c., 1001). La tradición teológica postpatrística está muy bien representada por «el Doctor angélico», según el cual «sin duda alguna» se debe afirmar, que la madre de Cristo fue también virgen en el parto, pues el profeta [ = Isaías] no sólo dice «he aquí que la Virgen concebirá», sino añade «y dará a luz a un hijo»: Sto. Tomás A., Suma Teol., III 28,2. 179. Conc. Later. (a. 649: Denz. 256. Este aserto, sin embargo, no es una definición dogmática: Cf. K. Rahner, o.c., 183s; J. Galot, o.c., 158s; contra: J.A. de Aldama, Virgo Mater, 101-27; C. Pozo, o.c., 259). Análoga enseñanza formuló Pablo IV, rechazando con su «autoridad apostólica» la opinión de quienes «se desvían y desertan de la fe católica» negando, entre otras cosas, que María «permaneció siempre en la integridad de la virginidad, a saber, antes del parto, en el parto y perpetuamente después del parto» (Denz. 993). Se trata, pues, de una «verdad de fe» cristiana (Cf. K. Rahner, o.c., 180-85), no definida sin embargo por el Magisterio. 180. Conc. Vat. II, Const. LG 57 (en referencia explícita al Conc. Later. [Cf. supra, n. 179] y con una terminología netamente agustiniana: Cf. supra, n. 178). El significado de este aserto conciliar se encuadra en el contexto de la opinión sostenida por varios teólogos católicos, según los cuales la «virginidad en el parto" no contradice y sí se armoniza con un parto normal y, por tanto, doloroso de María, requerido éste por la plena maternidad de aquélla y su misión corredentora: Cf. A. Mitterer, Dogma und Biologie der Heiligen Familie, Wien 1952, 98-129: 111ss; a él se adhirieron otros autores (citados por K. Rahner, o.c., 179), entre los cuales últimamente J. Galot, o.c., 170-75. Aquel aserto conciliar no quiso «condenar la tesis del parto normal» y sí dejó «a los teólogos la libertad de discutir sobre el modo de nacer [Cristo], con tal que se reconozca la integridad virginal de María»: J. Galot, o.c., 161 (lo cursivado es nuestro). 181. Cf. San Agustín, In Ioan. Ev. tract. 8,8; Serm. 186,1; 189,4;214,6;215,4. 182. Conc. Later. (a. 649): Denz. 256; así también Pablo IV (Denz. 993) y últimamente Pablo VI, Solemne Profesión de fe, 14 («Creemos que la bienaventurada María permaneció siempre virgen»). A este respecto, además de la bibliografía citada (supra, n. 78), Cf.: M.-J. Lagrange, Évangile selon saint Marc, Paris (1929) 1966, 79-93; J.A. de Aldama, Virgo Mater, 213-47 [testimonios patrísticos y litúrgicos]; Id., María, 225-47 [testimonios patrísticos desde el s. II]; C. Pozo, o.c., 255-56.264s; Id., El Credo, 132s; J. Galot, o.c., 176-83. 
«el carpintero, el hijo de María» ${ }^{183}$ : No por haber muerto ya José, pues en la opinión popular aquél seguía siendo designado «el hijo de José» (Cf. supra) y, por lo demás, la designación según el nombre de la madre - aún tras la muerte del padre- era entonces del todo inusitada; tras la designación «el hijo de María late, pues, la concepción de Marcos sobre la exclusiva filiación mariana de Jesús. Pues eso es María: «La madre de Jesús» ${ }^{184}$ o «su madre» ${ }^{185}$, de quien nunca se dice que tuviese otros hijos ${ }^{186}$ y sí se afirma que «dio a luz al hijo suyo, el primogénito» y único Hijo ${ }^{187}$. ¿Habría éste entregado a su madre a un discípulo ${ }^{188}$, si hubiese tenido hermanos carnales? Ese gesto del agonizante Jesús sólo es inteligible, si Él era el unico hijo de María; «su madre» (Cf. supra). Éste es, pues, un dato sólidamente atestiguado por toda la tradición evangélica ${ }^{189}$. En modo alguno contradicho por la mención de «los hermanos ${ }^{190}$ y las hermanas» ${ }^{191}$ de Jesús, frecuentemente aducida por los exegetas protestantes contra la virginidad perpetua de María ${ }^{192}$. ¡Del todo injustamente! Pues además de contradecir el mencionado dato evangélico y desintonizar con el prácticamente unánime testimonio multisecular de la Iglesia ${ }^{193}$, está desprovista de un sólido fundamento literario. En efecto, un análisis científico de los textos bíblicos sobre el uso del vocablo «hermano» ${ }^{194}$

183. Mc 6,3. Por ser ésa la «lectio» menos cristiana - ¡despectiva!-y más difícil, ha de ser preferida a las otras dos variantes: La [mateana] «el hijo del carpintero» ( $\mathrm{p}^{45}$ etc. Cf. Mt 13,55) y la armonizante «el hijo del carpintero y de María» (it arm Or 33 etc.) 184. Jn 2,1; Act 1,14; Cf. Lc 1,43. 185. Mt 1,18; 2,1.13.14.20.21; 12,46par; 13,55; Lc 2,33.48.51; In 2.3.5.12; 19,25.26; Cf. 6,42; Lc 2,34. 186. Sobre Mt 1,25. Cf. supra, 419, n. 102. 187. Lc 2,7. En griego bíblico, en efecto, «el primer hijo se llama primogénilo, independientemente si le siguen o no otros hijos» (W. Michaelis, Protótokos: ThWNT VI 872-86: 877), dato lexicográfico corroborado por la inscripción sepulcral judía (a. 5 a.C.), sobre la muerte de una joven madre durante el parto de su primer hijo y por ella designado «mi primogénito» (Cf. W. Michaelis, a.c., 873; J.B. Frey, La signification du terme «protótokos» d'après une inscription juive: RB 11 [1930] 373-90). Por lo demás, «el hijo» de María es designado por Lucas «su primogénito» $(\mathrm{Lc} 2,7)$ y no «unigénito» $(\mathrm{Lc} 7,12 ; 8,42 ; 9,38)$ por anticipar el relato sobre la purificación de aquélla y presentación de Jesús al Señor (Lc 2,22-24), conforme a la prescripción mosaica sobre la consagración «de todo varón primogénito al Señor» (v. 23); así con M.-J. Lagrange, Luc 71; J. Schmid, Lukas, 65 (trad. españ., 94s); H. Schürmann, o.c., 104. 188. Jn 19,26-27. 189. Del todo erróneo es afirmar, que «la cuestión de la virginidad perpetua de María pertenece a la teología postbíblica» (R.E. Brown, o.c., 131: lo cursivado es nuestro): ;Se enrai$z a$ en la teología de los cuatro Evangelistas! 190. Mc 3,31-32par; 6,3a [ = Mt 13,55]; Jn 2,12; 7,3.5.10; Act 1,14; Gál 1,19; 1Cor 9,5. 191. Mc 3,32; 6,3b=Mt 13,56a. 192. Cf. J.B. Lightfoot, St. Paul's Epistle to the Galatians, London ${ }^{10} 1983,252-91$ [ = «The Brethern of the Lord»]; Th. Zahn, Brüder und Vettern Jesus (FGKL VI), Leipzig. Erlangen 1900, 224-364; E. Meyer, Urgeschichte des Christentums, I, Stuttgart 1921, 70-77; últimamente L. Oberliner, Historische Überlieferung und christologische Aussage. Zur Frage der «Brüder Jesu» in der Synopse, Stuttgart 1975. Así también -ilamentablemente! - algunos exegetas católicos: R. Pesch, Das Markusevangelium, I, Freiburg 1976, 322-24; J.A. Fitzmyer, Catecismo cristológico, Salamanca 1984, 78-80: 80. 193. Cf. supra, n. 182; M.-J. Lagrange, Marc, 86-92; J. Blinzler, o.c. [infra, n. 194], '130-44; J. Galot, o.c., 181s. 194. Particularmente brillantes son los análisis de M.-J. Lagrange (Marc, 79-83) y J. Blinzler, Die Brüder und Schwestern Jesu (SBS 21), Stuttgart 1967; Cf. también: Id., Brüder Jesu: LThK II 714-17; Die Brüder Jesu: «Aus der Welt und Umwelt des 
muestra que, por no poseer el hebreo ni el arameo un vocablo para designar al «primo» o a la «prima», lo hace frecuentemente con los vocablos «hermano» (LXX: «adelphós») y «hermana» (LXX: «adelphé») respectivamente ${ }^{195}$, dato lexicográfico atestiguado asimismo por la literatura griega extrabíblica de entonces ${ }^{196}$. Es, pues, cierto que, si Jesús tenía primos y primas, en arameo sólo podían ser designados «sus hermanos y hermanas», siendo por tanto posible que los así designados sean en realidad «sus parientes» (Mc 3,21) o primos y primas. Éstos son, en efecto, sus «hermanos Santiago y José», ambos hijos de otra «María» ${ }^{197}$, probablemente identificada con «la hermana de su Madre, María la [mujer] de Cleopás» ${ }^{198}$. En todo caso, ese texto joanneo es testimonio seguro de que la Madre de Jesús tenía una hermana: Si ésta estaba casada, Jesús tenía ciertamente primos, teniendo que ser necesariamente designados en arameo «hermanos» de Quien fue «el hijo de María». El testimonio evangélico es, pues, suficientemente claro para que se asiente a la virginidad perpetua de María, y suficientemente oscuro para rehusar tal asentimiento fiel: ;Es el claroscuro de la fe profesada por la Iglesia en «la siempre Virgen»! La cual, por haber concebido al Hijo «engendrado por Dios», es:

b) «La Madre de Dios» 199

Así es confesada María por el antiguo y hodierno Magisterio de la Iglesia ${ }^{200}$, expresando esta confesión de fe cristiana, con fidelidad, el respecti-

NT", Stuttgart 1969, 54-61; A. Durand, Les frères du Seigneur: RB 5(1908) 1-35; F. Prat, La parenté du Jésus: RSR 17 (1927) 127-38; J.B. Bauer, Hermanos de Jesús: DTB 447-49 (bibliogr.); J. 'Sánchez, La Madre y los hermanos de Jesús: EstMar 32 (1969) 91-108; A. Müller, o.c., 479-82; C. Pozo, o.c., 264s; J. McHugh, o.c., 266-327 (bibliogr.); J. Galot, o.c., 176-86: 179-82. 195. Así, por ejemplo: Gén 13,$8 ; 14,14.16 ; 24,48 ; 29,12.15 ; 31,23.32 ;$ Lev 10,4; Jos 17,4; Jces 9,3; $2 \operatorname{Re} 10,13$; 1Crón 23,21-22 (en todos esos textos usan también el vocablo «hermano» o «hermana» tanto los LXX como el Targum): Cf. M.-J. Lagrange, o.c., 80s; J. Blinzler, o.c., 41-44. 196. Así el historiador hebreo Fl. Josefo (Ant. Jud., I 209,211; Bell. Jud., VI 35657) y textos papirológicos del s. II-I a.C.: Cf. J. Blinzler, o.c., 44s. 197. Mc 6,3a+15,40; designada luego «María la [madre] de José» (Mc 15,47) y «María la [madre] de Santiago» (Mc $16,1=$ Lc 24,10), es decir, «la otra María» (Mt 27,61; 28,1): Cf. J. Blinzler, o.c., 73-86; M.-J. Lagrange, o.c., 83. 198. Jn 19,25. Así M.-J. Lagrange, o.c., 84.93; Jean, 493; R.E. Brown, St. John, II 905s: trad. españ., 1199 («es posible»), y otros autores - protestantes y católicos- citados por J. Blinzler, o.c., 113, n. 11; el texto joanneo, sin embargo, no arroja certeza sólida: Cf. Id., o.c., 111-18. 199. Cf.: H. Vorgrimler, Theotokos: LThK X 96 (bibliogr.); K. Rahner, María, 51-61; G. van Ackeren, La divina maternidad de María: «Mariología» (ed. J.B. Carol), 570-618; M. Thurian, o.c., 97-123; M.-J. Nicolás, o.c., 80-88; R. Laurentin, Court traité, 118-38; María, 86-97; A. Müller, o.c., 458-70; C. Pozo, o.c., 285-95 (bibliogr.); J. McHugh, o.c., 90-122; J. Ibáñez-F. Mendoza, Origen e historia del dogma de la maternidad divina de María: EstMar 42 (1978) 57-71; E. Sauras, La maternidad divina de María en las nuevas cristologías: Ib., 73-92; J.M. Alonso, Maternidad divina y cristologías recientes: EphMar 30 (1980) 7-68; J. Galot, o.c., 91-112. 200. Explicitando la fe profesada por los antiguos Símbolos «en el Hijo de Dios..., concebido por el Espíritu Santo de María la Virgen» (Cf. supra, 335), ésta fue designada «Madre de Dios» [= Theótokos] ya en los s. III-IV (Cf. J. Galot, o.c., 93), designación usada solemnemente por el Conc. de Éfeso (Denz. 111a.112: Cf. A. Grillmeier, Jesus der Christus im Glàube der Kirche, I, Freiburg 1979, 637-726; S.M. Meo, La «Thotokos» al concilio ecuménico di Efeso 
vo testimonio patrístico ${ }^{201}$ y litúrgico ${ }^{202}$. Confesión y testimonio, por lo demás, arraigados en el sólido dato neotestamentario. Pues la «Mujer», de quien «devino» hombre «el Hijo enviado por Dios» al mundo, es María: «La Madre del Señor» ${ }^{203}$ o «la Madre de Jesús» ${ }^{204}$, en ella «engendrado por Dios» o concebido «por el Espíritu Santo» y siendo, por ello, «Hijo de Dios» ${ }^{205}$ aquel, quien luego invocó siempre a Dios con la filial familiaridad e intimidad de un hijo natural a su verdadero padre $[=«$ AAbbá!»], por saberse o tener clara conciencia de ser Hijo natural suyo ${ }^{206}$; nada de extraño, pues, si luego Jesús enseñó, exigió y obró con autoridad y poder exclusivos del mismo Dios ${ }^{207}$, siendo asimismo confesado por la Iglesia como «mi Señor y mi Dios»o «el Dios verdadero» ${ }^{208}$. Su Madre es, pues, verdadera «Madre de Dios». iInsuperable don, otorgado por el Creador a su creatura! ¡Inigualable dignidad, concedida por Dios a un ser humano y, por cierto, a una mujer!: De ningún hombre afirma la revelación neotestamentaria y confiesa la Iglesia ser padre de Dios, reservando por el contrario y exclusivamente a «una mujer» $($ Gál 4,4$)$ - María - el honor - ¿antifeminismo bíblico y cristiano? - de ser la «Théotokos», verdadera Madre de Dios. ¡Incomparable dignidad humana de María! La joven «Virgen» de Nazaret devino «la más bendita de las mujeres» por ser «el Fruto de su seno bendito» y «santo, Hijo de Dios» ${ }^{209}$. ¡Precisamente «por eso» la felicitaron, felicitan y «felicitarán todas las generaciones»! ${ }^{210}$ : Por ser la Madre del Logos encarnado, de Cristo y, en calidad de tal, también Madre de todos los cristianos:

c) «La Madre de la Iglesia»

Con este título fue proclamada recientemente María por el supremo Magisterio de la Iglesia ${ }^{211}$. Y con razón. Pues ese nuevo título mariano sintetiza y expresa, en rigor, las implicaciones teológicas de la fe cristiana en la maternidad divina de María, quien con su creyente «fiat» devino Madre de Cristo

(a. 431), Roma 1979) y por el Conc. de Calcedonia (Denz. 148), siendo luego así designada María por Pablo IV (Denz. 993) y, más recientemente, tanto por el Conc. Vat. II (Const. LG 52.53) como por Pablo VI (Solemne Profesión de fe, 14). A este respecto, Cf.: E.R. Carrol, o.c., 9-13; C. Pozo, o.c., 291-93; Id., El Credo, 131; J. Galot, o.c., 95-99. 201. Cf.: J.A. de Aldama, Virgo Mater (passim!); W.J. Burghardt, o.c., 132-37.514-21; C. Pozo, María, 287-90; J. Ibáñez-F. Mendoza, o.c., 28-42.74s; J. Galot, o.c., 91-95. 202. Cf. G. Gumbinger, o.c., 201-6 (у passim); S. Daly, o.c., 237-42. 203. Gál 4,4; Lc 1,43. 204. Mt 1,18; 2,11.13.14.20.21; 12,46par; 13,55; Lc 2,33.34.48.51; Jn 2,1.3.5.12; 19,25.26; Act 1,14. 205. Jn 1,13; Mt 1,18.20; Lc 1,35. 206. Mc 14,36; Mt 11,25 [= Lc 10,20]; Jn 5,18 etc: Cf. S. Sabugal, $A b b a \ldots$ La.Oración del Señor, Madrid 1985, 382-97. 207. Cf. supra, 319s. 208. Jn 20,28; 1 Jn 5,20; Cf. Jn 1,1.18; $R m$ 9,5; Fil 2,6. 209. Lc 1,27.42.35. 210. Lc 1,48. 211. Lo hizo [21.XI.1964] Pablo VI, clausurando los trabajos de la 3. ${ }^{a}$ etapa del Conc. Vat. II (Cf. AAS 56 [1964] 1015). Sobre la génesis y desarrollo de este nuevo título mariano, Cf.: J.A. de Aldama, Mater Ecclesiae: EphMar 14 (1964) 443-50; C. Vollert, María y la Iglesia: «Mariología», 921-66: 931-34; L. Ciappi, «Mater Ecclesiae»: Div 9 (1965) 447-63; C. Pozo, o.c., 56-64 (bibliogr.); J. Galot, o.c., 353-78: 361-67. Más bibliografía al respecto, infra, ofrecemos nn. 213.215. 
y de los cristianos, de la Cabeza y del Cuerpo: Su seno virginal fue como «el tálamo nupcial, donde el Esposo» Cristo «se hizo Cabeza de la Iglesia», uniéndose allí a ésta para devenir «así el Cristo total, Cabeza y Cuerpo» ${ }^{212}$. De ambos es, pues, Madre María: Devenida entonces plenamente Madre corporal de la Cabeza, Cristo, también fue inicialmente Madre espiritual del Cuerpo y de sus miembros, los cristianos. Una maternidad eclesial consumada, por lo demás, «junto a la cruz de Jesús», cuando éste consignó a «su Madre» por hijo «al discípulo amado», y a éste por «su Madre» a la suya (Jn 19,25-27). Si al nivel histórico debió de ser ése un gesto de indecible amor de Jesús tanto para con su discípulo - ¿qué hijo único no es celoso de su madre? - como para con su Madre, asegurándole un fiel protector para el futuro, al nivel de la redacción joannea envuelve aquel gesto un profundo significado eclesiológico y mariológico: La «mujer» María es símbolo de la Sión mesiánica, que recibe por "hijo» suyo a la -en "el discípulo amado» simbolizada - comunidad de los creyentes en Cristo, la cual recibe asimismo de Jesús a María como «Madre suya» ${ }^{213}$; así devino plenamente María lo que ya desde su creyente «sí» fue (Cf. supra), Madre de la Iglesia. Lo que significa: La maternidad eclesial de María y la filiación mariana de la Iglesia son -en la concepción de Juan - un regalo de Jesús o, más exactamente, el primer don y mérito de Cristo crucificado. Pues a Él se debe el que María, no sólo «miembro excelentísimo y enteramente singular de la Iglesia» sino también «tipo y modelo acabadísimo de la misma en la fe y en la caridad» ${ }^{214}$, deviniese también Madre suya: «Nuestra Madre en el orden de la gracia» ${ }^{215}$. Y, en cuanto tal, mediadora de todo don salvífico ${ }^{216}$. Esa misión, en efecto, carac-

212. San Agustín, In Ioan. Ev. tract. 8,4; In Ep. Ioan. tract. 1,2; Cf. Enarr. in Ps 148,8; Serm. Denis 12,2; Serm. 91,7; 192,2. 213. Así con: F.-M. Braun, La Mère des fidèles, Tournai-Paris 221954, 77-129; Id., Jean le Théologien, III, 2, Paris 1972, 108-15; P. Gächter, 'María en el Evangelio, Bilbao 1959, 354-57; M. Thurian, o.c., 231-35; A. Feuillet, Les adieux du Christ à sa Mère (Jn 19,25-27) et la maternité spirituelle de Marie: NRTh 86 (1964) 469-89; Id., $L$ 'heure de la femme (Jn 16,21) et l'heure de la Mère de Jésus (Jn 19,25-27): Bib 47 (1966) 169-84. 361-80.557-73; Id., o.c., 135-37; R.E. Brown, St. John, II, 924-26 (trad. españ., 1220-23); I. de la Potterie, La verdad de Jesús, Madrid 1978, 187-219. 214. Conc. Vat. II, Const. LG 53; Cf. Ib., 63.65. A este respecto, Cf.: F. Merano, María tipo de la Iglesia santa y santificante: RET 29 (1969) 143-76; J.M. Cascante, La tipología María-Iglesia: EstMar 39 (1974) 79-100; J. Galot, o.c., 338-53. 215. Conc. Vat. II, Const. LG 61. Sobre la maternidad espiritual de María, además de la bibliografía citada (supra, nn. 211.213), Cf.: J.M. Bover, La maternidad espiritual de María en los Padres latinos: EstMar 7 (1948) 105-20; E.R. Carrol, María en el Magisterio de la Iglesia: «Mariología» 5-53: 43-47; G. Vollert, Principio fundamental de la mariología: Ib., 43187: 457-60; Id., María y la Iglesia: Ib., 921-66: 931-37; W. Sebastián, La maternidad espiritual de María: Ib., 711-59; F. Spedalieri, o.c., 53-118.227-87; J. Ibáñez-F. Mendoza, o.c., 53-73.81-86; B. de Margerie, La doctrine de la maternité spirituelle de Marie et les liturgies de l'Église catholique: EphMar 26 (1976) 201-45; A. Feuillet, o.c., 119-20.135s. 216. Cf.: Conc. Vat. II. Const. LG 58.62; K. Rahner, María, 96-106; A. Luis, Maria, omnium gratiarum mediatrix: EstMar 12 (1962) 423-94; S. Daly, o.c., («Mariología»), 255-58; A. Robichaud, María, dispensadora de todas las gracias, Ib., 805-37; A. Rivera, La mediación de María en la tradición cristiana antigua: EstMar 15 (1965) 21-48; R. Laurentin, Court traité, 153s; Maria, 131-34; M. O' Carrol, Vatican 
teriza profundamente a María. Pues mediante su creyente «sí» se humanizó el Logos divino (Cf. supra) y devino así el «sólo mediador entre Dios y los hombres» (1Tim 2,5): Aquel «hágase» de María fue el inicio de su mediación, por la que nos fue dado el Salvador y, con Él, la salvación. Mediadora de ésta, en efecto, es María al principio tanto del tiempo de Jesús (Jn 2,1-11) como del tiempo de la Iglesia (Act 1,14). El relato joanneo sobre las bodas de Caná ${ }^{217}$ muestra efectivamente, que por intercesión de «la Madre de Jesús» (Jn 2,3-5) convirtió éste la gran cantidad de agua [ca. 600 litros] en abundante «vino bueno» (Jn 2,6-10), símbolo de la salvación mesiánica ${ }^{218}$, realizando así su «primer signo» y manifestando en él «su potencia salvífica», por lo que «creyeron en Él sus discípulos» (Jn 2,11). Esta fe, por tanto, fue suscitada por el signo mesiánico de Jesús y, a la vez, provocada por la mediación de «su Madre» ${ }^{219}$, quien devino por ello intercesora del signo salvador del Hijo y mediadora de la fe salvífica de los hijos. Esa mediación desempeñó también María en los albores de la Iglesia, con cuyos miembros «perseveraba en la oración» por el prometido don del «Espíritu Santo» (Act 1,4-8.13-14), para, con Él «fortificados», iniciar su evangelizador testimonio cristológico «hasta los confines de la tierra» (Act 1,8). Así «presidió ella con su oración el comienzo de la evangelización» ${ }^{220}$ misionera de la Iglesia. Y, «asunta a los cielos..., con su múltiple intercesión continúa obteniéndonos los dones de la salvación eterna», siendo por ello «invocada en la Iglesia» como «Mediadora», por la que nos unimos «con mayor intimidad al [único] Mediador y Salvador» ${ }^{221}$, durante nuestra peregrinación hacia la patria del Reino. Como Madre de la Iglesia y Mediadora de sus miembros, en efecto, es también María protectora o guía del peregrinante Pueblo de Dios: Como Israel no podía caminar por el desierto sin la compañía de la hermana de Moisés y «su piadosa profetisa» María ${ }^{222}$, «distinguida entre todas las mujeres de aquella generación por sus buenas obras» ${ }^{223}$ y recompensadas éstas por Dios con el «don del pozo que proveía de agua en el desierto a Israel» ${ }^{224}$, tampoco es posible al nuevo Israel caminar sin María: ¡La «Familia de Dios» (Cf. Ef 2,19) no puede caminar sin su Madre! Pues por el desierto de este mundo no se puede peregrinar sin «el agua viva» del «Espíritu Santo» ${ }^{225}$, cuyo «don» fue otorgado a la Comunidad

II and Our Lady's Mediation, IrTQ 37 (1970) 24-55; J.M. Alonso, Mediación de María, mediación de la Iglesia: EstMar 25 (1975) 23-50; 26 (1976) 125-46; J. Galot, María, 375-77. 217. Jn 2,1-11; Cf.: M.J. Gruenthaner, o.c., («Mariología»), 103s; M. Thurian, o.c., 174-207; 193ss; R. Schnackenburg, Das Johannesevangelium, I 328-44: (trad. españ., $365-80$ (bibliogr.); R.E. Brown, St. John, I 97-111: 107-9 (trad. españ., 283-300: 295-98); R. Laurentin, María, 35-39; C. Pozo, o.c., 233-36; J. McHugh, o.c., 468-84; A. Feuillet, o.c., 130-34; J. Galot, o.c., 229-30.26265. 218. Cf. Am 9,13; Os 2,24; Jl 4,18; Is 29,17; Jer 31,5; 1Hen 10,19; 2 Bar 29,5. 219. Asi con: M. Thurian, o.c., 206; R.E. Brown, o.c., 102 (trad. españ., 290); A. Feuillet, o.c., 132. 220. Pablo VI, Exh. apost. EN 81. 221. Conc. Vat. II, Const. LG 62.222 . SifréNum. 106; una tradición pre-cristiana, como lo refleja la paráfrasis de $\operatorname{Tg} P I[=«$ Neophyti $1 »]$ Num 12,16. 223. TgPINúm 12,1. 224. TbTaan 9a: Str.-Bill., II 482; III 407. 225. Jn $4,11+7,37-39$. 
primitiva «por las oraciones de María» ${ }^{226} \mathrm{y}$, sin duda, por su maternal intercesión es regalado sin cesar a la Iglesia. Nada de extaño, pues, si ésta veneró siempre y venera a la Madre de Dios y Madre suya con «un culto especial» ${ }^{227}$ : Celebrando en su honor fiestas litúrgicas - Inmaculada Concepción, Maternidad divina y eclesial, Asunción...-, invocando con oraciones - particularmente el santo Rosario ${ }^{228}$ - a la «Madre de misericordia» y «dulce Vịgen María, saludando con júbilo a la reconocida como «Estrella del mar» y «Puerta del cielo», como «Reina de los cielos» y «Señora de los ángeles», no sin suplicar a la vez la «protección» de la «santa Madre de Dios». ${ }^{229}$. Piedad y devoción mariana, maravillosamente sintetizada en los inspirados y cálidos versos de un ilustre vate agustino:

Virgen que el sol más pura,

gloria de los mortales, luz del cielo, en quien es la piedad como la alteza;

los ojos vuelve al suelo,

y mira un miserable en cárcel dura, cercado de tinieblas y tristeza;

y si mayor bajeza

no conoce ni igual juicio humano

que el estado en que estoy por culpa ajena,

con poderosa mano

quiebra, Reina del cielo, esta cadena.

Virgen, en cuyo seno

halló la Deidad digno reposo,

do fue el rigor en dulce amor trocado,

si blando al riguroso

volviste, bien podrás volver sereno

un corazón de nubes rodeado;

descubre el deseado

rostro, que admira el cielo, el suelo adora,

las nubes huirán, lucirá el día;

tu luz alta, Señora,

venza esta ciega y triste noche mía.
Virgen y Madre junto,

de tu Hacedor dichosa engendradora, a cuyos pechos floreció la vida; mira cómo empeora

y crece mi dolor más cada punto; el odio cunde, la amistad se olvida; si no es de ti valida

la justicia y verdad que tú engendraste, ¿adónde hallará seguro amparo?

$Y$ pues Madre eres, baste

para contigo el ver mi desamparo.

Virgen del sol vestida,

de luces eternales coronada,

que huellas con divinos pies la luna;

envidia emponzoñada,

engaño agudo, lengua fementida, odio cruel, poder sin ley ninguna me hacen guerra a una; pues contra un tal ejército maldito, ¿cuál pobre y desarmado será parte, si tu nombre bendito, María, no se muestra por mi parte?

226. Conc. Vat. II, Const. LG 59. 227. Conc. Vat. II, Const., LG 66-67. Esas directrices conciliares sobre el culto a María han sido magistralmente explicitadas luego por Pablo VI, Exh. apost. Marialis cultus: AAS 66(1974) 113-188 (texto y trad. españ. en C. Pozo, o.c., 329-408); a este respecto, Cf. AA.VV., Culto y piedad mariana hoy. La exhortación «Marialis cultus» (EstMar 43), Madrid 1978; A. Rivera, La tradición patrística en la «Marialis cultus»: EphMar 38 (1978) 239-51. Sobre el culto a María, Cf. también: R. Laurentin, María, 158-80; M. Schmaus, Maria, culto a: SM IV 440-48 (bibliogr.); J. Ratzinger-H. Urs von Balthasar, Maria, primera Iglesia, Madrid 1982, 45-50.77-90; AA.VV., Fundamentos teológicos de la piedad mariana (EstMar 48), Madrid 1983. 228. Oración de individual y comunitaria devoción mariana, reiteradamente recomendada por los Sumos Pontífices y, con particular insistencia, por Juan Pablo II, tras haberlo hecho - con vasta y profunda exposición teológica- su predecesor Pablo VI, o.c., 42-55 (=C. Pozo, o.c., 387-400). 229. Oraciones Salve Regina, Alma Redemptoris Mater, Ave Regina coelorum y Sub tuum praesidium. 
Virgen, por quien vencida

llora su perdición la sierpe fiera, su daño eterno, su burlado intento; miran de la ribera seguras muchas gentes mi caída, el agua violenta, el flaco aliento; los unos con contento, los otros con espanto; el más piadoso con lástima la inútil voz fatiga.

Yo, puesto en ti el lloroso

rostro, cortando voy onda enemiga.

Virgen, del Padre Esposa, dulce Madre del Hijo, templo santo del inmortal Amor, del hombre escudo, no veo sino espanto.

Si miro la morada, es peligrosa; si la salida, incierta, el favor mudo, el enemigo crudo, desnuda la verdad, muy proveída de armas y valedores la mentira: la miserable vida sólo cuando me vuelvo a ti respira.

Virgen, que al alto ruego no más humilde si diste que honesto, en quien los cielos contemplar desean; como terreno puesto, los brazos presos, de los ojos ciego, a cien flechas estoy que me rodean, que en herirme se emplean.

Siento el dolor, mas no veo la mano, ni me es dado el huir ni el escudarme: quiera tu soberano Hijo, Madre de amor, por ti librarme.
Virgen, lucero amado

en mar tempestuoso clara guía, a cuyo santo rayo calla el viento; mil olas a porfía hunden en el abismo un desarmado leño de vela y remo, que sin tiento el húmedo elemento corre; la noche carga, el aite truena; ya por el cielo va, ya el suelo toca, gime la rota antena;

socorre, antes que embista en dura roca.

Virgen no inficionada

de la común mancilla y mal primero, que al humano linaje contamina; bien sabes que en ti espero dende mi tierna edad; y si malvada fuerza que me venció ha hecho indina de tu guarda divina mi vida pecadora, tu clemencia tanto mostrará más su bien crecido, cuanto es más la dolencia, y yo merezco menos ser valido.

Virgen, el dolor fiero añuda ya la lengua, y no consiente que publique la voz cuanto desea; mas oye tú al doliente ánimo que contino a ti vocea ${ }^{230}$.

230. F. García, Obras completas castellanas de Fray Luis de León, Madrid ${ }^{2} 1951,1472-74$. 
Este canto poético del exegeta y vate salmantino es sin duda fruto del mencionado culto especial a María, el cual, si honra con filial piedad y amor a la Madre, glorifica en último término también - y sobre todo- a Dios: Por alabar o ensalzar la omnipotencia salvífica y el amor del Padre que la eligió, del Hijo que la redimió, y del Espíritu Santo que la santificó. 


\section{II. «CRISTO MURIÓ POR NUESTROS PECADOS... Y FUE SEPULTADO» *}

Así comienza una de las más antiguas confesiones cristianas (1Cor 15,3-5). Y con razón. Pues la finalidad redentora de la Encarnación muestra, que ésta se orientó hacia la pasión y muerte salvíficas de Jesús ${ }^{1}$. Éstas, completadas por el culmen de la resurrección, constituyen por tanto el evento salvífico central de la «historia salutis» y, en particular, de la soteriología neotestamentaria, para la que la resurrección es la victoria del Crucificado sobre la muerte. Así lo reflejan no sólo alguno de los más antiguos himnos y confesiones cristianas ${ }^{2}$ sino también la prístina predicación apostólica ${ }^{3} \mathrm{y}$, con particular énfasis, el kérygma de Pablo centrado en "Cristo crucificado» ${ }^{4}$; por lo demás, si los cuatro Evangelios coinciden en describir el ministerio público de Jesús amenazado reiteradamente por la muerte ${ }^{5}$, para luego relatar ampliamente su drama final ${ }^{6}$, es porque en este relato - completado por el de la resurrección - culmina la historia de Jesús, siendo aquéllos, por tanto, «relatos de la pasión con prolija introducción» (M. Kähler).

\section{1. «VERDADERAMENTE SUFRIÓ Y MURIó!»}

Cf.: X. LÉON-Dufour, Passion: DBS VII 1419-92: 1479-88; M.-J. LAGRANGe, L'Évangile de Jésus-Christ, Paris 1936, 492-580; P. BENoIT, Passion et Réssurrection du Seigneur, Paris 1966, 9-262; J. BLINZLER, Der Prozess Jesu, Regensburg ${ }^{4} 1969$; Pasión de Cristo: SM V 258-64: 262s; Ch. H. DoDD, Historical tra-

* Cf.: C. Blume, o.c., 162-67; Th. Zahn, o.c., 68-74. S. Bäumer, o.c., 199-201; F. Kattenbusch, o.c., II 625-41.900-15; I. Ortiz de Urbina, o.c., 245-51; AA.VV., Il Simbolo, VII-IX, Assisi ${ }^{2}$ 1959.1952; J. Ratzinger, o.c., 230-49 (trad. españ., 244-63); H. Urs von Balthasar, El misterio pascual: MS III.2,143-265; Id., Il Nuovo Patto (Gloria 7), Milano 1977, 185-213; W. Beinert, o.c., 95-100; K. Lehmann, «Ich glaube» (Hrsg. W. Sandfuchs), Würzburg ${ }^{3} 1975$, 51-64; G. Huyghe, «La foi de l’Église», Paris 1978, 213-36; M.M. González Gil, o.c., II 3-276; Ph. Schäfer, o.c., 53-63 (trad. españ., 75-89); AA.VV., Crucificado por nuestra causa: Com 2 (1980) 7-66.

1. Cf. supra, 411-13; H. Urs von Balthasar, o.c. [MS], 143-52; M.M. González Gil, o.c., 87-89. Eso mismo subraya la ilación o secuencia entre el $3 .^{\circ}$ y $4 .^{\circ}$ artículo del Símbolo, indicando con ello que «el misterio de la Cruz no es otro que el de la Encarnación en su plenitud»: K. Barth, Dogmatik, IV. 2(Zürich ${ }^{2}$ 1964), 325. 2. Cf. Fil 2,6-11; 1Pe 2,22-25; 3,18; 1Cor 15,3-5; Rm 4,25. 3. Cf. Act $2,22-24 ; 3,13-15 ; 4,10 ; 5,30 ; 8,30-35 ; 10,39-40 ; 13,27-31 ; 17,2-3$; 26,23. 4. Cf. Gál 3,1.13; 6,14; 1Cor 1,17-25; 2,1-8; Ef 2,13-18; Fí1 2,5-11; Col 1,20-22; 2,13-14 etc. 5. Cf. Mac 3,6par; Lc 4,29; 13,31; Jn 5,16; 7,1.19.30; 8,37.59; 10,31.33.39; 11,47-

53. 6. Mc 14-15par; Jn 18-19. 
dition in the Fourth Gospel, Cambridge 1963, 21-136 (trad.españ., 33-144); El Fundador del Cristianismo, Barcelona 1975, 176-89; J. JerEMIAS, Abba, Göttingen 1966, 191-229; Theologie NT, Gütersloh 1971, 263-84 (trad.españ., 32146); J. GNILKA, Wie urteilte Jesu über seinen Tod?: «Der Tod Jesu» (QD 74), Freiburg 1976, 13-50; A. VÖGTLE, Todesankündigungen und Todesverständnis Jesu: Ib., 51-113; R. PeSCH, Das Abendmahl und Jesu Todesverständnis: Ib., 137-87; Das Markusevangelium II (HerdersThKNT, II. 2), Freiburg 1977, 318419; J. LosADA, ¿Cómo ha interpretado Jesús su muerte?: Com 2 (1980) 30-43.

La soteriología bíblica y, en particular, neotestamentaria es esencialmente histórica. En la historia, por tanto, se enmarca su epicentro: La pasión y muerte de Jesús. Esto subraya precisamente el Símbolo con la mención del Procurador romano, «bajo cuyo» gobierno en Judea tuvo lugar aquélla ${ }^{7}$, por Jesús mismo prevista y reiteradamente preanunciada:

\section{1) Previsión y anuncio ${ }^{8}$}

El trágico final no cogió a Jesús de sorpresa. ¡Al contrario! Él lo previó claramente, como necesaria consecuencia de sus gestos y palabras: La insistente acusación de practicar la magia ${ }^{9}$, transgredir el sábado ${ }^{10} \mathrm{y}$ "blasfemar» contra Dios ${ }^{11}$ era castigada por la ley judía con la pena capital ${ }^{12}$; y si Él se consideró "un profeta» ${ }^{13}$, previó también el trágico destino reservado por el Judaísmo a los profetas ${ }^{14}$. Todos esos y otros eventos muestran, por tanto, que Jesús previó su muerte y contó con ella ${ }^{15}$. No sólo eso. También anunció reiteradamente su pasión y muerte. Así lo atestiguan unánimemente los cuatro evangelistas ${ }^{16}$, tras cuya redacción pospascual pueden detectarse críticamente algunas predicciones genuinas del Jesús histórico ${ }^{17}$, consciente de ser «el Pas-

7. Cf. supra, 146 (n. 268). 439; así lo subrayan varios comentaristas del Símbolo: Rufino, San Agustín, San Pedro Cris., Cat. Romano (Cf. supra). 8. Cf. K.H. Schelkle, Die Passion Jesu in der Verkündigung des NT, Heidelberg 1949, 60-78; A. George, Le Christ, envoyé de Dieu, Paris 1961, 404-10; Comment Jésus a-t-il perçu sa propre morte?: LumVie 101 (1971) 34-59; J. Blinzler, o.c., 423-31; A. Feuillet, Les trois grandes prophéties de la passion et de la résurrection des évangiles synoptiques: RThom 67 (1967) 533-60; 68 (1968) 41-74; H.Urs von Balthasar, e.c. [MS], 197-200; J. Jeremias, Abba, 210-16; Theologie NT, 264-72 (trad. españ., 321-31); H. Schürmann, Jesu Ureigener Tod, Freiburg 21976, 26-56; M.M. González Gil, o.c., 14-20; L. Oberliner, Todeserwartung und Todesgewissheit Jesu (SBB 10), Stuttgart 1980. 9. Mc 3, 22par (Cf. Str.-Bill., I 631); Jn 8,48. 10. Mc 2,23-3,6par; Lc 13,10-17; 14,1-6; Jn 5,5-11.18; 9,1-7.13-14: Cf. E. Lohse, Sábbaton, ThWNT VII 21-29. 11. Mc 2,7par; Jn 10,30-33; Cf. 5,18. 12. M. Sanh. VII 4.7.11: Cf. Mc 3,6par; Jn 5,18; 8,59; 10,31-33; 19,7. 13. Mc 6,4par; Lc 13,33-34 (= Mt 23,37): Cf. F. Gils, Jésus Prophète d'après les Évangiles synoptiques, Louvain 1957, 9-20.28. 14. Mt 23,30-37par; Cf. 21,34-36par; 22,6. 15. Así con: J. Jeremias, Abba, 211s; Theologie NT, 265-67 (trad. españ., 323-25); H. Schürmann, o.c., 26-53. 16. Cf. Mc 2,20par; 8,31par; 9,12b (=Mt 17,12b). 31par; 10,32-34par. 45 (=Mt 20,28); Lc 13,33; 17,25; Mc 12,6-7par; 14,21-25par. 27 (=Mt 26,31); Jn 2,19; 3,14; 6,50-58; 10,11-18; 12,23-32; 13,21.38; 16,32. 17. Mc 8,31par; 9,31 par; 10,32-34par: Cf. F. Gils, o.c., 424-29; X. Léon-Dufour, Les Évangiles et l'histoire de Jésus, Paris 1963, 433-35 (trad. españ., 380-82); J. Blinzler, o.c., 424-29; A. Feuillet, a.c., 538-51; A. George, a.c., 35-41; J. Jeremias, Abba, 213-16; Theologie NT, 267-72 (trad. españ., 325-31); H. Schürmann, o.c., 55-63. 
tor» mesiánico que «da su vida por las ovejas» y cumplir la misión asignada por Dios a su mesiánico Siervo, «venido a dar la vida en rescate por todos» ${ }^{18}$. Con esa clarividencia preanunció y afrontó Jesús:

\section{2) El hecho de la Pasión}

Los cuatro evangelistas, en efecto, introducen sus relatos sobre ésta precisando que, cercana ya la fiesta de «la Pascua y de los Ázimos», las autoridades judaicas decidieron «matar» a Jesús ${ }^{19}$, a cuyo propósito criminal colaboró por soborno «Judas Iscariote, uno de los doce» discípulos ${ }^{20}$. Y el Maestro lo «sabía» (Jn 13,11). Así lo preanunció en el diálogo introductorio ${ }^{21}$ a la Cena pascual ${ }^{22}$, por Jesús celebrada «con gran deseo» $($ Lc 22,15$)$ y, con toda probabilidad, según el rito de la Pascua hebraica o memorial del paso de la esclavitud en Egipto a la libertad en la Tierra prometida ${ }^{23}$. Aquel ritual prescribe que, inmolado el cordero pascual y «preparado todo» lo necesario en «una sala grande, amueblada y adornada» ${ }^{24}$, tras el rito inicial [= «hámes»] de arrojar «toda sustancia de levadura» como eficaz signo purificador «de la levadura vieja» o del pecado ${ }^{25}$, el presidente de la asamblea - Jesús- pronunciaba sobre la $1 .^{a}$ copa la bendición y, tras «dar gracias» por la fiesta, bebía de ella y la «repartía entre» los comensales ${ }^{26}$, para lavarse luego todos las manos y servirse las «hierbas amargas» (mojadas con agua salada), en signo de

18. Jn 10,11.15; Mc 10,45par. 19. Mc 14,1-2par; Cf. Jn 11,47-53. 20. Cf. Mc 14,1011 par; Jn 13,2. 21. Cf. Mc 14,17-21 par; Jn 13,21-26. 22. Lc 22,15-20par; 1Cor 11,23-25. A este respecto, Cf.: H. Schürmann, Der Einsetzungsbericht. Lk 22,19-20 (NA XX.4), Münster 1955; AA.VV., L'Eucharistie dans le NT: LumVie 31 (1957) 9-119; P. Benoit, Exégèse et théologie, I, Paris 1961, 163-203.210-39; J. Jeremias, Die Abendmahlsworte Jesu, Göttingen ${ }^{4} 1967$ (trad. españ., Madrid 1980); Theologie NT, 274-77 (trad.españ., 334-38); L. Maldonado, La Plegaria eucarística, Madrid 1967, 152-270; H. Patsch, Abendmahl und historischer Jesus, Stuttgart 1972, 34-36.59-105; J. Betz, Fundamentos bíblico-teologicos de la Eucaristía: MS IV. 2,186-207; R. Pesch, a.c., 145-79; I.H. Marshall, Last Supper and Lord's Supper, Exeter 1980, 21-23.30113; X. Léon-Dufour, Le partage du Pain eucharistique selon le NT, Paris 1982, 93-284 (trad. españ., Madrid 1983, 105-232). En nuestro análisis seguimos el relato de Lucas, quien elaboró el texto paulino y marciano para presentar la Pascua cristiana como cumplimiento de la Pascua judía (P. Benoit, o.c., 164-200; Cf. J. Jeremias, o.c., 133-52: trad. españ., 149-79), conservando sin embargo los datos históricos sustanciales de Mc, de quien depende: Cf. J. Jeremias, o.c., 153-83; R. Pesch, Markus, II 364-73; de otro modo H. Schürmann, o.c., 15-132. 23. M. Peshaim, I-X: Cf. Str.-Bill., IV 40-76. El actual «Seder [ = ritual] de la Pascua» (Cf. P. Link, Hagadá. Manual de Pesaj, Tel-Aviv 1978; A.S. Toaff, Haggadá di Pascua, Roma ${ }^{6} 1981$ ) se remonta sustancialmente al tiempo de Jesús, quien lo usó sin duda alguna en la celebración de la Céna pascual: Cf. G. Dalman, Jesus-Jeschua, Leipzig 1922, 98-121; Str.-Bill., IV 74-76. Tras estos dos pioneros, son decisivos los brillantes análisis de J. Jeremias (Abendmahlsworte Jesu, 35-82: trad. españ., 42-92), seguido por: P. Benoit, Exégèse..., I 192-95.213-16; J. Maldonado, o.c., 161-270; J. Betz, o.c., 192s; N. Füglister, Il valore salvifico della Pascua, Brescia 1976, 123-69; V. Serrano, La Pascua de Jesús en su tiempo y en el nuestro, Madrid 1978, 14-89; I.H. Marshall, o.c., 58-80. 24. Mc 14,12-16: Cf. G. Dalman, o.c., 99-106; Str.-Bill., IV 41-54. 25. $M$. Pes. I 1-3; 1Cor 5,7-8; Cf. Jn 13,10: Str.-Bill., III 359s; J. Jeremias, o.c., 53s (trad. españ., 61s) 26. Lc 22,17-18; Cf. M. Pes. X 2; M. Ber. VIII 1: Str.-Bill., IV 61 s. 
comunión con «la vida amarga de nuestros padres en Egipto» ${ }^{27}$. Luego se escanciaba la $2 .^{a}$ copa, y el presidente de la asamblea - Jesús- respondía homiléticamente a las preguntas formuladas por los niños o alguno de los presentes sobre las diferencias «entre esta noche y todas las otras noches» ${ }^{28}$, homilía seguida con el canto del «hallel» ${ }^{29} \mathrm{y}$ la común participación en la $2 .^{\mathrm{a}}$ copa. Seguidamente, y como purificadora preparación al rito del pan ázimo, todos por segunda vez se lavaban las manos, servicio prestado por uno de los sirvientes o -en su falta - el más pequeño de los comensales ${ }^{30}$; como ninguno de los discípulos se consideraba tal ${ }^{31} \mathrm{ni}$, por tanto, se levantaba para prestar tal servicio, lo hizo Jesús, lavándoles no ya las manos sino - igesto reservado a un esclavo pagano! - los pies ${ }^{32}$. ¡Se comprende la reacción de Pedro (Jn 13,6.8)! Pero ya era tarde: Debían aceptar la lección de humilde servicio prestada por el «Señor y Maéstro» e imitar su simbólico «ejemplo», lavándose «los pies unos a otros» ${ }^{33}$. Así purificados, realizaban ahora el rito sobre el pan ázimo: Quien presidía lo tomaba, daba gracias al Dios que «saca el pan de la tierra» $y$, con inspirado tono, pronunciaba seguidamente una amplia bendición al «Señor nuestro Dios», evocando —desde la creación hasta el exilio babilónico - las principales etapas de la historia salvífica; tras lo cual presentaba el pan ázimo a los comensales como «el pan de la aflicción» comido por los «antepasados en Egipto» y, partiéndolo, lo distribuía entre aquéllos, para comulgar todos con la pasada esclavitud egipcia; Jesús, que así lo hizo en otras ocasiones, innovó esta vez el ritual judaico cuando, «tomando [el pan] y tras pronunciar la bendición» mencionada, «lo partió y sustituyó aquellas palabras significativas por otras: ESTE [PAN] ES MI CUERPO, QUE SE DA POR VOSO-

27. M. Pes. X 3.5 (=Éx 1,14): Str.-Bill., IV 63.66. 28. M. Pes. X 4-5: Str.-Bill., IV 6769. 29. Sal 113-114; Cf. M. Pes. X 5-6: Str.-Bill., IV 68-70. 30. Cf. G. Dalman, o.c., 108s. 31. Es posible que, al menos interiormente, discutiesen todavía «sobre quién era el mayor» (Lc 22,24-27; Cf. Jn 13,12-15). Sobre la relación entre estos dos textos y su enraizamiento en la prelucana tradición de la Cena pascual, Cf.: H. Schürmann, Jesu Abschiedsrede (Lk 22,21-38), Münster 1957, 63-99; R. Schnackenburg, Das Johannesevangelium, III, Freiburg 1975, 46s (trad. españ., 68-70). 32. Jn 13,5-12a. En ese contexto histórico se enmarca este gesto de Jesús: Cf. G. Dalman, o.c., 107-9; J. Jeremias, o.c., 43.76 (trad. españ., 50.86); V. Serrano, o.c., 78; J.L. Espinel, La Eucaristía del Nuevo Testamento, Salamanca 1980, 38-42; S. Sabugal, Abbá. La Oración del Señor, Madrid 1985,362s. Aunque lavar los pies no formaba parte del ritual, sí tenía lugar cuando algún comensal - como los discípulos- entraba en la sala «con pies sucios o cansados» (G. Dalman, o.c., 108), gesto entonces realizado no ciertamente por un rabbí ni siquiera permitido a un siervo judío, sólo reservado a un esclavo pagano (Cf. Str.-Bill., II 557; J. Jeremias, o.c., 197: trad. españ., 224). En todo caso, ese gesto de Jesús tiene lugar «durante la cena» pascual (Jn 13,1-2a) y, por tanto, se encuadra perfectamente en el rito judaico del $2 .^{\circ}$ lavatorio de las manos, evocado en ese antiguo y semitizante relato joanneo: Cf. R. Bultmann, Das Johannesevangelim, Göttingen 1964, 351s; J. Jeremias, o.c., 94 (trad.españ.,104). 33. Así lo interpretan varios Padres de la Iglesia y muchos exegetas modernos: Cf. G. Richter, Die Fusswaschung im Johannesevangelium, Regensburg 1967, 11-35.249-51; P.F. Beatrice, La lavanda dei piedi, Roma 1983 , 129-221. Un detallado análisis del relato joanneo (con bibliografía especializada) ofrecen: R.E. Brown, The Gospel acc. to St. John, II, Garden City 1970, 548-72 (trad. españ., 782-819); R. Schnackenburg, o.c., III 6-53 (trad. españ., 29-75). 
TROS. HACED ESTO EN MEMORIA MÍA» ${ }^{34}$. El «pan» por Él partido cesó de significar la esclavitud egipcia, deviniendo signo sacramental de su Cuerpo sacrificado por quienes, comiéndolo, comulgan en la [anticipada] muerte expiatoria de Jesús: Así eran liberados de lo que - el pecado- radicalmente esclaviza al hombre y es raíz o causa de toda tiranía, recibiendo asimismo del «partido» Cuerpo de Jesús la fuerza para dejarse «partir» por los demás. A ese rito, cuya innovación debió impresionar profundamente a los discípulos ${ }^{35}$, seguía una gran cena, en la que entre otras cosas se comía el cordero pascual y se bebía abundante vino ${ }^{36}$; finalizada la cual, y lavadas nuevamente las manos, se escanciaba la $3 .^{a}$ copa ritual o «la copa de bendición» $(1$ Cor 10,16$)$, así designada por introducir una nueva y amplia bendición a Dios por sus gestas salvíficas y por la «alianza», con que se comprometió a hacer libre y feliz a Israel en «la Tierra» prometida, en cuya libertad y felicidad comulgan cuantos de esa copa beben. También Jesús «después de comer» la cena «tomó la [tercera] copa» y, tras pronunciar la mencionada bendición o «dando gracias» ${ }^{37}$, la repartió entre «todos» con estas innovadoras palabras: «ESTA COPA [ES] LA NUEVA ALIANZA EN MI SANGRE, QUE POR TODOS SE DERRAMA. HACED ESTO EN MEMORIA MÍA» ${ }^{38}$. Bebiendo de ella, comulgaron todos en la vida [= sangre] de Jesús, recibiendo así el característico don divino - el «perdón de los pecados» y «el Espíritu de Dios»- de la «nueva alianza» ${ }^{39}$, sellada con su expiatoria Sangre. Al prescribir, pues, Jesús celebrar el signo sacramental de su Cuerpo y de su Sangre «en memoria míą), les ordenó renovar el banquete sacrificial de su Pascua como «memorial perpetuo» no ya de la pasada esclavitud y libertad, sino de su muerte y resurrección. Así fue sustituida la Pascua júdaica por la Pascua de Jesús, el nuevo Cordero pascual sacrificado ${ }^{40}$ expiatoriamente por los pecados de todos como sufriente «Siervo de Dios» ${ }^{41}$, quien

34. Lc 22,19par. «Cuerpo» [=soma] es probable versión griega de arameo «carne» [=Bisrá]: Cf. J. Jeremiass, o.c., 191-94 (trad. españ., 216-19). 35. Así lo refleja el hecho de que al Resucitado lo reconocieron «en la Fracción del Pan» (Lc 24,30-31.35), designación de la Eucaristía en las primeras Comunidades cristianas: Cf. Act $2,42.46 .20,11 ; 1$ Cor 10,15 . 36. Un antiguo midrash judaico precisa que, «si un israelita se excede un poco esa noche, Jahveh cierra un ojo». Ignoramos - ¿quién puede saberlo? - si aquella noche lo cerró, pero sí sabemos que los discípulos se excedieron: Luego, en Getsemaní, no pudieron «velar con» Jesús ni resistir al sueño, «pues sus ojos estaban cargados» (Mc 14,40=Mt 26,43). ¡Se supone por qué! 37. Lc 22,20a (=1Cor 11,25a); Mc 14,23a=Mt 26,27a. 38. Lc 22,20b (=1Cor 11,25b); Cf. Mc 14,24 (= Mt 26,28): Is 53,11-12. 39. Jer 31,31-34; Ez 16,60-63; 36,25-29: Cf. G. Dalman, o.c., 150.157; P. Benoit, o.c., 217-19; J. Jeremias, o.c., 216-18 (trad. españ., 247s); J. Betz, o.c., 198. 40. Cf. J. Jeremias, o.c., 211-16 (trad. españ., 241-46): «Cuando usa las expresiones «esto es mi carne (sacrificial)» y «esto es mi sangre (sacrificial)», se autoconsidera probabilísimamente Jesús «el Cordero pascual» (214: trad. españ., 245), como lo entendió rectamente Pablo al escribir poco antes de «la fiesta» de la Pascua: «Nuestro Cordero pascual, Cristo, fue inmolado» (1Cor 5,7-8). Así también: F.-J. Leenhardt, Le sacrement de la sainte Cène, Neuchâtel-Paris 1948, 31.37; Id., Ceci est mon Corps, Neuchâtel-Paris 1955,24; G. Walter, Jesus, das Paschalamm des Neuen Bundes. Der Zentralgedanke des Herrenmahles, Gütersloh 1950; A.J.B. Higging, The Lord's Supper in the New Testament (StBTh 6), London 1952, 49-51. 41. Así con: G. Dalman, o.c., 155s; P. Benoit,o.c., 216-17.219; J. Jeremias, o.c., 218-23 (trad. españ., 247-54); Theologie NT, 277 (trad. españ., 337s); R. Pesch, Markus, II 358-60. 
en esa ocasión se donó a los suyos en -alimento y bebida, para introducirlos en la comunión de su anticipada muerte y «vida» nueva o resurrección ${ }^{42}$. Ese memorial de la muerte expiatoria y resurrección vivificante del Señor celebra sacramentalmente la Iglesia, siendo su Cuerpó y Sangre diario alimento de quienes anhelan configurarse con el Siervo de Jahveh y con el Señor resucitado; y por ello suplican:

Memorial de la muerte y triunfo del Señor, sacramento que al hombre el amor de Dios revela:

¡Sacia con tu Cuerpo, Jesús, nuestra hambre eterna, y con tu Sangre apaga nuestra sed de amor!

Aúnanos con tu Pan, Señor, en comunión, para que testigos tuyos seamos en la tierra: ¡Luz que ilumina y levadura que fermenta, sal que a todos sala con tu amor!

Tras este rito, se escanciaba la $4 .^{\text {a }}$ copa y se concluía la fiesta con el canto del gran «hallel», como lo hicieron Jesús y sus discípulos, quienes, «cantados los himnos, salieron hacia el Monte de los Olivos» ${ }^{43}$, preanunciándoles el Maestro la próxima defección o «escándalo» de «todos» ellos ${ }^{44}$ al llegar «la hora» de su pasión. Ésta se inició con el «pavor y angustias» mortales, por Él sufridas durante su agonía getsemaníaca ${ }^{45}$ o interior lucha oracional del Siervo sufriente por someterse a la voluntad de su «Padre» y aceptar ser «entregado en manos de los pecadores» ${ }^{46}$. Por aquella oración insistente «confortado», fue Jesús tranquilo y resuelto - «ivamos!»- hacia la muerte, afrontando con serenidad señoril su prendimiento ${ }^{47}$ por «gente» armada y capitaneada por quien - Judas- «le entregó» hipócritamente «con un beso», no resistiendo Jesús a los que «le echaron mano y sujetaron» e impidiendo ser defendido con «la espada» por sus discípulos, «para que se cumplieran las Escrituras» referentes sin duda al Siervo sufriente, que «no se resistió ni se retiró» sino «se dejó llevar como un cordero al matadero» e, indefenso, "por nuestras rebeldías fue entregado a la muerte» ${ }^{48}$, siendo asimismo - como éste- abandonado Jesús por sus discípulos, quienes «dejándole huyeron todos» ${ }^{49}$. Solo,

42. Cf. P. Benoit, o.c., 220s; J. Jeremias, o.c., 223-29 (trad. españ., 254-61). 43. Sal 114118 (M. Pes. X 7); Mc 14;26par; Jn 18,1: Cf. J. Jeremias, o.c., 246-52 (trad. españ., 281-87). 44. Mc 14,26-31par; Cf. Jn 13,36-38. 45. Mc 14,36-42par; Jn 12,23-28: Cf. P. Benoit, Passion..., 9-32; X. Léon-Dufour, a.c., 1458s; M. Galizi, Gesù nel Getsemani, Zürich 1972; R. Pesch, Markus, II 285-96; A. Feuillet, L'agonie de Gethsémani, Paris 1977; S. Sabugal, Abbá..., 721. 46. Mc 14,35.41 (= Mt 26,39.41): Is 53,8-12. Así con M. Galizi, o.c., 76-77.291; A. Feuillet, o.c., 200-6. 47. Mc 14,43-52par; Jn 18,2-11: Cf. P. Benoit, Passion, 33-59; X. Léon-Dufour, a.c., 1459s; J. Blinzler, o.c., 73-101; R. Pesch, o.c., 397-404. 48. Mc 14,4449par: Is 50,5+53,7.8. Esa referencia de «las Escrituras» a la profecía sobre el Siervo sufriente se impone irresistiblemente por la previa y clara alusión de Jesús a la misión de Siervo (Mc 10,45 [ = Is 53,10-12]; 14,24par = Is 53,12): Cf. J. Jeremias, Abba, 209s. 227s; Theologie NT, 277-79 (trad. españ., 337-39); R. Pesch, o.c., 163s. 359. 49. Mc 14,50 (=Mt 26,56b). Ese abandono de Jesús por «todos» sus discípulos evoca el preanunciado del Siervo sufriente por «todos nosotros», pues «cada uno se marchó por su camino» (Is 53,6 ). 
por tanto, afrontó seguidamente un proceso ante el Sanedrín o tribunal judaico, durante el cual, como Siervo sufriente no fue defendido por nadie - «de su causa, ¿quién se ocupa?»- ni «respondió» a las acusaciones (Cf. Is 53, 7.8), hasta que, por falta de testigos concordes contra Él, fue invitado por «el sumo Sacerdote» a identificarse o no con «el Mesías, el Hijo del Bendito», juzgando «todos» su afirmativa respuesta — « iLo soy!»- como una «blasfemia» digna «de muerte» ${ }^{50}$. Nada de extraño, pues, si seguidamente fue objetó de burla y escarnio por quienes le «escupieron» y «abofetearon» como a un falso profeta, cumpliendo sin embargo lo predicho sobre el Siervo sufriente, por ello devenido «sin apariencia ni presencia» o «de aspecto despreciable y desecho de los hombres» ${ }^{51}$. Desechado asimismo por la triple negación del versátil Pedro, quien con su reiterado «no lo conozco» devino paradigma de todo discípulo apóstata, pero reconoció «al canto del gallo» su pecado y - itambién en esto es modelo! — «rompió a llorar» ${ }^{52}$. Lo que naturalmente no frenó la marcha de los eventos. Pues el tribunal judaico decidió aplicar su previa sentencia contra Jesús y, a este fin, «lo entregaron a Pilato» para ser por él procesado y condenado no sólo como un seudo-Mesías revolucionario del «pueblo», sino también como adversario del debido «tributo al César»: ¡La previa condena por el delito de lesa majestad divina fue trastocada en acusación de lesa majestad romana! Jesús, sin embargo, calló: Como el Siervo sufriente «no abrió la boca» (Is 53,7), tampoco Él «respondió algo» a las acusaciones, de modo que «admirado» por ello el procurador y convencido de no ser un peligro para el estado, decidió desembarazarse del caso, remitiéndolo primero a la «jurisdicción de Herodes»y, tras fallar este intento, proponiendo su canjeo por el sedicioso y «encarcelado Barrabás»: ¿Éste o Jesús? Estaban ante una alternativa. Y fallaron a favor del jefe zelota, fanatizando al pueblo - ila masa es fanatizable! - para exigir de Pilato la «crucifixión» de Quien, «según nuestra ley, debe morir, porque se hizo hijo de Dios». Un requerimiento reforzado seguidamente por la amaneza de acusarle - en caso contrario-a Tiberio, pudiendo perder así el honorífico título «amicus Caesaris»y, con ello, su misma carrera o puesto: ¡Habían tocado el punto débil del cobarde procurador! Quien, naturalmente, conservó su honor y puesto, al precio del

50. Mc 14,53-64par: Cf. P. Benoit, Jésus devant le Sanhedrin: «Exégèse et théologie», I 290311: o.c., 109-132; X. Léon-Dufour, a.c., 1461-67; J. Blinzler, o.c., 101-244; S. Sabugal, Christós, Barcelona 1972, 101-110; R. Pesch, o.c., II 424-46; A. Strobel, Die Stunde der Wahrheit (WUNT 21), Tübingen 1980, 5-94. La sentencia del Sanedrín recayó no sobre la dignidad mesiánica de Jesús, pretensión no castigada por el derecho judaido (contra J. Blinzler, o.c., 151s y otros autores), sino sobre su presunta filiación divina o pretensión de «llamar a Dios su Padre» [ = Abbá] natural (Jn 5,18; Cf. Mc 12,6par; 14,36par), incurriendo con ello en una egolatría (Cf. Jn 5,18; 10,33) y blasfemia (Jn 10,33) condenada por la ley (M. Sanh. VII 4; Cf. Jn 19,7): Cf. S. Sabugal, Christós, 109s. P. Benoit, Exégèse..., I 288; Ch.H. Dodd, El Fundador..., 185s. 51. Mc 14,65par: Is 50,6-7+53,2-3; Cf. P. Benoît, Les outrages à Jésus Prophète (Mc 14,65par): «Neotestamentica et Patristica» (Fs. O. Cullmann), Leiden 1962, 92-110: 96.105s; S. Sabugal, Christós, 111, n. 139. 52. Mc 14,66-72par; Jn 18,25-27: Cf. P. Benoit, Passion..., 61-86; Ch. H. Dodd, Historical tradition..., 83-88 (trad. españ., 94-99); R. Pesch, Markus, II 446-53. 
«Rey de los judíos»: Satisfizo la petición criminal de los acusadores, librando «a Barrabás» y, «tras flagelarle» bárbaramente, entregándoles «a Jesús para que fuera crucificado» ${ }^{53}$ : El Siervo sufriente, que «ofreció sus espaldas a quienes le golpeaban» $\mathrm{y}$ "fue contado entre los delincuentes», no soslayando «su rostro a los insultos y salivazos» y golpes, con que le escarnecieron seguidamente «los soldados» romanos ${ }^{54}$. ¡A la mentira y la calumnia de los acusadores judíos se sumó la sucia cobardía del juez romano en la sentencia pronunciada, durante el proceso más ilustre y vergonzoso de la historia, contra «el Justo» por excelencia! Así fue condenado Jesús a la crucifixión ${ }^{55}$, es decir, al «suplicio más cruel y terrible» (Cicerón), propio de «un esclavo» (Tácito) y ciertamente «el más miserable» (Fl. Josefo), pues «nada había entonces más ignominioso que la muerte en la cruz» (S. Agustín), reservada efectivamente por los romanos a los esclavos sediciosos así como a los más peligrosos bandidos, a los traidores de la patria y a los reconocidos revolucionarios ${ }^{56}$, siendo asimismo el crucificado considerado por el judaísmo un maldito de Dios ${ }^{57}$. Como vil Siervo y revolucionario contumaz y maldito de Dios pasó, pues, Jesús al «ser sacado para crucificarle»y, «cargando con [el trasversal de] la cruz, salió hacia el Calvario», llevando sin duda colgado «un letrero» (= Jn) con el motivo de su condena: «el Rey de los judíos» ${ }^{58}$. Su extrema debilidad indujo sin duda a los soldados a obligar al labrador «Simón Cireneo... para que cargase con su cruz», acompañándole - precisa Lucas- «mucha gente del pueblo y mujeres», que piadosamente «le condolían» ${ }^{59}$. Es del todo probable que, entre aquéllas, se encontrase María, silenciada por los Evangelistas como una mención innecesaria: El condenado tenía derecho a hablar con sus familiares y, por lo demás, quien le siguió de cerca durante su ministerio, para luego acompañarle «junto a la cruz» (Jn), difícilmente podía faltar en el «via-crucis» de su Hijo ${ }^{60}$. En todo caso, llegado Jesús «al lugar del Gólgota» del todo extenuado ${ }^{61}$; «le daban vino mirrado» con el fin de amorfinar-

53. Mc 15,1-15par; Jn 18,28-19,16a: Cf. P. Benoit, Passion..., 133-73; X. Léon-Dufour, a.c., 1467-69; J. Blinzler, o.c., 276-356; Ch. H. Dodd, Historical tradition..., 96-120 (trad. españ., 106-129); R. Pesch, Markus, II 454-68. 54. Mc 15,16-20a par; Jn 19,2-3 (=Is 50,6+53,12): Cf. J. Blinzler, o.c., 321-36; R. Pesch, 468-74; A. Strobel, o.c., 95-137. 55. Mc 15,20b-32par; Jn 19,17-27: Cf. P. Benoit, Passion, 175-206; Ch. H. Dodd, Historical tradition, 121-29 (trad. españ., 130-38); El Fundador..., 186-89; X. Léon-Dufour, a.c., 1469s; J. Blinzler, o.c., 357-71; R. Pesch, o.c., II 474-91. 56. Cicerón, In Verrem, II 5,64; Tácito, Hist. IV 11; Fl. Josefo, Bell: Jud. VII 203; San Agustín, Serm. 88, VIII 7. (Es, pues, exacto que «Jesús soportó la cruz sin temor a la ignominia»: Hebr 12,2): Cf. J. Blinzler, o.c., 357s; J. Schneider, Staurós: ThWNT VII 573s; H.R. Weber, Kreuz, Stuttgart-Berlin 1976, 13-25; E. Brandenburger, Cruz: DTNT I 358-68: 358-60. Vasta información, al respecto, ofrece M. Hengel, Mors turpissima crucis: «Rechtfertigung» (Fs. E. Käsemann), Tübingen-Göttingen 1976, 125-84; Id., La crucifixion (LD 105), Paris 1981, 11-113. 57. A raíz de Dt 21,23 (LXX): Cf. J. Blinzler, o.c., 358-59.389; M. Hengel, o.c., 106-8. 58. La «causa penae»: Cf. J. Blinzler, o.c., 362.367s. 59. Mc 15,21 par; Lc 23,27-32. 60 Así también P. Benoit, Passion, 191. 61. Es lo que sugiere Marcos, al decir que «le llevan» (Mc 15,22a), verbo por él usado para «llevar» a Jesús «enfermos» (Mc 1,32) que no se valen por sí mismos y necesitan «ser llevados» (Cf. Mc 1,32; 2,3; 7,32; 8,$22 ; 9,17$ ) por otros: Cf. P. Benoit, o.c., 194s; J. Blinzler, o.c., 364s. También es probable que, 
le un poco y atenuar sus próximos tormentos ${ }^{62}$; «pero él no lo tomó»: ¡Quería apurar con plena lucidez «el cáliz que le daba el Padre! Plenamente consciente, por tanto, «le crucificaron» hacia mediodía ${ }^{63}$, no atándole manos y pies con cuerdas sino taladrando ambos con «clavos» ${ }^{64}$ en un puesto algo «elevado» de la cruz ${ }^{65}$ y entre «dos bandidos», como del Siervo sufriente fue predicho ${ }^{66}$, atestiguando por otra parte la inscripción — «el Rey de los judíos»- trilingüe sobre la cruz, que los relatos sobre la crucifixión y muerte mesiánica de Jesús no son producto de la fe cristiana, sino redacción literaria y teológica de «un hecho histórico» ${ }^{67}$. Como sustancialmente lo es asimismo la repartición de «sus vestidos» - manto, cinturón, sandalias...- por «los soldados» así como el sorteo de su interior «túnica inconsútil», posiblemente confeccionada por su Madre ${ }^{68}$. Despojado así de todo, afrontó Jesús los terribles sufrimientos corporales -desangre, sofocamiento, espasmos...- de su larga permanencia en la cruz, -entre los cuales la «sed» devoradora, que alguien, benévolamente «se apresuró» a mitigar con «una esponja llena de vinagre»-, agudizados aquellos por la vista de «su Madre» dolorida, —que con filial providencia y amor confió al «discípulo amado»-, los «insultos» y «la burla» de los presentes así como la «injuria» de los con Él crucificados ${ }^{69}$. A todo lo cual respondió Jesús - como el Siervo sufriente - con una intercesora súplica por el perdón del «Padre, pues no saben lo que hacen» ${ }^{70}$; una súplica, por lo demás, acompañada por la salmódica oración del Justo probado y confiado en Dios [ = Sal 22], cuyo «abandono» experimentó ante «enemigos», que le «acosan como toros» o le «rodean como perros» y le «acometen como banda de malvados», confiando sin embargo en Quien «no desdeñó la miseria del pobre» y sí «escuchó cuando le invocaba», seguro por ello de «vivir para Él»: Así oró Jesús ${ }^{71} \mathrm{y}$, constatando el «total cumplimiento» de la salvífica mi-

antes de cargar a Simón con la cruz y tener que «llevar» luego a Jesús, éste cayese reiteradamente bajo el peso de aquélla: Así con P. Bennît, o.c., 191. 62. Una sólidamente atestiguada praxis romana y judaica: Cf. J. Blinzler, o.c., 365; R. Pesch, o.c., II 478. 63. A esa conclusión, tras analizar los datos de Mc 15,25 (= «a las nueve») y Jn 19,14 (= «a las doce»), llega J. Blinzler, o.c., 416-22. 64. Cf. Lc 24,40; Jn 20,20.25-27; Ev. Petri, 6,21; San Ignacio A., Esm. 1,2. Así con: P. Benoit, Passion, 195s; J. Blinzler, o.c., 361. 65. Lo suficiente para ser invitado a «descender» de ella (Mc 15,32), tener que darle de beber «vinagre» no con la mano sino «mediante una caña» (Mc 15,36par) y ser «perforado su costado» no con la espada sino «con una lanza» (Jn 19,34), siendo por tanto «elevado» (Jn 3,14; 8,28; 12,32-34): Cf. J. Blinzler, o.c., 360s. 66. Mc 15,27par: Is 53,9 ( $i$ La var. de Mc 15,28= Lc 22,37 interpretó acertadamente el significado teológico del evento histórico!). 67. Mc 15,26par; Jn 19,19-22. Así con N.A. Dahl, Der gekreuzigte Messias: «Der historische Jesus und der kerygmatische Christus» (Hrsg. H. Ristow-K. Matthiae), Berlin 2 1962, 149-69: 163; Cf. también R. Pesch, o.c., II 484. 68. Mc 15,24par; Jn 19,23s: Cf. J. Blinzler, o.c., 369; P. Benoit, o.c., 199s; Ch. H. Dodd, Historical tradition, 122s (trad. españ., 131s); R. Schnackenburg, o.c., 111317 (trad. españ., 336s); R. Pesch, o.c., II 480. Detallado análisis, al respecto, en J. Repond, Le costume de Jésus: Bibl 3 (1922) 3-14. 69. Mc 15,29-32par: Cf. P. Benoit o.c., 203-5; R. Pesch, o.c., II 486-91. 70. Lc 23,34: Is 53,12 . La autenticidad jesuana de esa súplica es indiscutible: Cf. S. Sabugal, $A b b a ́ \ldots$,.. 669. n. 465. 71. Mc 15,46par (=Sal 22,2ss). Jesús rezó sin duda -probablemente en arameo- todo el Sal 22, siendo por tanto la suya una oración de inquebrantable fe o confianza en 
sión a Él asignada, tras «gritar con gran voz» al «Padre» el salmo vespertino [ = Sal 31] con el que todo hebreo piadoso al anochecer «confía su espíritu» a Dios ${ }^{72}$, «expiró» ${ }^{73}$, rasgándose «el velo del Templo» a la muerte de Quien fue reconocido por «el centurión» romano como «un justo» inocente o «hijo de Dios» ${ }^{74}$. ¡Lo era realmente! Y porque murió, dando «su vida en rescate por todos» (Mc 10, 45par) los pecadores, desveló al Dios hasta entonces oculto tras el velo del Santuario, manifestando definitivamente y por completo su salvifico y universal amor. Esa eficacia redentora y epifánica tuvo la muerte de Jesús, cuyo cadáver «contemplaban (sic!) desde lejos unas mujeres», testigos valientes - con María y el «discípulo amado»- de su pasión y muerte ${ }^{75}$. De la cual no quedó ninguna duda. Pues, realizada la praxis del «crucifragium» o quebradura de «las piernas» por «los soldados» romanos a los dos crucificados con Jesús ${ }^{76}$, no fue necesario hacerlo con Quien «había ya muerto» y al que, para despejar toda duda, «uno de los soldados le atravesó con su lanza el costado» [izquierdò], del que «al instante salió sangre y agua» ${ }^{77}:$; $L a$ redención universal $[=$ = «angre»] y el bautismo cristiano [ = agua] brotaron así de la más sagrada llaga de Cristo crucificado! Cuyo sagrado cadáver no fue abandonado - como era frecuente- a la presa de las aves o bestias salvajes, sino recibió «al atardecer» honrosa y digna sepultura ${ }^{78}$ por iniciativa de «José

Dios salvador, su Padre. Así con: G. Dalman, Jesus-Jeschua, 185-87; P. Benoit, o.c., 220-23; J. Jeremias, Theologie NT, 184 (trad. españ., 223). R. Pesch, o.c., 494-96; Cf. también J. Scheifler, El Salmo 22 y la crucifixión del Señor: EstB 42 (1965) 5-83: 50-53. No goza de probabilidad la interpretación, que limita la oración de Jesús al Sal 22,2 y la considera sólo como una experiencia de la lejanía de Dios. Así últimamente: E. Manicardi, Gesù e la sua morte secondo Mc 15,33-37: «Gesù e la sua morte», Brescia 1984, 9-28: 25s; G. Danieli, «Elí, Elí, lemá sabactáni?»... (M̀t 27,46): Ib., 29-49: 35.45. 72. Lc 23,46: Cf. G. Dalman, o.c., 189s; P. Benoit, o.c., 224-26. 73. Hacia las tres de la tarde (Cf. J. Blinzler, o.c., 372.421s) y, probablemente, a causa de un «colapso», según recientes estudios médicos: Cf. Id., o.c., 373.381-84. 74. Mc 15,3839par; Lc 23,47: Cf. P. Benoit, o.c., 229s; J. Blinzler,, o.c., 347; R. Pesch, o.c., II 499-502. Esa inocencia de Jesús evoca irresistiblemente la del Siervo sufriente, quien «no hizo atropello ni en su boca hubo engaño» (İs 53,9). 75. Mc 15,40-41par; Cf. Jn 19,25: P. Benoit, o.c., 215-20; Ch. H. Dodd, Historical tradition, 126 (trad. españ., 135s); R. Pesch, o.c., II 503-9. 76. Jn 19,3132: Cf. J. Blinzler, o.c., 362.391. 77. Jn 19,33-34. La historicidad de este evento, atestiguado por el «válido testimonio» de «quien lo vio» (Jn 19,35) personalmente (Cf. D. Daube, Evangelisten und Rabbinen: ZNW 48 [1957] 119-26: 122s; Ch. H. Dodd, o.c., 131-35: trad. españ., 14043; J. Blinzler. o.c., 391; R.E. Brown, o.c., II 948: trad. españ., 1249; C.K. Barrett, The Gospel acc. to St. John, London $\left.{ }^{2} 1978,556\right)$ puede y es avalada por los resultados de la medicina: Cf. Ch. H. Dodd, o.c., 136 (trad. españ., 144); J. Blinzler, o.c., 382-84; R.E. Brown, o.c., II 946 s (tracl. españ., 1247s). 78. Mc 15,42-47par; In 19,38-42; Act 13,29; 1Cor 15,4: Cf. F.-M. Braun, La sépulture de Jésus: RB 45 (1936) 34-52.184-200.346-63; P. Gaechter, Zur Begräbnis Jesu: ZKTh 75 (1953) 220-25; J. Duplacy, L'ensevelissement de Jésus: Cath IV 259-62; P. Benoit,o.c., 235-62; J. Blinzler, o.c., 385-422; Id., Die Grablegung Jesu in historischer Sicht: «Resurrexit» (ed. E. Dhanis), Roma 1974, 56-107; R.E. Brown, o.c., II 956-60 (trad. españ., 1258-64); R. Schnackenburg, o.c., III 346-52 (trad. españ., 363-69). 
de Arimatea, miembro del Sanedrín» judaico y simpatizante de Jesús o «discípulo» suyo, cuyo cuerpo "osó pedir a Pilato» ${ }^{79}$; el cual, cerciorado por "el centurión» de que Jesús «había ya muerto», cedió a la solicitud y «concedió gratuitamente el cuerpo a José», quien, tras haberlo probablemente lavado y «ungido, como es costumbre enterrar entre los judíos» ${ }^{80}$, «lo envolvió en la sábana» ${ }^{81}$ por él previamente comprada y «lo depositó en un sepulcro» pétreo, cerrando su entrada con «la piedra» ${ }^{82}$. Así concluyó valientemente José el piadoso sepelio de Jesús, a la vista de algunas «mujeres» (Mc 15,47par), a quienes el judaísmo negaba la capacidad de ser testigos y cuya presencia, por tanto, no es creación literaria de los evangelistas y sí refuerza el valor histórico del evento ${ }^{83}$, sólidamente atestiguado asimismo por el prístino kérygma apostólico y confesión cristiana: «Bajaron del madero y pusieron en el sepulcro» a Jesús, quien tras morir «fue sepultado» ${ }^{84}$.

De análoga historicidad sustancial gozan asimismo los mencionados hechos sobre la pasión y muerte de Jesús ${ }^{85}$, por él afrontada en la autoconciencia no sólo de ser el Hijo de Dios sino también de tener que cumplir la salvífica misión expiatoria de su mesiánico Siervo sufriente, "venido a dar su vida en rescate por todos» ${ }^{86}$. Sobre el sólido fundamento de aquellos salvíficos eventos históricos se apoya, por tanto, nuestra profesión de fe «en Jesucristo...,

79. Una osadía, en efecto, era tal petición, por implicar pública simpatía para con el Ajusticiado y no ser normalmente aquélla concedida, pues en Palestina se otorgaba entonces a los familiares el cadáver sólo si se trataba de un ajusticiado normal, siendo rechazado en caso de ser «un criminal de lesa majestad» $\mathrm{y}$ - con más razón aún- ser solicitado por «extraños»: Cf. J. Blinzler, o.c., 387.393s; Id., a.c., 86. 80. Jn 19,39-41: Cf. J. Blinzler, o.c., 398-400; Id., a.c., 8083. 81. Sobre la reciente discusión en torno a «la Santa Sábana de Turín», Cf.: G. Ghiberti, La sepultura di Gesù, Roma 1982 (bibliogr.: 18 [n. 5]. 35,n. 41); L. Coppini.-F. Cavazzuti (dir.), La Sindone. Scienza e fede, Bologna 1983. 82. Su identificación con el tradicional «Santo Sepulcro» de Jerusalén es reconocida generalmente hoy por los especialistas: Cf. J. Blinzler, o.c., 363.401s (bibliogr.); Id., a.c., 83-85; J. Finegan, The Archeology of the New Testament, Princeton (N.J.) 1978, 164-69. 83. Así con P. Benoit, o.c., 262; J. Blinzler, o.c., 403s. Sobre la valoración de la mujer en el judaísmo, como incapaz de testimoniar, Cf. Str.-Bill., III 217.251.559. 84. Act 13,29; 1Cor 15,4a: Cf. J. Kremer, Das älteste Zeugnis von der Auferstehung Christi (SBS 17), Stuttgart 1966,36s. La expresión «murió y fue sepultado» (1Cor 15,3b-4a), usada como fórmula fija en el AT para designar la muerte y sepultura de célebres personajes históricos (Cf. Gén 35,19.29; Núm 20,1; Dt 10,6; Jces 8,32; 1Re 2,10;11,43;2Crón 35,24 etc.), con eventual mención de su sepultura (Cf. Gén 23,2-19; 25,8-10; 35,19-20; Jces 8,32; 1 Re 2,10+Act 2,29), subraya la realidad de la muerte de Jesús (J. Kremer, o.c., 37), cuyo sepulcro podían constatar los miembros de la comunidad cristiana palestinense, de la que proviene la confesión cristológica de 1Cor 15,3-5: Cf. J. Jeremias, Die Abendmahlsworte Jesu, 95-98 (trad. españ., 106-8). 85. Cf. X. Léon-Dufour, a.c., 1479-88; J. Blinzler, a.c., [SM V], 262s. 86. Así con: F. Büchsel, Lytron: ThWNT IV 341-51: 343-45; W. Wolff, Jesaja 53 im Urchristentum, Berlin 1950, 55-71; O. Cullmann, Christologie du NT, Neuchâtel-Paris 1957, 55-62; J. Giblet, Jésus, le Serviteur de Dieu: LumVie 7 (1958) 5-34: 15-29; V. Taylor, Jesus and his sacrifice, London 1955, 46-48.255s. 261s; J. Jeremias, Abba, 209-16. 227s; Theologie NT, 272-84 (trad. españ., 332-46); X. Léon-Dufour, a.c., 1482s; P. Benoit,Jésus et le Serviteur de Dieu: «Jésus aux origines de la Christologie» (ed. J. Dupont), Gembloux 1975, 111-40: 125-31; G. Gnilka, a.c., 24ss; S. Sabugal, Abba..., 571 (n. 229: bibl.). 637s. 
quien padeció bajo Poncio Pilato, fue crucificado, muerto y sepultado», derivando asimismo esta profesión de la prístina confesión cristiana (1Cor T5,3-4) en Jesús, «el Mesías» que:

2. «MURIÓ POR NUESTROS PECADOS, SEGUUN LAS ESCRITURAS, Y FUE SEPULTADO»

Cf.: K.H. SCHelkle, Die Passion Jesu, 81ss; ID., Passion Christi: LThK VIII 144-46 (bibliogr.); ID., Teología del NT, II, Barcelona 1977, 142-81; L. CERFAUX, Le Christ, 85-125; W. Michaelis, Pascho: ThWNT V 911-16; O. Kuss, Auslegung und Verkündigung, I, Regensburg 1963, 281-328; M. MEINERTZ, Teología del NT, Madrid 21966, 145-53.367-92; X. LÉON-DuFour, a.c. [DBS], 1427-79; H. URS VON BALTHASAR, e.c. [MS], 194-236; H. KeSSLER, Die theologische Bedeutung des Todes Jesu, Düsseldorf 1970; G. Delling, Der Kreuzestod Jesu in der urchristlichen Verkündigung, Berlin 1971; M.M. GONZÁLEZ GIL, o.c., II 61-230: H. URS vON BALTHASAR, Crucifixus etiam pro nobis: Com 2 (1980) 7-16. G. FrIEDRICH, Die Verkündigung des Todes Jesu im NT, Neukirchen 1982; AA.VV., Gesù e la sua morte, Brescia 1984, 9-251. (Más bibliografía en las notas siguientes).

Las cuatro amplias narraciones evangélicas sobre la pasión y muerte de Jesús no son relatos biográficos sino interpretaciones teológicas de su significado mesiánico y salvífico, redactadas por los Evangelistas o teólogos creyentes en el kérygma sobre Cristo «muerto por nuestros pecados y resucitado para nuestra justificación», para solidificar la fe de sus Comunidades en lo que «les fue transmitido» y ellos mismos «recibieron: Que Cristo murió por nuestros pecados según las Escrituras, y fue sepultado, y que resucitó al tercer día según las Escrituras, apareciéndose a Cefas y luego a los Doce» ${ }^{87}$. La luz de Pascua iluminó, pues, la redacción literaria de aquellos relatos. De ahí que su misma composición y estructura literaria refleje no la tragedia de un héroe con su desenlace final, - ise acabó! - , sino el drama del Justo ultrajado y vilmente ajusticiado, pero Vencedor sobre la muerte con el singular triunfo de la resurrección ${ }^{88}$.

87. $\mathrm{Rm} 4,25$; 1 Cor 15,3-5. Sobre la interpretación de la pasión y muerte de Jesús por los Evangelistas, Cf.: W. Hillmann, Aufbau und Deutung der synoptischen Leidensberichte, Freiburg 1941; J. Schmid, Die Darstellung der Passion Jesu in der Evangelien: GuL 27 (1954) 6-15; M. Meinertz, o.c., 145-53; X. Léon-Dufour, a.c., 1428-79: 1473ss; W. Trilling, Die Passion Jesu in der Darstellung der synoptischen Evangelien: «Lebendiges Zeugnis» 1 (1966) 28-46; A. Vanhoye, Structure et théologie des récits de la Passion dans les Évangiles synoptiques: NRTh 99 (1967) 153-63; J. Riedl, Die evangelische Leidensgeschichte und ihre theologische Aussage: BiLi 41 (1968) 70-111; G. Delling, o.c., 57-82.98-109; G. Schneider, Die Passion Jesu nach den drei älteren Evangelien, München 1973, espec., 155ss; A. Vanhoye-I. de la Potterie-Ch. Duquoc, La Passion selon les quatre Évangiles, Paris 1981; M. Limbeck (Hrsg.), Redaktion und Theologie des Passionsberichtes nach den Synoptikern, Darmstadt 1981. 88. La composición dramática se refleja ya en los relatos de Mc y Lc (Cf. X. Léon-Dufour, a.c., 1473.1476), con mayor patetismo en el de Jn (Cf. R. Schnackenburg, o.c., III 246.275: trad. españ., 269.299; R.E. Brown, o.c., II 802.858s: trad. españ., 1079.1143s). Se comprende, pues, la frecuente escenificación dramática 


\section{El drama de la Pasión}

Getsemaní, Jerusalén y el Gólgota: Tres escenarios de aquel drama escrito por los cuatro Evangelistas o primeros dramaturgos cristianos, para catequizar a sus lectores - itambién a nosotros! - sobre el significado salvífico de la pasión y muerte de Jesús. Junto con Él, - -verdadero protagonista de la acción dramática-, actúan una serie de personajes o actores representativos de la humanidad (Cf. infra), «por cuyos pecados» sufrió y murió. Pero, ¿quién es exactamente Aquél?

\section{1) El Protagonista}

A ese interrogante responden ante todo los cuatro dramas evangélicos, reflejando sus autores rasgos a) peculiares y b) comunes del único Protagonista:

a) Lo hizo por vez primera Marcos ${ }^{89}$. Sus lectores saben que, tras ser Jesús confesado «el Mesías» por Pedro, emprendió «el camino» hacia Jerusalén y jalonó esa ruta con el triple anuncio de su pasión, muerte y resurrección, consciente de ser el mesiánico Siervo sufriente «venido .... a dar su vida en rescate por todos» ${ }^{90}$. Meta final de aquel viaje hacia la victoria de su pasión y muerte fue Jerusalén, donde humilde y triunfalmente ingresó como mesiánico Descendiente de David, asegurando luego ser también «el Hijo amado» de Dios -que «los viñadores matarán»- y, en cuanto tal, «Señor» del gran monarca ${ }^{91}$. A Él precisamente «buscaban» las autoridades judías «dos días» antes de la Pascua «cómo matarle» o eliminarle, aceptando y sobornando para ello la traidora iniciativa de «Judas Iscariote, uno de los Doce» discípulos con quienes Jesús, consciente no sólo de su dignidad mesiánica y filiación divina sino también de su futura muerte redentora (Cf. supra), celebró la Cena pascual, anticipando aquélla en el banquete sacrificial de su «Cuerpo partido» y de su «Sangre derramada por todos» ${ }^{92}$ : ¡El Siervo sufriente adelantó su ho-

tanto antigua - iautos sacramentaleś - como moderna de la Pasión del Señor (Cf. Anónimo, Pasión: EUI 42,518s), en la que insistentemente se inspiró asimismo el arte cristiano: Cf. F. Zoepfl, Passion Christi. IV: Ikonographie: LThK VIII 147-51; J. Camón Aznar, La Pasión de Cristo en el arte español, Madrid 1959. 89. Cf.: C. Maurer, Knecht Gottes und Sohn Gottes im Passionsbericht des Markusevangeliums: ZThK 50 (1953) 1-38; V. Taylor, o.c., 82-163; X. Léon-Dufour, a.c., 1473s; T.A. Burkill, St. Mark's philosophie of the Passion: NT 2 (1958) 24571; J. Blinzler, a.c. [SM], 260s; J. Schreiber, Die Markuspassion, Hamburg 1969; G. Delling, o.c., 57-73; G. Schneider, o.c., 27-31.155-59; W. Schenk, Der Passionsbericht nach Markus, Gütersloh 1974; W.H. Kelber (Hrsg.), The Passion in Mark, Philadelphia 1976; D. Dormeyer, Der Sinn des Leidens Jesu (SBS 96), Stuttgart 1979 (además de los comentarios a Mc 14-15): 90. Mc 8,29.31; 9,30-31.33; 10,17.32-34.45. Sobre Mc 10,45 (=Is 53,12), Cf.: R. Pesch, Markus, II 162-64; J. Gnilka, Markus, II 103s; M. Adinolfi, Il Servo di Jhwh nel logion del servizio e del riscatto (Mc 10,45): BibOr 21 (1979) 43-61. 91. Cf. Mc 11,1-11; 12,6-8.35-37. A este respecto, Cf. S. Sabugal, Christós, 94-96. 92. Cf. Mc 14,1-2.10-11.22-24. 
ra! En realidad sonó ésta en Getsemaní, cuando, entristecido mortalmente por el «pavor y angustias», rogó insistentemente a su «Padre» natural $[=\ll \mathrm{Ab}-$ bá»] hiciese «pasar de Él la hora» de apurar «el cáliz» de la pasión y muerte, sometiéndose sin embargo a su «querer» al «llegar la hora» de aceptar el traidor beso hipócrita de Judas y entregarse inerme a su armada comitiva, «para que se cumplieran las Escrituras» referentes al Siervo sufriente, que «no se resistió ni se retiró» sino se dejó «llevar como un cordero al matadero" ${ }^{93}$. Su muerte, en efecto, había sido ya sentenciada. Lo fue formalmente, sin embargo, cuando después afirmó sin ambages — «lo soy!»— lạ pregunta del sumo Sacerdote por su dignidad mesiánica y, sobre todo, por su natural filiación divina, respuesta calificada por aquél de «blasfemia» y por «todos» sentenciada como digna «de muerte» ${ }^{94}$ : ¡El mesiánico Hijo natural de Dios es declarado blasfemo y condenado por declarar ser lo que era! Y para aplicar esa sentencia «lo llevaron a Pilato», cambiando la causa religiosa de su previa sentencia por una motivación política. Es lo que supone la inicial pregunta del procurador romano: ¿«Eres tú el Rey de los judíos?»; la evasiva respuesta — «tú lo dices»- de Jesús no lo niega ni lo afirma, consciente de ser el mesiánico descendiente de David (Cf. supra), pero no el supuesto revolucionario y rival del César. Así lo entendió Pilato, pues «admirado» de su persistente silencio ante las «muchas acusaciones» de aquellos, intentó conmutarle por el sedicioso y homicida «Barrabás»: ;El Hijo de Dios canjeado por un criminal! Ni siquiera esto logró el procurador romano. Pues tanto aquellos como «el pueblo» piden la liberación de aquél y, ante su insistencia por crucificar al inocente - «¿qué mal ha hecho?»- reconocido «Rey de los judios», cedió cobardemente Pilato: «Queriendo satisfacer (sic!) al pueblo», ordenó flagelar y crucificar a Jesús, al «Rey de los judíos» seguidamente burlado y vilmente ultrajado por «toda la cohorte» romana ${ }^{95}$. Es claro: ¡Judíos y romanos - todos los hombres- colaboraron a la crucifixión del mesiánico Hijo de Dios! Pues como tal muere Jesús en la cruz. Es lo que confirma tanto «la inscripción de su causa» como la valiente confesión del «centurión» romano: $E l$ mesiánico «Rey de los judíos» es «verdaderamente el Hijo de Dios», muerto como Siervo sufriente, derramando su «Sangre por todos» y a «todos» rescatando con el don de «su vida» ${ }^{96}$. Así describió Marcos al Protagonista de este drama redentor. Sus rasgos fundamentales fueron re-asumidos cuidadosamente por Mateo ${ }^{97}$, no sin completar el cuadro con originales interpretaciones cristoló-

93. Mc 14,32-49: Is $50,5+53,7$. Esta referencia de «las Escrituras» a la profecía isaiana sobre «el Siervo» se impone, dadas las dos previas alusiones de Mc a la misión expiatoria y vicaria del Siervo Jesús (Mc 10,45 [= Is 53,10-12]; 14,24=Is 53,12): Cf. R. Pesch, o.c., II 163-64.359. 94. Mc 14,61-64: Cf. supra, n. 50. 95. Mc 15,1-20. 96. Mc 15,26.39; 14,24; 10,45. 97. Cf. (además de los comentarios): N.A. Dahl, Die Passionsgeschichte bei Matthäus: NTS 2 (1955-56) 17-32; X. Léon.Dufour, a.c., 1474-76; W. Trilling, Der Passionsbericht nach Matthaüs: «Am Tisch des Wortes», Stuttgart 1966, 33-44; J. Blinzler, a.c., [SM], 261s; G. Schneider, o.c., 32.159-64; G. Dellin;̧, o.c., 74-76; B. Gerhardsson, Jésus livré et abandonné d'après 
gicaš. Pues dramatiza más tanto el cumplimiento del designio divino en «las Escrituras» como la responsabilidad de «todo el pueblo» en la definitiva condena del - subraya el evangelista- «Inocente» y «Mesías» Jesús ${ }^{98}$, befado asimismo por aquel como presunto y falso Justo e «Hijo de Dios», que los paganos - «el centurión y los que con él hacían guardia», representantes de la comunidad mateana- sin embargo reconocen y confiesan ${ }^{99}$. Nada de extraño, pues, si a su muerte «se rasga en dos el velo del Templo y tiembla la tierra y se parten las piedras y se abren los sepulcros y resucitan muertos», signos de haber sido hecho pedazos el viejo «eón» y haber irrumpido el nuevo con la manifestación del «día de Jahveh» en las evidentes muestras de «duelo», que la creación entera hace por el «Hijo único» ${ }^{100}$. Un duelo de las creaturas por su Creador: « Dios ha sido asesinado!» ${ }^{101}$. Pero Quien fue sepultado y su sepulcro cuidadosamente vigilado, para no ser robado su cadáver por «los discípulos» con la impostura de «haber resucitado de entre los muertos», burló aquella custodia resucitando "como lo había dicho» ${ }^{102}$. También el dramaturgo Lucas siguió de cerca a Mc con la descripción de su Protagonista, no sin enriquecer su relato con rasgos cristológicos propios ${ }^{103}$ de «un drama vivido» y comprometedor para sus lectores ${ }^{104}$. Tras el telón del escenario está «Satanás», verdadero autor de la traición de Judas, de la defección de Pedro y los demás discípulos así como del prendimiento de Jesús ${ }^{105}$, quien, consciente de su misión servicial y «tener que cumplirse en» Él lo predicho del Siervo sufriente, - «contado entre malhechores»-, fue como tal insultado y golpeado por las autoridades judaicas, despreciado y burlado por «Herodes y sus soldados», siendo asimismo befado por aquéllos como «el Mesías de Dios»o su Siervo «elegido» y, en calidad de tal, «intercedió» en la cruz por sus enemigos ${ }^{106}$ : Por los que ante Pilato le acusaron ser «el regio Mesías» revoluciona-

la Passion selon saint Matthieu: RB 76 (1969) 206-27; D. Senior, The Passion narrative in the Gospel of Matthiew: «L'Évangile selon Matthieu» (ed. M. Didier), Gembloux 1972,243-57; A. Descamps, Rédaction et christologie dans le récit matthéen de la Passion: Ib., 359-415; A. Vanhoye, o.c., 54-57. 98. Cf. Mt 26,54.56; 27,17.19.22-25: X. Léon-Dufour, a.c., 1475; G. Schneider, o.c., 160-64; A. Descamps, o.c., 402-4. 99. Mt 27,40.43 [= Sab 2,18-20+ Sal 22,9]. 54; Cf. 16,16: A. Descamps, o.c., 405; A. Vanhoye, o.c., 55s. 100. Mt 27,51-53 (=Os 8,9-10). Así con: P. Benoit, Passion, 226-28; H. Urs von Balthasar, e.c., [MS], 225. 101. Meliton S., Sobre la pascua, 96 . 102. Cf. Mt 27,57-28,6. 103. Además de los comentarios, Cf.: H. Conzelmann, Die Mitte der Zeit, Tübingen 51964, 66-86.168-88 (trad. españ., 110-36.277-80); S. Léon-Dufour, a.c., 1476-78; J. Blinzler, a.c., [SM], 262; G. Schneider, Verleugnung, Verspottung und Verhör Jesu nach Lk 22, 54-71 (StANT 22), München 1969; Id., o.c., 32-33.164-68; F. Schütz, Der leidende Christus (BWANT 89), Stuttgart 1969; G. Delling, o.c., 76-82; A. Vanhoye, o.c., 57-61; V. Fusco, La morte del Messia (Lc 23,26-49): «Gesú e la sua morte», 50-73; B. Prete, Le preghiere di Gesù al monte de gli olivi e sulla croce nel racconto lucano della passione: Ib., 75 96. 104. X. Léon-Dufour, a.c., 1476. 105. Lc 22,3.31.53: Cf. X. Léon-Dufour, a.c., 1477; G. Schneider, Verleugnung, 182 s; o.c., 165 . 106. Lc 22,27.37 [ $=$ Is 53,12]. 63-65; 23.11.34 [ = Is 53,12]. 35. «El Mesías de Dios, el Elegido» $($ Lc 23,35) es «el Siervo de Dios»: Cf. S. Sabugal, Christós, 111. La cristología del «Siervo de Dios» recorre y caracteriza la doble obra lucana (Cf. S. Sabugal, o.c., 133s; Id., Abbá..., 213) y, por tanto, su relato sobre la Pasión, característica no resaltada lamentablemente por los mencionados estudios especializados. 
rio y enemigo del César romano, exigiendo «todos» ser crucificado ${ }^{107}$. ¡Una acusación falsa! Pues el tribunal judaico lo había sentenciado previamente por confesar ser «el Hijo de Dios», muriendo efectivamente tras orar al «Padre» y entregarle confiadamente su «espíritu» ${ }^{108}$. Su muerte no fue, pues, la de un fracasado sino la del Vencedor que intercede y la del Hijo que se entrega al Padre, suscitando por ello en «el centurión» - ien los paganos! - la glorificación «a Dios» y la conversión ${ }^{109}$. Ese triunfo regio de Jesús es subrayado más dramáticamente por Juan ${ }^{110}$, quien interpretó la pasión y muerte de Jesús como «la [finalmente llegada] hora» ${ }^{111}$ de su regio-mesiánica «exaltación» ${ }^{112}$ y «glorificación» ${ }^{113}$ salvífica, cumpliéndose así en El la profecía del Siervo sufriente, que «sería exaltado y glorificado sobremanera» por devenir, mediante sus sufrimientos y muerte expiatorio-vicaria, grande y poderoso autor de «justificación» o salvación universal ${ }^{114}$. El Jesús joanneo, en efecto, aseguró que, como «la serpiente exaltada por Moisés en el desierto» fue instrumento de «vida» y «salvación» para el Israel pecador, a sí su «exaltación» -en la cruz - es fuente de «vida eterna» y «salvación» para «todo el que crea en» Él, pues revelando en aquélla el gratuito amor con que «tanto amó Dios al mundo» pecador, inauguró la derrota del «príncipe de este mundo» así como la «atracción de todos hacia» Él ${ }^{115}$ : ;Nadie - ningún pecador-puede resistirse a ese amor de Dios, manifestado por su Hijo Jesús en el trono regio de la cruz! Un trono regio y, además, glorioso. Pues como a lo largo de la historia

107. Lc 23,2.5.14.18.21.23. 108. Lc 22,70-71; 23,34.36. 109. Lc 23,47-48. 110. Además de los comentarios, Cf.: F.-M. Braun, La passion de N.S. Jésus-Christ d'après saint Jean: NRTh 60 (1933) 298-302.385-400.481-99; V. Taylor, o.c., 218-49; J.C. Fenton, The Passion acc. to John, London 1961; Ch. H. Dodd, Historical tradition, 21-139 (trad. españ., 33-147); The interpretation of the Fourth Gospel, Cambridge 1963,423-43 (trad. españ., 423-42); A. Janssens, La structure des scènes du récit de la passion en Joh XVIII-XIX: ETL 38 (1962) 504-22; E. Haenchen, Historie und Geschichte in den johanneischen Passionsberichte: Zur bedeutung des Todes Jesu, Göttingen 1967; J. Blinzler, a.c. [SM], 262; X. Léon-Dufour, a.c., 1478s; G. Schneider, o.c. [«Die Passion...»], 35-39; G. Delling, o.c., 98-109; A. Dauer, Die Passionsgeschichte im Johannesevangelium (StANT 30), München 1972, espec., 229ss; R.E. Brown, o.c., II 787-962 (trad. españ., 1061-1265); R. Schnackenburg, o.c., III 246-352 (trad. españ., 268369); I. de la Potterie, o.c., 65-87; M. Laconi, La morte di Gesù nel quarto Vangelo (Gv. 19,1737): «Gesù e la sua morte», 97-127. 111. Jn 12,$23 ; 13,1 ; 17,1$; Cf. 2,$4 ; 7,30 ; 8,20$. Sobre este tema joanneo, Cf.: G. Ferraro, L'«ora» de Cristo nel Quarto Vangelo, Roma 1974, espec., 178282 (bibliogr.); I. de la Potterie, o.c., 69-71. 112. Jn 12,32; Cf. 3,14; 8,28. A este respecto, Cf.: A. Vergotte, L'exaltation du Christ en croix dans le IV ${ }^{e}$ Évangile: ETL 28 (1952) 5-33; I. de la Potterie, L'exaltation du Fils de l'homme (Jn 12,31-36): Gr 49 (1968) 460-78; Id., o.c., 72-74; W. Thüsing, Die Erhöhung und Verherrlichung Jesu im Johannesevangelium (NA. XXI 1-2), Münster 21970, 1-37; S. Sabugal, Christós, 354-62; R. Schnackenburg, o.c., II 498-512: 499-502 (trad. españ., 490-505: 492-95). 113. Jn 12,28.33; Cf. 13,3; 17,1.5. Sobre esta temática, Cf.: J. Riaud, La gloire et la royauté de Jésus dans la passion selon saint Jean: BVC 56 (1964) 28-44; W. Thüsing, o.c., 39-249: 75-107.206-21; R. Schnackenburg, o.c., 502-10 (trad. españ., 495-503); M. Laconi, a.c., 104-8. 114. Is 52,13+53, 4-12+53, 11-12a. Sobre este transfondo deuteroisaiano del tema joanneo, Cf. W. Thüsing, o.c., 36; R. Schnackenburg, o.c., 506 (trad. españ., 499). 115. Núm 21,4-9; Jn 3,14-18; 19,39; 1Jn 4,8-10; Jn 12,31-32. 
santa «se glorificó» Dios o «glorificó su nombre» y reveló la potencia salvífica de su «gloria» salvando a su Pueblo ${ }^{116}$, prometiendo asimismo «ser glorificado en su Siervo» mesiánico al constituirle instrumento de su "salvación» para «Israel» y para «los confines de la tierra» ${ }^{117}$, con la exaltación de Jesús o su crucifixión y muerte sonó «la hora» de su inicial glorificación por el Padre: $\mathrm{Su}$ muerte -como la del «grano de trigo»- es el necesario «paso de este mundo al Padre», es decir, hacia la fecundidad de "la vida eterna» ${ }^{118}$ o de la resurrección, en la que el Padre - como lo hizo en la resurrección de Lázaro- «glorificará su Nombre» o manifestará su potencia salvífica destruyendo el señorío de la muerte ${ }^{119}$, «condenando» con ello a «este mundo» incrédulo y derrotando a su diabólico «príncipe» o "padre de la mentira» y «homicida desde el principio» ${ }^{120}$. Esta condena y aquel triunfo de Jesús se inició ya en la cruz, cuando de su corazón traspasado «salió sangre y agua»: Prueba de su verdadera muerte ( $\mathrm{Cf}$. supra) y también signo de los principales sacramentos -bautismo y eucaristía- de la Iglesia ${ }^{121}$ : ¡Del costado del «nuevo Adán» nació la nueva Eva! El drama joanneo de la pasión y muerte de Jesús es, por tanto, la exposición teológica de su exaltación y glorificación en el glorioso trono regio de la cruz, cuyo ignominioso instrumento de tortura y muerte (Cf. supra) devino - por la potencia salvífica de Dios - fuente de «vida» y salvación para cuantos, «envenenados» por «las serpientes» o pecados, «miran» o creen en el Crucificado y, «atraídos a Él» por el amor en aquélla manifestado, escapan de la tiranía del diabólico «príncipe de este mundo», por ello definitivamente «condenado» en la Cruz gloriosa de Jesús. Ese triunfo canta precisamente la Iglesia:

- « ¡Oh Cruz, árbol único en nobleza!

Jamás el bosque dio mejor tributo

en hoja, en flor y en fruto.

¡Dulces clavos! ¡Árbol dulce, en que la Vida

empieza con tan dulce Peso en su corteza!

-Cantemos la nobleza de esta guerra,"

el triunfo de la Sangre y del Madero;

y un Redentor, que en trance de Cordero, sacrificado en la Cruz salvó la tierra...» ${ }^{122}$.

Estos inspirados versos son sin duda fruto de la cálida meditación sobre la eficacia salvífica de la Cruz, en la que triunfó ya sobre «el maligno» Quien

116. Cf. Ex $15,1.6-7.11 .2$; Is 33,$10 ; 60,1-2.21 ; 62,1-2 ; 63,14 ; 66,18-19 ; \mathrm{Ez} 39,13$; etc. 117. Is 49,3-6. 118. Cf. Jn 12,23-25; 13,1: Cf. M. Laconi, a.c., 113-17. 119. Cf. Jn 12,28; 11,4.40-44. 120. Jn $12,30-31 ; 8,44$. 121. Jn 19,34. Es la interpretación de muchos Padres de la Iglesia - Cirilo J., Juan Cr., Cirilo A., Agustín, etc.- y varios autores modernos: M.-J. Lagrange, Jean 499; J. Herr, Der Durchborte, Roma 1966 (bibliogr.); H. van den Bussche, Jean, Bruges 1967,532; H. Urs von Balthasar, e.c., [MS], 227-31; R.E. Brown, o.c., II 951s (trad. españ., 1253); I. de la Potterie, o.c., 86; y otros. 122. Himno de las «laudes» en el Viernes Santo. 
con su resurrección vencerá luego a la muerte. De ahí que el teólogo Juan interprete la muerte de Jesús como su «pasar — ipascua! — de este mundo al Padre» así como el supremo testimonio del «Rey» mesiánico sobre «la verdad» personificada o revelación total del «Dios-es-amor» y del gratuito amor con que «nos amó» ${ }^{123}$. Pues fue crucificado y murió «como propiciación por nuestros pecados» y por «los de todo el mundo» pecador: «iEN ESTO SE HA MANIFESTADO EL AMOR...!»124.

b) Esta caracterización del Protagonista dramático, peculiar a cada evangelista, refleja también rasgos comunes a todos ellos así como a los restantes teólogos neotestamentarios. El Jesús que sufre y muere es, en efecto, el Mesías o el prometido Salvador regio-mesiánicò ${ }^{125}$. Asî lo subrayó el primitivo kérigma apostólico al afirmar que, con su muerte, «cumplió Dios lo preanunciado por los profetas sobre los padecimientos del Mesías» sufriente, identificado éste «con Jesús» de Nazaret, confesando por ello la comunidad cristiana «que' Cristo murió por nuestros pecados según las Escrituras...» ${ }^{126}$. Tanto el testimonio de éstas como la mencionada función expiatoria - «por nuestros pecados»- de su muerte se refieren sin duda a los sufrimientos y muerte expiatoria y vicaria del mesiánico Siérvo sufriente ${ }^{127}$, a la luz de los cuales interpretaron la pasión y muerte de Jesús los cuatro Evangelistas ${ }^{128} \mathrm{y}$, con ellos, casi todos los demás autores neotestamentarios ${ }^{129}$ así como

123. Jn 13,$1 ; 18,37 ; 14,6 ; 1$ Jn 3,$16 ; 4,8-10 ;$ Jn 3,16 . 124. 1 Jn 2,$2 ; 4,9-10$. 125. Cf. Mc 14,61-62par; 15,2.26.32par; Lc 23,39; 24,26.46; Jn 18,33-37. Bien subrayado por K.H. Schelkle, Teología del NT, II 147s. 126. Act 3,18; 17,3-4; 1Cor 15,3-4a. Sobre estos textos, Cf. S. Sabugal, Christós, 118-21.141-44; también: W. Wolff, o.c., 97s; P. Benoit, a.c. (supra, n. 85), 113s. 127. Así la generalidad de los autores: W. Wolff, o.c., 97s; O. Cullmann, o.c., 69; J. Jeremias, $A b b a, 199 \mathrm{~s}$.; P. Benoit, a.c., 113 . 128. Cf. supra, 510ss.A este respecto, Cf. también: W. Wolff, o.c., 75-78. Por lo demás, a esos relatos evangélicos sobre la pasión y muerte así como a los pre-anuncios de la misma por Jesús (Cf. supra), se suman otros (Mt 8,17; 20,28 [= Mc 10,45]; Jn 1,29; 12,38): Cf. W. Wolfi, o.c. 71-75.79-84; J. Jeremias, $A b b a, 199.201 .203 \mathrm{~s} ;$ P. Benoit, a.c., 119-21.127s. 129. Así principalmente: Act 3,13-14.26; 4,27; 8,32-35; 17,2-3; 1Cor 15,3; 2 Cor 5,21; Rm 4,25; Fil 2,6-11; Hebr 9,28; 1Pe 2,21-25; etc. A este respecto, Cf.: W. Wolff, o.c., 71-107; O. Cullmann, o.c., 63-70; J. Jeremias, Abba, 199-209; P.E. Bonnard, Le Second Isaie, Paris 1972, 280-83; P. Benoit, a.c., 112-21. A estos estudios se suman los de otros muchos autores sobre la interpretación de Is 53 en el NT: C. Maurer, a.c. (supra, n. 89); L. Cerfaux, Saint Paul et le «Serviteur de Dieu» d'Isaïe: "Récueil L. Cerfaux», II, Gembloux 1954, 439-54; D. Stanley, The theme of the Servant of Jahweh in primitive soteriology and its transposition by St. Paul: CBQ 16 (1954) 385-425; J. Road, Some NT references to Is 53: ExpT 68 (1956-57) 254-55; J. Jeremias, Polloi: ThWNT VI 536-45: 544s; Abba, 199-216.227-29; Die Abendmahlsworte Jesu, 218-23 (trad. españ., 249-54); Theologie NT, 272-84 (trad. españ., 332-46); C. Charlier, Der verherrlichte Gottesknecht: BiLit 23 (1955-56) 1904-1207; A. Nygren, Jes. 53 cls Schlüssel zum Verständnis der Taufe: «Fs. R. Herrmann», Berlin 1957, 210-13; O. Cullmann, o.c., 48-73; L. Kríntezki, Der Einfluss von Jes. 53 auf Phil 2,6-11: ThQ 139 (1959) 153-93.291-336; L. Sabourin, Rédemption sacrificielle, Bruges 1961, 223-55; E. Lohse, Märtyrer und Gottesknecht (FRLANT 64), Göttingen 21963, 220-24; M. Fischer, Vom leidenden Gottesknecht nach Jes 53: «Abraham unser Vater» (Fs. O. Michel), Leiden-Köln 1963, 116-26; X. Léon-Dufour, a.c. [DBS VI], 1429.1483s; M. Miguens, Is 53 ed il NT: «Studi G. Rinaldi», Genova 1967, 337 47; H. Cazelles, La destinée du Serviteur (Is 52,13-53,12): AS 21 (1969) 6-14; B. Gerhardsson, c $\therefore$ (supra, n. 97); P. Grelot, Les poèmes du Serviteur, Paris 1981, i39-83; D.J. Moo, The OT in ti.. Gospel Passion narratives, 
- posteriormente- los Padres de la Iglesia ${ }^{130}$, unánimes aquéllos y éstos en interpretar los sufrimientos y muerte del mesiánico «Siervo de Jahveh» en función de Jesús: El Hijo de Dios que «tomó la forma de Siervo... y se humilló en obediencia hasta la muerte... de cruz, por lo cual Dios le exaltó...» ${ }^{131}$ tras «sufrir por nosotros» y «llevar sobre el madero [de la cruz] nuestros pecados» ${ }^{132}$, para rescatarnos a «todos» ${ }^{133}$ o librarnos de la tiranía impuesta por «los ídolos» y la nomocracia, por «el pecado» y «el temor a la muerte» ${ }^{134}$, reconciliándonos asimismo con Dios ${ }^{135}$ mediante la redención universal realizada con su sacrificio expiatorio y vicario ${ }^{136}$, en cumplimiento del salvífico designio divino pre-anunciado en «las Escrituras» ${ }^{137}$. A ese designio divino res-

Sheffield 1983, 79-172; E. Franco, La morte del Servo Sofferente in Is 53: «Gesù e la sua morte», 219-36: 235s. 130. San Clemente R., ICor 16,2-14; San Justino, IApol. 50,1-51; Diál. 13; San Ireneo, Exposición, 68-70; etc.: Cf. W. Wolff, o.c., 108-42; A. Penna, Isaia, Roma 1964, 538. De ahí que algunos Padres designen a Isaías «más evangelista que profeta»: San Jerónimo, $E p .53,8$; Praef. in Is: PL 28, 825; San Agustín, De civ. Dei, XVIII 19,1. 131. Fil 2,7-9: Cf. J. Jeremias, Abba, 200.207-9 (bibliogr., 207, n. 444); L. Krintezki, a.c. (supra, n. 129); P. Benoit, a.c., 114; J. Heriban, Retto «froneîn» $e$ «kenosis». Studio esegetico su Fil 2,1-5. 6-11, Roma 1983, 145-62 (bibliogr.: 134). 132. 1Pe 2,21-25: Cf. W. Wolff, o.c., 100s; M.-E. Boismard, Quatre hymnes baptismales dans la première Épître de Pierre (LD 30), Paris 1961, 111-19; J. Jeremias, Abba, 202s; K.H. Schelkle, Die Petrusbriefe (HerdersThKNT XIII. 2), Freiburg ${ }^{4} 1976,81-86.112$ s; P. Benoit, a.c., 115s. 133. Mc 10,45 (=Mt 20,28); 1Tim 2,6; Hebr 9,12: Cf. K.H. Schelkle, Die Passion, 135-42; F. Büchsel, Lytron: ThWNT IV 343-52; J. Jeremias, Polloi: Ib., 540-45; L. Cerfaux, Le Christ, 107s; F. Prat, La théologie de saint Paul, II, Paris 1961, 227-33; G. Friedrich, o.c., 82-86. 134. Gál 5,1.13; 1Tes 1,9; Rm 6,14-15; 7,4-6; 8,2-3.15; Gál 3,10-14; 4,4-5: Rm 6,5-7.11-22; Tit 2,14; Hebr 2,14-15: Cf. S. Sabugal, Liberación y secularización, Barcelona 1978, 226-66; K.H. Schelkle, o.c., 150-66; L. Cerfaŭx, o.c., 106s; F. Prat, o.c., 266-77; AA.VV., Liberté du chrétien: LumVie 61 (1963) 5-169; F. Amiot, L'enseignement de saint Paul, Paris ${ }^{2} 1968$, 174-78. 135. Rm 5,10; 2Cor 5,18-19; Ef 2,13-18; Col 1,20: Cf. L. Cerfaux, o.c., 110-12; F. Prat, o.c., 257-66; F. Amiot, o.c., 178-81; G. Friedrich, o.c., 95-118. 136. Is 53,5.8-12= Mc $10,45+14,24$ par; Jn 10,15; 11,50-51; 13,37-38; 15,13; 17,19; 1Tes 5,10; Gál 1,4; 2,20; 3,13; 1 Cor $1,13.30 ; 5,7 ; 11,22.24 ; 15,3 ; 2$ Cor 5,14-15.21; Rm 3,25; 4,25; 8,32; 14,15; Ef 1,7; 5,2.25; Col 1,14; 1 Tim 2,6; Tit 2,14; 1 Pe 1,19; 2,21; 3,18; Hebr 2,9; 7,27; 9,12-15; 10,12-14.18; 1 Jn 2,2; 3,16; 4,10: Cf. A. Medebeille, Expiation: DBS III 112-262; K.H. Schelkle, Die Passion, 131-35.142ss; Teología NT, II 169-81; L. Cerfaux, o.c., 112-16; C. Spicq, L'Épître aux Hébreux, I, Paris 1952, 302-10; II, Paris 1953, 199-203; St. Lyonnet, Conception paulinienne de la rédemption: LumVie 7 (1958) 35-66: 39-52; Id., De notione expiationis: VD 38 (1960) 65-75.241-61; C. Bourgin, Le Christ et la purification des péchés selon l'Épître aux Hébreux: LumVie 7 (1958) 67-90; F. Prat, o.c., II 214-24; L. Sabourin, o.c., 302-63; D.M. Stanley, Christ's resurrection in pauline soteriology (AB 13), Rome 1961 (passim); F. Amiot, o.c., 157-61.166-73. 184-90.459-67; W.E. Brooks, The perpetuity of Christ's sacrifice in the Ep. to the Hebrews: JBL 89 (1970) 205-14; G. Delling, o.c., 17-35; K. Kertelge, Das Verständnis des Todes Jesu bei Paulus: «Der Tod Jesu» (QD 74), Freiburg 1976, 114-36; P. Benoit, a.c., 112-14; P. Neuzeit, Expiación: CFT I 551-61: 555-58 (bibliogr.); J. Gnilka, Redención: Ib., II 484-89: 486ss. (bibliogr.); G. Friedrich, o.c., 68-81; M. Hengel, Crucifixión, 156-203; R. Fabris, La morte di Gesù nella Lettera agli Ebrei: «Gesú e la sua morte», 177-89: 186-88. 137. Mc 8,31par; 14,21 par. 49; Lc 24,25-27.46; Jn 15,25; 19,37; Act 3,18; 8,32-35; 17,2-3; 1C.or 15,3, etc.: Cf. K.H. Schelkle, Die Passion, 81-112; Teologia NT, II 148-51; V. Taylor, o.c., 255s; X. Léon-Dufour, a.c., 1433; J. Blinzler, o.c., 425-31; Ch. H. Dodd, Conformément aux Écritures, Paris 1968, 89-105; J.M. van Gaugh, Mort pour nos péchés 
ponde, por tanto, el condicionar la salvífica liberación y redención de la humanidad a la expiatoria pasión y muerte del Siervo de Dios, a la caída «en tierra» y «muerte» del "Grano de trigo» para «dar mucho» fruto de redención (Jn 12,24): Al fracaso humano del Crucificado. ¡Por el fracaso de la cruz debió pasar Jesús, para redimir al hombre y ser luego resucitado o exaltado como Señor! ¡Por el fracaso de la propia cruz deben pasar también sus «servidores» o discípulos, cayendo «en tierra» - como «el grano de trigo»- $-\mathrm{y}$ «muriendo» para «dar mucho fruto», odiando «la propia vida en este mundo para» recuperarla transformada en «una vida eterna» (Jn $12,25 \mathrm{~s}$ ) y dar la vida al mundo, pues mientras ellos mueren el mundo recibe «la vida» (2Cor 4,12)! . El cristianismo es la religión del fracaso de la cruz y del triunfo de la Resurrección, fundada por Quien efectivamente «murió por nuestros pecados... y resucitó... según las Escrituras» (1Cor 15,3-4). También conforme a éstas fue crucificado y «murió una sola vez por los pecados el Justo por los injustos» como «Víctima de propiciación por nuestros pecados y... los de todo el mundo» ${ }^{138}$; pues al Inocente por excelencia o «a Quien no conoció pecado le hizo Dios pecado por nosotros» o le imputó nuestros pecados, «para que en Él deviniésemos justicia de Dios» o en Él se manifestase la fidelidad de Dios a su promesa de salvación gratuita ${ }^{139}$ : ¡El Justo por los injustos y el Santo por los pecadores! Por éstos fue asimismo «inmolado» Jesús como «nuestro Cordero pascual», con cuya «preciosa sangre» inocente — «ja caro precio!»- hemos «sido rescatados» de la opresión impuesta por el nuevo faraón o el diabólico «enemigo del Reino» ${ }^{140}$ : ¡Un precio realmente caro pagó Dios por nuestro

selon̉ les Écritures (ICor 15,3b): RThL 1 (1970) 191-99. 138. 1Pe 3,18+1Jn 2,1-2; Cf. Act 3,14; Mt 27,39par (=Sal 22,8; 68,10). 43 (=Sal 22,9+Sab 2,18-20). 46par (=Sal 22,2). 48par (=Sal 68,22); Lc 23,46 (=Sal 31,6a); Jn 15,25 (=Sal 68,5); 19,23-24 (=Sal 22,19). 28 (=Sal 22,16a). A este respecto, Cf.: X. Léon-Dufour, a.c., 1429s; K.H. Schelkle, Teología NT, II 15456; J.R. Scheifler, El Salmo 22 y la crucifixión del Señor: EstB 23 (1965) 5-83: 50-53; H. Gese, Psalm 22 and the NT: ZThK 65 (1968) 1-22; J.H. Reumann, Psalm 22, and the Cross: Interpr 28 (1974) 39-58; L. Jacquet, Les Psaumes, I, Gembloux 1975, 518-23. Si Sab 2,18-20 fue interpretada cristológicamente por los Padres de la Iglesia y por la liturgia en función del «Hijo de Dios» y del «Justo» por excelencia (Cf. J. Weber, Le Livre de la Sagesse [SB VI], Paris 1946, 411-15; M. Adinolfi, Il messianismo di Sap 2, 12-20: «Il Messianismo», Brescia 1966, 205-17: 212s; A. la Bonnardière, Le «juste» défié par les impies (Sap 2,12-21) dans la tradition patristique afriquaine: «La Bible et les Pères», [ed. A. Benoit], Paris 1971, 161-86), no excluyendo el análisis literario del texto su posible significado mesiánico (Cf. M. Adinolfi, a.c.; C. Larcher, Le Livre de la Sagesse, I, Paris 1983, 239-52: 250s), la tradición patrística y litúrgica de la Iglesia interpretó también -y con más frecuencia - cristológicamente el Sal 22, por «contener toda la pasión de Cristo» (Tertuliano, $A d v$. Jud. X 13; Adv. Marc. III 19,5; Cf. también: San Justino, Diál. 79,3; San Ireneo, Adv. Haer. III 19,2; IV 20,8; 33,12; Exposición, 79-80; etc.): Cf. J. Daniélou, Le Psaume 21 $[\doteq 22$ J dans la catéchèse patristique: MD 19 (1957) 17-34; J.-C. Basset, Le Psaume 22 (LXX: 21) et la Croix chez les Pères: RHPhR 54 (1974) 383-89; L. Jacquet, o.c., I 519. 139. 2Cor 5,21; Cf. Jn 8,46; 1 Jn 3,5; Hebr 7,26. 140. 1Cor 5,7; 1 Pe 1,18-19 (=1Cor 6,20); Cf. Jn 19,14.36; Apoc $5,6.12 ; 7,14 ; 12,11 ; 13,8$. A este respecto, Cf.: J. Jeremias, Amnós-Arníon: ThWNT I 34245; M.-E. Boismard, Le Christ-Agneau rédempteur des hommes: LumVie 7 (1958) 91-104; N. Füglister, Il valore salvifico de la Pascua, Brescia 1976, 51-85; F. Friedrich, o.c., 47-52. La cristolo- 
rescate! Pues el Mesías y el Siervo y el Justo y el Cordero, que por nosotros sufrió y murió, es ni más ni menos que el natural Hijo de Dios ${ }^{141}$ : «Su propio Hijo», a Quien «no perdonó sino lo entregó por todos nosotros» y, «por su muerte, nos reconcilió con Él cuando éramos enemigos» suyos, manifestándonos precisamente su indecible amor al enviarlo «como propiciación por nuestros pecados», pues «tanto amó Dios al mundo» pecador, - ia todos los pecadores!-, «que le entregó a su Hijo único» ${ }^{142}$. ¡Por mí sufrió y murió el Hijo de Dios! Esta lección fundamental debe asimilar principalmente todo espectador del drama de la Pasión, para sacar las consecuencias: ¡El amor obliga! Pues, poor lo demás, aquel drama es esencialmente comprometedor. Así lo muestra una fugaz pero atenta observación de sus principales y representativos personajes:

\section{2) Los actores}

Junto con el Protagonista de la acción dramática, actúan también en ésta una serie de personajes o actores representativos de «todos» los hombres, «por cuyos pecados» Él sufrió y murió. Todos, por tanto, pueden y deben saber «quién es quién», para situarse con acierto en ese drama y valorar sinceramente su actitud personal ante Jesús.

a) Entre aquéllos ccupa un destacado puesto Judas ${ }^{143}$, «uno de los Doce» discípulos elegidos por Jesús «para estar con Él y enviarlos a predicar» ${ }^{144}$. Formaba, pues, parte di: «la pequeña grey» del Reino (Lc 12,32), solícita y cuidadosamente «instruida» por el Maestro y devenido asimismo uno de sus «herinanos» o verdaderos familiares así como uno de los por Él «enviados»al anuncio del Reino ${ }^{145}$. Los evangelistas le asignan el- - ¡merecido! - último

gía del Cordero pascual inmolado late asimismo en los relatos sobre la institución de la Eucaristía (Mc 14,22-24par: Cf. supra, 502) y, probablemente, en Jn 19,34: La observación del Evangelista,según la cual del «traspasado costado» de Jesús «salió sangre y agua», reasume una probablemente antigua prescripción judaica, que ordena «abrir al Cordero degollado el corazón y déjese correr la sangre» (TbPes. 74b). Así con: N. Füglister, o.c., 69; H. Urs von Balthasar, e.c., [MS], 227. 141. Cf. Mt 26,63-64par; 27,40.43.54 (= Mc 15,39); Jn 19,7. 142. Rm 8,32; 5,$10 ; 1 \mathrm{Jn} 3,9-10$; Jn 3,16. Sobre la pasión y muerte de Jesús como donación o entrega «por nosotros», Cf. W. Popkes, Christus traditus (AThANT 49), Zürich 1967, 153-239 (bibliogr.); H. Urs von Balthasar, e.c.. (MS), 209-13; U. Vanni, Gesù di fronte alla morte secondo Paolo: «Gesù e la sua morte», 155-75: 167-72. R. Blázquez, Dios entregó a Jesús a la muerte: Com 2 (1980) 18-29. 143. A este respecto, Cf.: F.-M. Abel, Amour et trahison (tradendus... se tradidit): VS 59 (1939) 26-32; A. Goodier, The passion and death of our Lord Jesus Christ, New York 1944, 40-51; M. Dibelius, Judas und der Judaskuss: «Botschaft und Geschichte», I, Tübingen 1956, 272-77; K. Lüthi, Das Problem des Judas Iskariot - neu untersucht: EvTh 16 (1956) 98-114; P. Benoit, Exégèse et théologie, I 340-59; J. Blinzler, Judas Iskarioth: LThK V 1152-54 (bibliogr.); W. Popkes, o.c., 174-81; S. Brown, Apostasy and perseverance in the theology of Luke, Roma 1969, 82-97; Ch. H. Dodd, El Fundador del Cristianismo, Barcelona 1975, 178s; H.L. Goldschmidt-M. Limbeck, Heilvo'!lerverrat? Judas im NT, Stuttgart 1976; R. Pesch, Markus, II 337-40 (bibliogr.) 144. Mc 3,19par; 6,7par; 14,10.43par; Jn 6,71; 12,4; Mc 3,14. 145. Mc 4,10-11.34par; 7,17-23 (=Mt 15,15-20); 6,7-13par. 
puesto en la lista de «los Doce», designándolo asimismo «el traidor» por excelencia o «quien entregó» a Jesús ${ }^{146}$. ¿Por qué? ¿Cómo fue posible al Iscariote dar el abismal paso del "hermano» al adversario, del discípulo al traidor? ¿Qué le movió a realizar ese mostruoso gesto? A estos interrogantes se suele responder con supuestas motivaciones de trastorno psíquico, mesianismo frustrado o idealismo político. Pero los evangelistas no narran supuestos sino hechos. Y a éstos debemos atenernos. Uno de ellos es la particular confianza mostrada por Jesús para con Judas, como lo refleja el hecho de confiarle «la bolsa» o administración del dinerillo «echado en ella» por personas generosas, para «comprar lo que les hacía falta» y proveer «a los pobres» ${ }^{147}$. De su provisora iniciativa quiso, pues, depender materialmente Jesús mismo: Confiándole «la bolsa», ponía en manos del «amigo» Judas (Mt 26,50) su misma vida. ¡Pero el dinero, precisamente, corrompió al ecónomo de la comunidad apostólica! Comenzó por traicionar la confianza en él puesta por el Maestro, «robando» solapadamente las provisiones comunes a expensas, naturalmente, de los otros Doce y de «los pobres», quienes «no le preocupaban» ${ }^{148}$. Era el primer paso. Pues, «isiempre necesita el avaro!» (Horacio). Y porque la idolátrica e insaciable avaricia, — «raíz de todos los males»-, termina por «hundir a los hombres en la perdición» e inducirles incluso a «matar» a quien estorba ${ }^{149}$, — «la avaricia es un tirano crudelísimo» (Plutarco)—, el avaro Judas devino «el hijo de la perdición» al tomar la iniciativa de «contratar» (sic!) por «dinero» con las autoridades judaicas la traidora «entrega» del Maestro ${ }^{150}$. No le impidió perpetrar su monstruoso y homicida gesto la reiterada insinuación de Jesús durante el lavatorio de los pies, ni sus proféticas y severas palabras contra «el hombre» que le entregaría, ni «el bocado» de honor por Él dado finalmente «a Judas» ${ }^{151}$. Tras haber tomado éste, finalizó el «kairós» o tiempo de su conversión: ¡Entonces «entró en él Satanás» o el «homicida desde el principio» ${ }^{152}$, a quien eligió al optar contra Jesús! Cuando, en efecto, le abandonó y «salió» de la sala, «era de noche» afuera y, sobre todo, dentro de él: ¡Había rechazado «la Luz»! 153. Y corroboró ese rechazo «con un beso» hipócrita, -èl más hipócrita de la historia-, que le condujo finalmente al suicidio o fatal desenlace, común generalmente a todo traidor $\mathrm{y}$

146. Mc 3,19par; Mt 27,3; Lc 6,16; Cf. Jn 6,71; 12,4;13,2;18,2.5. 147. Jn 12,6; 13,19; Cf. Lc 8,2-3. 148. Cf. Jn 12,1-6par. Esta caracterización del avaro Judas coincide con su iniciativa de «tratar» con las autoridades judaicas (Lc 22,4) por dinero (Mt 26,15a) la entrega de Jesús, siendo por tanto «posible que Juan nos transmita una noticia histórica, no conservada en los restantes Evangelios»: R.E. Brown, St. John, I 453 (trad. españ., 712). 149. Col 3,5; 1Tim 6,9-10; Sant 4,2. 150. Jn 17,12; Mc 14,10-11 par: La iniciativa de Judas es subrayada por los tres Evangelistas (Mc 14,10par), precisando Lucas tanto el diabólico autor [-《entró Sátanás en» él一] como la motivación [-«a tratar»-] de aquélla (Lc 22,3a.4a), y subrayando Mateo la pecuniaria condición - «qué me queréis dar?»- de aquel contrato (Mt 26,15a): Esta unánime atestación de los tres Evangelistas reproduce sin duda un hecho histórico. 151. Cf. Jn 13,10-11.18; Mc $14,17-21$ par; Jn 13,26 . 152. Jn 13,$27 ; 8,44$. 153. Jn 13,$30 ;$ Cf. 3,$19 ; 11,10 ; 12,35$. 
avaro ${ }^{154}$. Ya lo dijo el Sabio: «iLa avaricia acaba por matar a quien la tiene!» (Prov 1,19). Así devino Judas «el traidor» por excelencia o paradigma de todos los traidores de Jesús y de su Iglesia, de cuantos por la «mammona» de este mundo venden - como Esaú - «la primogenitura» de su filiación divina y traicionan su fe: «¿Soy acaso yo, Señor?» (Mt 26,22). A esta pregunta deberíamos responder sinceramente, convencidos de que Judas no está lejos de cada uno de nosotros y sí personificó «quien entregó» a Jesús a todos los pecadores, «por cuyos pecados fue entregado» ${ }^{155}$. Por lo demás, Jesús y su comunidad apostólica es y será siempre acabado modelo de todo discípulo y de toda comunidad cristiana, siendo por tanto Judas una figura siempre actual: Quien «robó» las provisiones de aquélla y contradijo al Maestro, - «ino se debería hacer eso!»-, traicionando a Quien le trató como «amigo» y le lavó los pies en el intento de convertirle a su amor, es paradigma de quien -en el ámbito de la comunidad cristiana - nos roba de algún modo - el honor o el dinero, el trabajo o el tiempo... - y nos contradice y nos traiciona, poniendo incesantemente a prueba nuestro amor al enemigo y nuestra capacidad de lavarle los pies: ¿Quién es mi Judas?

b) Análoga pregunta nos plantea insoslayablemente la figura de Pedro ${ }^{156}$. En vano aseguró «no escandalizarse» de Jesús al ser «herido el Pastor y dispersarse las ovejas», declarándose dispuesto a «morir» con Él ${ }^{157}$. Luego en Getsemaní «no fue capaz de velar una hora» con el Maestro en «oración, para no entrar en la tentación» perpetrada por quien -Satanás- «había reclamado zarandearles como el trigo» ${ }^{158}$. Por eso - «ila carne es débill!»- le abandonó poco después con «todos» los discípulos y, durante el proceso ante el Sanedrín judaico, «le siguió desde lejos» solamente, -ila lejanía de la incredulidad! - , para luego negarle cobardamente ante «una criada» primero $\mathrm{y}$, por tercera vez, corroborar con «juramento» su formal apostasía: « „No conozco a ese fulano!» ${ }^{159}$. Assi devino Pedro - la «roca» fundamental de la Iglesia - paradigma de todo discípulo apóstata, de cuantos por conservar la propia vida -profesión o trabajo, honor o cultura, riqueza...negamos ante «una criada» o quienes sirven a los ídolos de este mundo nues-

154. Mc 14,45par; Mt 27,3-5; Act 1,18s. 155. Mc 3,19par +Mt 27,3; Rm 4,25+8,32. 156. Sobre la triple negación de Jesús por Pedro (Mc 14,66-72par; Jn 18,25-27), además de los comentarios y la citada bibliografía sobre la Pasión en general (supra, 498s-509) y su interpretación por los cuatro Evangelistas (supra, nn. 89.97.103.110), Cf.: G. Klein, Die Verleugnung des Petrus: ZThK 58 (1961) 285-328; E. Linnemann, Die Verleugnung des Petrus: Ib.,63 (1966) 1-32; M. Wilcox, The.Denial sequence in Mark 14,26-31.66-72: NTSt 17 (1971-72) 426-37; G. Schneider, o.c., 75-76; J. Ernst, Noch einmal: Die Verleugnung Jesu durch Petrus (Mk 14,54.66-72): «Petrus und Papst» (Hrsg. von A. Brandenburg-H.J. Urban), Münster 1977, 43-62:50-55. El relato evangélico no ocupa lamentablemente puesto alguno en la monografía de R.E. Brown-K.P. Donfried-J. Reumann, Pedro en el Nuevo Testamento, Santander 1976. 157. Mc 14,27-31par. 158. Mc 14,37-38par; Lc 22,31. 159. Mc 14,50.54.6671 par. Una apostasía formal fue la negación de Pedro, pues el verbo «arnéomai» (Mc 14,68.70par) significa «renegar de»: Cf. H. Schlier, Arnéomai: ThWNT I 469s; S. Sabugal, Christós, 185. 
tra fe y compromiso cristiano: ¡Entonces imitamos al apóstata Pedro! Pero -también en esto fue modelo- reconoció «al canto del gallo» su pecado y lo «lloró amargamente», borrando por fin su triple apostasía con la triple confesión de amor al «Señor» resucitado, sellada luego con el martirio ${ }^{160}$. Pedro apóstata primero, luego penitente y finalmente confesor: ¿Con cuál me identifico sinceramente hoy?

c) También las autoridades judías jugaron un destacado papel en el drama de Jesús. Los que trascuraban «el precepto de Dios» y «lo esencial de la Ley» - ila misericordia! - por aferrarse «a tradiciones de hombres», y por su paradosislatría o culto a la tradición sobre «el sábado» tramaron «matar» a Quien en sábado curaba o «hacía el bien» ${ }^{161}$, representan a todos los ultraconservadores de la Iglesia que, aferrados a tradiciones meramente eclesiásticas o colgados del «ayer» humano, matan o «ahogan el espíritu» (1Tes 5,19) del dinamismo evangélico y obstaculizan la marcha del Pueblo de Dios en su necesario compromiso con «el hoy» de nuestro mundo neopaganizado ${ }^{162}$. Asimismo, quienes por confesar ser «el Hijo de Dios» le declararon blasfemo y condenaron «rasgándose sus vestidos», entregándole luego a Pilato «por envidia» y acusándole con engaño como «revolucionario», para optar finalmente por el «homicida» Barrabás contra el inocente Jesús ${ }^{163}$, fueron y son paradigma no sólo de quienes por el «odio» o la envidia «matan» -como Caín a Abel-a Cristo en «su hermano» (Cf. 1Jn 3,12-15), sino también de cuantos -teólogos y exegetas- se escandalizan de la natural filiación divina de Jesús, de cuantos en su vida ordinaria o en su compromiso político y social se inspiran más en «el Capital» que en «el Sermón de la Montaña», prefiriendo la justicia a la misericordia, la violencia al diálogo, la pistola al olivo, la guerra a la paz: El Mesías revolucionario o el Siervo de Jahveh, Barrabás o Jesús: ¿Por quién de los dos opto yo hoy?

d) Precisamente ante esta alternativa nos sitúa Pilato ${ }^{164}$, responsable de-

160. Mt 26,75par; Jn 21,15-19. 161. Mt 15,2-6 (= Mc 7,2-8); 23,23 (=Lc 24,42); Mc 3,4-6par; Jn 5,5-10.18: Cf. J. Jeremias, Theologie NT, 201-4 (trad. españ., 245-48); S. Sabugal, Liberación y secularización, 157. 162. Cf. S. Sabugal, o.c., 160-63. No menor grave pecado cometen naturalmente los ultra-progresistas, que ahogan o matan «el depósito de la fe» o la Tradición de la Iglesia por un egolátrico afán de «moda nueva»: Cf. Id., o.c., 162. 163. Mc 14,6164par; Lc 23,2.5; Jn 18,30; 19,12; Mc 15,7-13par= Jn 18,39-40. 164. Las fuentes judaicas (Cf. Filón A., In Flaccum, 298-305; Fl. Josefo, Bell. Jud., II 169-75; Ant. Jud., XVIII 55-62. 64; también el pagano Tácito, Anales, XV 44) y neotestamentarias (Lc 3,1; Mc 15,1-20.43-44par; Jn 18,28-19,22.38; Act 3,13; 4,27s; 13,28; 1Tim 6,13) sobre el Procurador romano de Judea se complementan y armonizan: Cf. E. Schürer, Geschichte des judischen Volkes, I, Leipzig 1901, 48892; L. Fillon, Pilate: DB V 429-34; J. Gonzales, Pilato: EncBibl V 1110-17 (bibliogr.); J. Blinzler, o.c., 245-356: 260-73; J.P. Lemonon, Pilate et le gouvernement de la Judée, Paris 1981, 23-203 (bibliogr.). Sobre el Proceso de Jesús ante Pilato, además de estos estudios, los comentarios a los mencionados textos evangélicos así como la citada bibliografía sobre la Pasión, Cf.: H. Schlier, Die Zeit der Kirche, Freiburg 1956, 56-74; J. Blank, Die Verhandlung vor Pilatus: BZ 3 (1959) 6081; E. Haenchen, Jesus vor Pilatus; ThLZ 85 (1960) 93-102. 
cisivo de la muerte de Jesús. Pues el «crescendo» de los relatos evangélicos por suavizar su responsabilidad ${ }^{165}$ no logró borrar su bajeza y cobardía, su hipocresía y consciente crimen. Supo, en efecto, que el ilustre Reo era «inocente» y «se lo habían entregado por envidia», intentando canjearlo por un criminal; pero, ante el temor de enemistarse con el césar y perder así su puesto, _iesta motivación fue decisiva! (Cf. supra)-, se lavó hipócritamente las manos y, por «satisfacer» (sic!) a los acusadores, condenó a Jesús al suplicio de revolucionarios y traidores ${ }^{166}$. Pilato no es sólo una figura del pasado sino también del presente, - ¿no lo está en nuestro Credo?-, encarnándola cuantos ante inocentemente perseguidos y acusados nos desentendemos o lavamos las manos, cuantos por satisfacer a la gente o a un placer deponemos la cruz de cada día o rechazamos el amor al enemigo y negamos así al Siervo de Jahveh, cuantos por mantener nuestra posición social o retener el poder «crucificamos de nuevo al Hijo de Dios» (Hebr 6,6) en nuestro hermano...: ¿Quién se reconoce en el cobarde e hipócrita Pilato?

e) Junto a esos «oscuros» actores, sin embargo, no faltaron «luces» en el drama de Jesús. Lo fue Simón Cireneo, cargando con «la cruz» y llevándola «detrás de Jesús», como acabado paradigma del discípulo que «toma su cruz de cada día y le sigue» ${ }^{167}$ hasta el Gólgota de la muerte, dispuesto a sacrificar el propio e idolatrado «Isaac» sobre el «Moria» de su historia. Modelo fueron también las piadosas «mujeres», que valientemente «acompañaron» a Jesús en su via crucis y le «contemplaron» (sic!) luego en la cruz ${ }^{168}$, siendo asimismo cualificados testigos de su sepelio y, más tarde, de su resurrección, para devenir - por expreso encargo del Resucitado- las primeras portavoces de su triunfo sobre la muerte ante los cobardes «discípulos» ${ }^{169}$ : Son y serán aquéllas elevado paradigma de quienes acompañan a Jesús en el via crucis de los hermanos sufrientes, así como de todos los contemplativos del Crucificado y, también, de cuantos tras experimentar Su triunfo sobre toda realidad de sufrimiento y de muerte, lo anuncian incluso a los cobardes cristianos, que con su antitestimonio «han ocultado al Señor» resucitado ante un mundo desorientado $\mathrm{y}$ aterrorizado por el temor a la muerte, porque «ignoran dónde le han puesto") aquéllos (Jn 20,13). Sobre todos esos actores luminosos del drama de Jesús resalta - iqué duda cabe! - la figura de María, la creyente «Madre» del Crucificado, pues no se escandalizó de la cruz de su Hijo y sí se mantuvo «en pie» junto a ella cuando la «espada» del dolor «le atravesaba el alma», asociándose así activamente a su sacrificio redentor y deviniendo entonces plena-

165. Cf. Mc 15,6-10par; Mt 27,19.24; Lc 23,6-7.13-16.20.22; Jn 18,31.38; 19,4-6.12,15. Ese «crescendo» culminó (s. V-VI) en los legendarios relatos sobre la conversión (Cf. Actos de Pilato, 13 [29]; Ev. Gamaliel, 7-11) y martirio (Cf. Ev. Gamaliel, 11,44-45; Martirio de Pilato, 7) de Pilato, venerado por la Iglesia copta como un santo mártir cristiano: Cf. J. Michl, Pilatus, II: LThK VIII 505a. 166. Cf. supra, 505s. 167. Lc 23,26; 9,23par. Así con X. Léon-Dufour, a.c., 1476; I.H. Marshall, Luke, Exeter 1978, 863. Sobre el personaje, Cf. J. Blinzler, Simon v. Kyrene: LThK IX 768 (bibliogr.). 168. Lc 23,27; Mc 15,40par; Jn 19,25. 169. Mc 15,47par; 16,1-7par: Cf. S. Sabugal, Liberación, 185. 
mente «Madre» de toda la Iglesia, representada en «el discípulo amado» que — por don del Maestro agonizante- «la acogió como propiedad (sic!) suya» ${ }^{170}$ : Ella es y será modelo incomparable de cuantos creyentes siguen a Jesús hasta el final y, firmes o «de pie» junto a la propia cruz, conservan la inestimable «propiedad» de la Madre y la aman como hijos que, bajo su maternal amparo y mediación, colaboran a la redención universal realizada sobre todo por la pasión y muerte del Hijo, demostrando así no vanalizar su amor. Pues el drama de Jesús es esencialmente la cósmica representación del amor de Dios y de su Hijo al mundo pecador. En su pasión y muerte redentoras, en efecto, brilló fulgurantemente «la luz» divina sobre «las tinieblas» del odio:

\section{2. «;Se manifestó el Amor!»}

Una epifanía del amor divino fue la Encarnación del Hijo de Dios ${ }^{171}$, culminando aquel desvelamiento sin embargo en su pasión y muerte, mediante las cuales tanto el Padre como el Hijo dieron al «mundo» pecador la irrefutable prueba de su gratuito y universal amor ${ }^{172}$ :

a) La revelación del amor de Dios a los hombres, en efecto, alcanzó su cénit o insuperable cima en la pasión y muerte de su Hijo. Si tras ésta «se rasgó el velo del Templo», -que hasta entonces ocultaba la salvadora presencia y gloria de Dios [= «shekiná»] en el mundo-, fue porque con la muerte redentora de su Hijo se manifestó definitiva y plenamente el amor, con que «tanto amó Dios al mundo» pecador ${ }^{173}$ : ¡No hay velo que oculte más tiempo ese Amor! Pues «por nuestros pecados» o por amor al hombre pecador «fue entregado» Cristo por Dios, quien «no perdonó a su propio Hijo sino lo entregó por nosotros» y por todo «el mundo» sumido en el pecado ${ }^{174}$ : ¡Incomparable amor! Humanamente del todo incomprensible es, en efecto, que al Hijo «sin pecado le haya hecho Dios pecado por nosotros», imputándole nuestra infidelidad o injusticia para que, a su presencia, «deviniésemos en Él jụsticia

170. Jn 19,25-27; Lc 2,35; Conc. Vat. II, Const. LG 58. A este respecto, además de los comentarios a estos textos, Cf.: M.J. Gruenthaner, María en el NT: «Mariología» (ed. J.B. Carol), Madrid 1964, 106s; J.B. Carol, Corredención de nuestra Señora: Ib., 760-804: 772-74; C. Pozo, María en la obra de la salvación, Madrid 1974, 236-38; J. Galot, Maria, la donna nell'opera di salvezza, Roma 1984, 236-38; supra, 137.435s. (bibliogr.). 171. Cf. supra, 410s. 172. Cf.: L. Cerfaux, Le Christ, 99-104; C. Spicq, Agapè, II, Paris ${ }^{2} 1966,275-81$; III, Paris 1959, 17-24; AA.VV., L'amour de Dieu aux hommes: LumVie 44 (1959) 9-96; K. Romaniuk, L'amour du Père et du Fils dans la soteriologie de saint Paul (AB 15A), Roma 1961 (¡bella monografía!); D.M. Stanley, o.c. (supra, n. 134), 174-76. 222-24. 228-30; R. Schnackenburg, Die Johannesbriefe (HerdersThKNT XIII 3), Freiburg ${ }^{3} 1965,231-34$ (trad. españ., 256-58); F. Amiot, o.c. (supra, n. 134), 149-53; C. Spicq, L'amour de Dieu révélé aux hommes dans les écrits de saint Jean, Paris 1978; A. Feuillet, Le mystère de l'amour divine dans la théologie johannique, Paris 1972, 15-38.179-233. 173. Mc 14,38; Jn 3,16; 1 Jn 4,8.16. 174. Rm 4,25; 8,32; Jn 3,16: Cf. K. Romaniuk, o.c., 5-17. 216-25; R. Schnackenburg, Das Johannesevangelium, II 424s (trad. 
de Dios» o inocentes y justos: «jEl Justo por los injustos!» ${ }^{175}$. Y el Hijo santo por los impíos o pecadores: Con el irrefutable argumento de este hecho salvífico, - la expiatoria y vicaria muerte de su Hijo-, nos demostró el Padre su amor. Ésa es, en efecto, «la prueba de que Dios nos ama: Que Cristo, siendo aún nosotros pecadores, murió por nosotros» $\mathrm{y}$, «cuando éramos enemigos» suyos, «fuimos reconciliados con Dios por la muerte de su Hijo», pues nos «perdonó todos nuestros delitos» y «canceló nuestra desfavorable sentencia» de muerte, «clavándola en la cruz» ${ }^{176}$ : iEn la cruz de Cristo fulguró el amor de.Dios! Y en ella culminó también la autorrevelación de Dios a lo largo de la historia salvífica. Pues quien se autodefinió a Moisés como el «Dios misericordioso y clemente», revelándose luego a su Pueblo como el «Dios bueno, leal y paciente, que con su misericordia lo gobierna todo» y tiene "por estandarte el amor» ${ }^{177}$, enviando «a su Hijo al mundo... como propiciación por nuestros pecados» e irrefutable prueba de su gratuito amor a los pecadores «aún antes de haberle amado», nos «manifestó el amor que nos tiene» y despejó toda duda de lo que esencialmente le caracteriza o define: « $j D i o s$ es Amor!» ${ }^{178}$. Y ese amor compromete a todos los por Él amados. Es lo que traduce la reiterada parénesis neotestamentaria, exhortándonos a «perdonarnos como Dios nos perdonó en Cristo» y «amarnos gratuitamente como así Dios nos amó» ${ }^{179}:$;Obliga el amor de Dios!

b) También «nos apremia el amor de Cristo», muerto «por todos» en «expiación de nuestros pecados» ${ }^{180}$ o por puro amor a los pecadores, pues murió para «librarnos» de la maldad y «rescatarnos de toda iniquidad» ${ }^{181}$ así como «de la maldición de la Ley, haciéndose maldición por nosotros» al sufrir la crucifixión o ignominiosa muerte de los maldecidos de Dios, «a fin de que» heredásemos «la bendición» del «Espíritu» prometido ${ }^{182}$ : ;Para bendecir a los siervos, se hizo maldito el Hijo! Por amor también «el buen Pastor» mesiánico, que ama o «conoce a sus ovejas», dio «su vida por» ellas y «se entregó» no sólo «por su Iglesia» sino también por cada uno de nosotros, pudiendo por tanto apropiarse cada uno la exclamación de quien experimentó ese amor:

españ., 462s). 175. 2Cor 5,21; 1Pe 3,18: Cf. K. Romaniuk, o.c., 225-28. Sobre 2Cor 5,21 Cf. también: K. Kertelge, Rechtfertigung bei Paulus (NA 3), Münster ${ }^{2} 1971,99-107 . \quad 176$. Rm 5,8-10; Col 2,13-14; Cf. 1,21-22; 2Cor 5,21. A este respecto, Cf.: D.M. Stanley, o.c., 74-76; K. Romaniuk, o.c., 207-12.261-66. 177. Éx 34,6-7; Sab 15,1; Cant 2,4. Sobre el amor y misericordia de Dios en el AT, Cf. S. Sabugal, Abbá..., 627s (bibliogr.) 178. 1Jn 4,8-10.16: Cf. R. Schnackenburg, Die Johannesbriefe, 322 (trad. españ., 257); R. Prenter, Der Gott, der Liebe ist: ThLZ 96(1971) 401-13; A. Feuillet, «Dieu est amour»: EV 81 (1971) 537-48; Id., o.c., 179-233; E. Jüngel, Gott ist Liebe. Zur Unterscheidung von Glaube und Liebe: «Fs. E. Fuchs» (Tübingen 1973), 193-202; D. Dideberg, Esprit Saint et charité. L'exégèse augustinienne de 1Jn 4,8 et 16: NRTh 97 (1975) 97-109.229-50; C. Spicq, Agapè, III 270-78; Id., L'amour de Dieu..., 126-32. 179. Ef 4,32; Col 3,13; 1Jn 4,11. 180. 2Cor 5,14; 1 Cor 15,3; 1Tes 5,10; Gál 1,4; Ef 5,2; 1 Pe 3,18. 181. Gál 1,4; Tit 2,16; Cf. 2Tim 2,16; Mc 10,45par. A este respecto, Cf.: K. Romaniuk, o.c., 54-71. 182. Gál 3,13 (=Dt 21,23: LXX)-14. Sobre la crucifixión como «maldición de Dios» en el Judaísmo antiguo, Cf. supra; n. 57. 
« Me amó y se entregó por mí!» ${ }^{183}$. Lo hizo, por lo demás, en la gratuidad total. Esto, precisamente, caracteriza también al amor de Cristo. Pues «murió por los impíos» o cuando "éramos todavía pecadores», habiendo por tanto «experimentado lo que es el amor en el [gratuito] don de su vida por nosotros» ${ }^{184}$, como prueba de amarnos en nuestro pecado o allí donde jamás nadie nos amó ni por sus solas fuerzas puede amarnos: ¡La expiatoria muerte de Cristo es la plena revelación del Dios-es-Amor! Ese amor, sin embargo, compromete también a los por Él amados: $\mathrm{Si}$ «nos apremia» o urge a despojarnos de todo egoísmo y a "vivir para Quien por nosotros murió y resucitó», nos espolea también a «vivir en el amor como Cristo nos amó», a «dar la vida por los hermanos» como «Él dio la suya por nosotros», y a «amarnos unos a otros como Él nos amó» ${ }^{185}$. Sólo en este gratuito amor mutuo se revela o brilla «la luz» del amor de Dios y de su Hijo a los pecadores: ¡Sólo amando en la dimensión de la cruz, - al malvado en su maldad, al injusto en su injusticia, al impío en su impiedad, al pecador en su pecado-, se patentizan los verdaderos «discípulos» de Jesús - «ien esto lo conocerán!»-y cumplen su misión de ser «la luz del mundo» pecador o signo epifánico del amor, con que «tanto le amó [y ama] Dios» ${ }^{186}$. De ese amor participan ya los bautismal y existencialmente asociados a Cristo:

\section{3. «Configurados» a su pasión y muerte}

La pasión y muerte de Jesús no fue sólo un histórico evento salvífico del pasado: Se prolonga en los miembros de su Cuerpo místico, ya bautismal y 'luego' existencialmente asociados a la Cabeza en sus sufrimientos y crucifixión, en su muerte y sepultura ${ }^{187}$.

183. In 10,11.14-15; Ef 5,25; Gál 2,20; Cf. Ef 5,2; Gál 1,4. A este respecto, Cf.: D.M. Stanley, o.c., 228-30; K. Romaniuk, o.c., 36-52. 184. Rm 5,6-8; 1Jn 3,16a. 185. 2Cor 2,14-15; Ef 5,2; $1 \mathrm{Jn} 3,16$; Jn 13,34; Cf. 15,12-14. La agradecida alabanza al amor de Dios por todos los hombres, manifestado en su Hijo encarnado, muerto y resucitado, compendia y traduce fielmente la devoción y culto al Sagrado Corazón de Jesús, estimulada por San Juan Eudes (a. 1601-1680) y por Sta. Margarita María Alacoque (a. 1647-1690), recomendada por los Papas (León XIII, Enc. Annuum Sacrum: AAS 31 [1899] 646-51; Pío XI, Enc. Miserentissimus Redemptor: AAS 20 [1928] 165-78; Id., Enc. Caritate Christi: AAS 24 [1932] 177-94; Pío XII, Enc. Haurietis aquas: AAS 48 [1956] 309-53) como «summa religionis» (Pío XI y Pío XII), siendo asimismo objeto de reflexión teológica y mística por los teólogos de la Iglesia. Además de los artículos generales sobre el Corazón de Jesús y su devoción (J.-V. Bainel, DThC III 271-351; J. Stierli-A. van Rijen, LThK V 289-94 [bibliogr.]; A. Tessarolo, DE 492-99: bibliogr.), Cf.: J. V. Bainel, La dévotion au SacréCoeur de Jésus, Paris 1906 (trad.españ., Barcelona 1922); F. Alcañiz, Devoción al Corazón de Jesús, Granada 1929; J. Galot, Le Coeur du Christ, Bruges 1953 (trad.españ., Bilbao 1963); AA.VV., La encíclica «Haurietis aquas». Comentarios teologicos, Madrid 1958; AA.VV., Cor Iesu, I-II, Roma 1959; K. Rahner, ET III 357-92; VII 517-46; H. Urs von Balthasar, El corazón del mundo, Barcelona 1968. 186. Cf. $1 \mathrm{Jn} 1,7+4,8.16+$ Jn 8,12; Jn 13,34-35; Mt 5,14-16. 187. Rm 6,2-11; 8,17 [=«consufrir»]; 6,6+Gál 2,19 [=«concrucificado»]; 2Tim

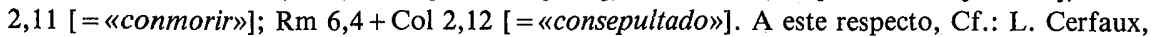
Le Chrétien dans la théologie de saint Paul (LD 33), Paris 1962, 309-14; F. Amiot, o.c., 391-94. Para el análisis de Rm 6,1-11: Cf. M.-J. Lagrange, Épitre aux Romains, Paris 1950, 142-49; R. 
1) «Si sufrimos con Él...»

La existencia del cristiano está marcada -más que la de cualquier hombre - por la realidad del dolor o «los sufrimientos del tiempo presente» ${ }^{188}$. Pues al común e insoslayable dolor humano debe soportar aquél la tribulación, injuria y persecución «por causa de la Palabra» o «de la justicia», por «causa de Cristo» o «del Reino» ${ }^{189}$. ¿Qué sentido tiene el dolor cristiano?

a) El mal y, en particular, el sufrimiento forman parte de la condición histórica del hombre: Es una realidad existencial. Su misterioso por qué ha sido y es uno de los interrogantes más angustiosos del pensamiento humano ${ }^{190}$. La antigüedad pagana lo consideró efecto de la ignorancia [= Pitagóricos, Aristóteles] o una realidad dualísticamente opuesta al bien [= Platón, Estoa, Religiones orientales] y, como éste, eterna ${ }^{191}$. Diversa es la respuesta de la revelación bíblica, según la cual todos los seres creados por «el Dios bueno» son «muy buenos» ${ }^{192}$, entrando en el mundo a consecuencia del pecado y como castigo divino por éste el mal o esa fuerza positiva, que aflige y esclaviza al hombre, envenena las relaciones sociales y corrompe incluso el universo ${ }^{193}$, siendo aquél causado asimismo por «el maligno» diabólico ${ }^{194}$. Una respuesta prolongada por los Padres de la Iglesia, quienes, en contraposición al dualismo gnóstico y maniqueo, subrayan la bondad de Dios y de su creación, valorando el mal como efecto del pecado cometido por la «mala voluntad» del

Schnackenburg, Das Heilsgeschehen bei der Taufe nach dem Apostel Paulus, München 1950,4849.57-62.149-76; K. Kertelge, o.c., (supra, n. 175), 231-36.263-65; R. Tannehill, Dying and rising with Christ (BZNW 32), Berlin 1966; F. Mussner, Praesentia salutis, Düsseldorf 1967, 189-96 (más bibliografía, al respecto, en las notas siguientes). 188. $\operatorname{Rm~} 8,18 \mathrm{c}+$ Act 14,22 ; 1 Tes 3,3; $\operatorname{Rm} 8,35-36$; Jn 16,33, etc.

189. Mt 4,17par; 2Tim 1,8; Mt 5,10+1Pe 3,14; Mt 5,11+Fil 1,29; 2Tes 1,5. 190. Sobre la problemática del mal, Cf.: E. Masson, Le mal: DThC IX 1679-1704; W. Grundmann, Kakós: ThWNT III 470-82; T. Demand, Le mal et Dieu, Paris 1943; N.F.S. Ferré, Evil and christian faith, London 1946; A.D. Sertillanges, Le problème du mal, I-II, Paris 1948. 1951; L. Bouyer, Das Böse als christliches Problem: Documente 8.1 (1952) 20-53; J. Hellin, Dios y la razón del mal en el mundo: Pens 9 (1953) 5-27. 147-75; J. Nahert, Essai sur le mal, Paris 1955; B. Welte, Über das Böse. Eine thomistische Untersuchung, Freiburg 1959; E. Born, Le problème du mal, Paris 1960; K. Lüthi, Gott und das Böse, Zürich 1961; Ch. Journet, Le mal. Essai théologique, Fribourg 21962; O.A. Piper, Suffering and evil: IDB IV 450-53; J. Maritain, Dieu et la permission du mal, Paris 1963; H. Häfner (Hrsg.), Realität und Wirksamkeit des Bösen, Würzburg 1965; S. Portmann, Das Böse - Die Ohnmacht der Vernunft, Meinheim 1966; L. Jerphagnon, El mal y la existencia, Barcelona 1966; K. Hemmerle-J. Splet, El mal: SM IV 398-406 (bibliogr.); J. de Vaulx, Bien y mal: VTB 128-31; J. Bernhardt, Mal: CFT I 957-70 (bibliogr.). $\quad$ 191. Cf. E. Masson, a.c., 1681-88; W. Grundmann, a.c., 471-77; A.D. Sertillanges, o.c., I 19-152. 192. Mc 10,18par; Gén 3,31; Cf. Sal 33,5; Eclo 39,33.35; Sab 11,24; 1Tim 4,4. 193. Cf. Gén 3,16-19; 4,8-12.23-24; 8,5.11-13; Lev 26,14-39; Dt 28,15-46; Mc 7,21-23 (=Mt 15,19-20); Rm 1,28-32; 8,21-22; etc: W. Grundmann, a.c., 477s; O.A. Piper, a.c., 451; J. de Vaulx, a.c., 129s; S. Sabugal, $A b b a ́ \ldots, . ., 584 s . \quad$ 194. Cf. Mt 5,37; 13,19.38; Ef 6,16; 1Pe 5,8-9; 1Jn 5,18-19; Apoc 2,9-10. etc: O.A. Piper, a.c., 451. 
hombre a instigación del «maligno» ${ }^{195}$. Análoga valoración ofrece la revelación divina al por qué del sufrimiento. La moderna antropología científica y filosófica responden a este interrogante, afirmando que el dolor es natural efecto de la finitud existencial del ser humano, quien - como el animal- sufre por ser limitado: Es todo lo que la razón puede y debe afirmar. No es, sin embargo, la única ni última respuesta. Pues la razón del creyente, que busque en la revelación bíblica una respuesta a aquel interrogante ${ }^{196}$, se revela justamente ante esa presunta natural condición sufriente del hombre, creado por el Dios que «con sabiduría» y «por amor» hizo todas las cosas incluido el hombre y, por cierto, lo hizo todo «muy bueno» ${ }^{197}:$ ¿Es acaso el dolor efecto de su sabiduría y amor? ¿Está incluido aquél en la superbondad de la creación divina? Evidentemente, no. Y la fe nos lo asegura: ¡Dios no creó el dolor! ¡No es éste natural al hombre, creado «a imagen y semejanza» del Dios ${ }^{198}$ que no sufre y sí es feliz! ¡No es aquél condición natural de quien fue hecho por Dios «con el polvo de la tierra», pero seguidamente situado por Él en un estado de felicidad paradisíaca! ${ }^{199}$. Por eso, en vano se busca el vocablo «dolor» y sinónimos en los relatos genesíacos sobre la creación y situación paradisíaca del hombre (Gén 1,26-27; 2,7-17): ¡No existen! Aquél, sin embargo, aparece después de la "caída» o libre rebelión del hombre contra Dios y pérdida de su comunión con Él ${ }^{200}$ : Sólo entonces el ser humano comienza a «temer»y, por castigo de Dios, experimenta en lo más profundo de su feminidad y masculinidad la maldición divina de los «sufrimientos» y el «dolor», la «fatiga» y el «sudor» ${ }^{201}$, manifestando por tanto el dolor espiritual [ $=$ «miedo»] y corporal [ = «sufrimientos» y «fatiga»] el desequilibrio existencial del hombre, que

195. Así San Justino, 2Apol. 7,3; Taciano, Discurso, 11.19; Atenágoras, Legación, 24; San Ireneo, Adv. Haer., IV 37,1-6; Orígenes, Contra Celso, IV 40.62-66; San Agustín, De natura boni, 1.3.7.12-18; Conf., VII 7.11.18-22; De libero arbitrio, II 51-54; III 1-11.47-49; De civ. Dei, XII 6-8; Enchir., 11-15.23-24: Cf. E. Masson, a.c., 1689-96; A.D. Sertillanges, o.c., I 170-99; C.F. Bernhardt, a.c., 964-66. La filosofía escolástica y, en particular, Sto. Tomás prolonga sustancialmente esa respuesta agustiniana sobre el origen del mal (Cf. E. Masson, a.c., 1696-1703; A.D. Sertillanges, o.c., I 195-202), fundamentalmente condividida por los teólogos católicos modernos: Cf. A.D. Sertillanges, o.c., II 5ss; Ch. Journet, o.c., 27-199; y otros. 196. Cf.: A.S. Peake, The problem of the suffering in the OT, London 1904; J.Y. Batley, The problem of suffering in the OT, Oxford 1916; H. Schmidt, Gott und das Leid im AT, Münster 1926; W. Wichmann, Die Leidenstheologie (BWANT 53), Stuttgart 1930, 1-32; A.P. Shepherd, Sin, suffering and God, London 1931; E.S. Jones, Christ and human suffering, London 1933; W. Grundmann, a.c. 477-82; H.W. Robinson, The cross in the OT, London ${ }^{2} 1956$; P. van Imschoot, Théologie de l'AT, II, Tournai 1956, 303-14; E.F. Sutcliffe, Providence and suffering in the Old and New Testament, Edinburgh 1956, 39-158; O.A. Piper, a.c., 451-53; J. Giblet-P. Grelot, Enfermedad: VTB 276-79. Del todo instructivas son, a este respecto, las luminosas directrices ofrecidas recientemente por el Magisterio de la Iglesia: Juan Pablo II, Carta apost. SD (Ciudad del Vaticano 1984). 197. Sal 104, 24; 136,4-9; Sab 9,2; Gén 1,1-31 (supra, n. 192). Sobre la bondad de la creación, hecha por la sabiduría y el amor de Dios, Cf. supra, 246. 198. Gén 1,26-27: Cf. supra 246. 199. Gén 2,7-17: Cf. S. Sabugal, Abbá..., 582 (bibliogr.). 200. Gén 3,1-7: Cf. S. Sabugal, Abbá..., 582-83.703s. (bibliogr.). 201. Gén 3,10.16-19: Cf. S. Sabugal, Abbá..., 583 s (bibliogr.) 
orgullosamente rechazó su condición de creatura y dijo no a Dios, perdiendo por ello el don de su felicidad paradisíaca. La respuesta del divinamente inspirado y más antiguo teólogo - el Jahvista- de Israel al por qué del sufrimiento es, pues, clara: Entró en la historia humana como castigo divino por el pecado ${ }^{202}$, siendo por tanto aquél efecto del desequilibrio existencial introducido en el hombre separado de Dios. No es por tanto del todo incomprensible, que de algún modo comulguen en la maldición divina del dolor cuantos - «todos» los hombres- en aquel pecado participan (Cf. $R m 5,12)$ y a él añaden pecados personales. Aquel nexo entre pecado y sufrimiento es, por lo demás, concepción comúnmente atestiguada por casi todos los restantes teólogos veterotestamentarios ${ }^{203}$, siendo asimismo una opinión común del pensamiento judaico ${ }^{204} \mathrm{y}$ condividida, generalmente, por Jesús ${ }^{205}$ así como por los Autores neotestamentarios ${ }^{206}$. Una concepción no del todo extraña, por cierto, a la medicina científica, cuya psicoterapia muestra que determinadas enfermedades corporales pueden ser - de hecho lo son- consecuencia de un previo desequilibrio espiritual. Por lo demás, la revelación divina nos asegura también que, una vez introducido el sufrimiento en la historia humana, de aquél se sirve también Dios para probar la libre fidelidad del hombre a Él ${ }^{207}$, preanunciando por vez primera Isaías II la vicaria expiación de los sufrimientos [y muerte] del mesiánico Siervo de Dios «por las rebeliones» o «culpas» de su Pueblo y de «todos» ${ }^{208}$. Un preanuncio colmadamente cumplido en la vicaria expiación de la pasión y muerte de Jesús ${ }^{209}$ : Él realmente «llevó nuestros sufrimientos y soportó nuestros dolores», Él «fue herido por nuestras rebeldías y molido por nuestras culpas», siendo «entregado a la muerte por nuestras rebeliones» y ofreciendo «su vida en sacrificio por el pecado», entregán-

202. Así con: P. van Imschoot, o.c., 303; E.F. Sutcliffe, o.c., 46s; J. Giblet-P. Grelot, a.c., 276; S. Sabugal, Abbá..., 583. 203. Cf. Núm 12,1-10; 21,1-7; Dt 28,15.22-44; Jces 2,11-15; $3,7-8.12-14 ; 4,1-2 ; 6,1-6 ; 10,1-16 ; 13,1 ; 2 \operatorname{Sam} 24,10-15 ; 1 \operatorname{Re} 16,30-17,1 ; 21,25-29 ; 2 \operatorname{Re} 17,5-26$; $18,11-12 ; 21,10-15 ; 23,26-27 ; 24,1-4 ; 2$ Crón $12,5-9 ; 24,17-24 ; 26,16-20 ; 33,1-11 ; 36,14-21$; Eclo 38,15 ; Jer 6,$19 ; 11,10-11 ; 16,10-13 ; 26,4-6 ;$ Ez 4,1-11,12; 12,1-20; 20,7-33; 21,1-22; 22,1-23,49; Sab 11,15-17; 12,23-27; etc: Cf. W. Grundmann, a.c., 477s; P. van Imschoot, o.c., 303ss; E.F. Sutcliffe, o.c., 87-96; J. Giblet-P. Grelot, a.c., 276s. 204. Cf. S. Sabugal, Abbá..., 594s (bibliogr.). 205. Cf. Mc 2,1-12par (v. 5par); Lc 13,10-17 (v. 16); Jn 5,1-14 (v. 14); no siempre, sin embargo, condividió Jesús aquella concepción (Cf. Jn 9,2-3; 11,4; Lc 13,1-3). A este respecto, Cf.: J. Giblet-P. Grelot, a.c., 277; S. Sabugal, Abbá..., 601s. 206. Además de los citados textos evangélicos (supra, n. 205), Cf. Lc 1,6.20; Act 12,22-23; 13,8-11; 1Cor 11,29-30. 207. Paradigmáticas, a este respecto, fueron las «pruebas» sufridas por Abraham (Gén 12,1-9; 22,1-19) y los demás Patriarcas (Cf. Jdt 8,25-27), por el pueblo de Israel (Cf. Dt 8,2-3; Jces 2,21-22; 3,1-4; Sab 11,9 etc.) y sus justos, especialmente Tobias y Job (Cf. W. Wichmann, o.c., 6; E.F. Sutcliffe, o.c., 110-19; S. Sabugal, $A b b a ́$..., 695-703: bibliogr.), así como por los fieles de las primeras Comunidades cristianas: Cf. S. Sabugal, Abbá..., 711-16. 208. Is 53,1-12: Cf. S. Sabugal, Abbá..., 624s (bibliogr.). 209. Así lo previó y preanunció Jesús (Cf. suprà, 500s, reflejándolo claramente los relatos evangélicos de su pasión (Cf. supra, 500-9), interpretación común de los Evangelistas (Cf. supra, 510-13) y demás teólogos neotestamentarios (Cf. supra, 515s, nn. 127131), recientemente subrayada con energía por Juan Pablo II, o.c. (supra, n. 196), nos 17-19. 
dose «indefenso a la muerte» y llevando «el pecado de todos» para «justificar a todos», antes de ser por Dios «exaltado y glorificado» al resucitarle «de entre los muertos» como «Espíritu vivificante» y constituirle único «Señor y Mesías» ${ }^{210}$. En Cristo sufriente, muerto y resucitado «se ilumina el enigma del dolor..., que fuera del Evangelio nos envuelve en absoluta oscuridad» ${ }^{211}$, pues el sufrimiento corporal y espiritual del hombre fue asumido, redimido y transformado por Quien «se hizo maldición en favor nuestro» (Gál 3,13) y así cambió la prístina maldición divina del sufrimiento (Gén 3,16-19) en bendición: Ése fue no sólo redimido por la expiación vicaria de su pasión y muerte, sino también convertido en medio redentor así como en camino de glorificación.

b) De esa cualidad redentora y glorificadora participa también el dolor cristiano o de los incorporados a Quien, por lo demás, con su pasión «nos dejó ejemplo para seguir sus huellas» ${ }^{212}$. El sufrimiento corporal y espiritual del cristiano fiel a su bautismal incorporación a Cristo, y por ello partícipe de su redención y glorificación, no es ya maldición divina por el pecado sino sufrimiento redimido por la vicaria pasión expiatoria del Hijo de Dios, quien asumió el dolor humano para sufrirlo «en vez del hombre y por el hombre» ${ }^{213}$ pecador, no sin transformarlo y dignificarlo con el amor que lo sufrió: ¡Por «amor» a cada hombre «se entregó» Cristo a su pasión! (Gál 2,20). El sufrimiento de los a Él bautismalmente asociados es, pues, un dolor redimido y dignificado: Amado de Dios. Se comprende así la otra característica del dolor cristiano: Es un don divino, pues a los fieles «fue concedida [ipor Dios!] la gracia (sic!) no sólo de creer en Cristo, sino también de sufrir por Él» ${ }^{214}$. Lo que originalmente fue castigo y maldición divina para Adán y cuantos en su pecado participan (Cf. supra), devino ahora don y bendición para el «nuevo Adán» y cuantos en su redentora pasión comulgan. El dolor cristiano, en efecto, es esencialmente «comunión en los sufrimientos de Cristo» mismo, «con quien sufrimos» ${ }^{215}$. No sufre, pues, sólo el creyente en Cristo, sino unido a Quien «le amó» y, «por cuyo amor» fortificado, no duda «salir victorioso en toda clase de tribulación y dolor» ${ }^{216}$. Aceptados éstos, por lo demás, en la corredentora misión de «completar en su carne lo que falta a las tribulaciones de Cristo, en favor de su Cuerpo la Iglesia» ${ }^{217}$ : Los sufrimientos de los miembros completan los sufridos por la Cabeza, y a éstos se aúnan en la consumada redención del Cuerpo eclesial. Ese valor corredentor del sufrimiento cristiano

210. Is 53,5-12+52,13; Act 3,13-15; 1 Cor 15,45; Act 2,36. 211. Conc. Vat. II, Const. GS 22. 212. $1 \mathrm{Pe} 2,21-23$. Para su análisis, Cf.: M.-E. Boismard, Quatre hymnes baptismales..., 111-19; A. Sisti, Sulle orme di Cristo sofferente: BibOr 10 (1968) 59-68; K.H. Schelkle, Die Petrusbriefe (HerdersThKNT XIII.2), Freiburg ${ }^{4} 1976,81-86.112$ s. 213. Juan Pablo II, o.c., n. ${ }^{\circ}$ 19. 214. Fil 1,29; Cf. Act 5,41 . 215. Fil 3,10; 1 Cor 1,$5 ; \mathrm{Rm} 8,17$ : «Los cristianos llevan con Cristo sus sufrimientos de muerte» (H. Urs von Balthasar, e.c., [MS, III. 2], 233). 216. Rm 8,35-37; Cf. 2Cor 12,7-10; 4,7-12. 217. Col 1,24. Para su análisis, Ćf. J. Kremer, Was an den Leiden Christi noch mangelt (BBB 12), Bonn 1956; J. Gnilka, Der Kolosserbrief (HerdersThKNT X. 1), Freiburg 1980, 94-98 (bibliogr.). 
hace precisamente, que el discípulo del Redentor incluso «se alegre por» aquél y «sobreabunde de gozo en las tribulaciones» sufridas por Cristo, considerándolas «un gan gozo» en fidelidad al makarismo y exhortación del Maestro: «...;Alegraos y regocijaos!» ${ }^{218}$. Pues sabe además que, como «era necesario que Cristo padeciera y así entrara en su gloria» ${ }^{219}$, también sus propios sufrimientos son garantía segura o senda de glorificación: A las injurias y persecuciones sufridas «por causa de» Cristo les está reservada por el Padre «la gran recompensa» del «Reino de los cielos» o «un pesado caudal de gloria eterna», pues «sufrimos con Él para ser también por Él glorificados» ${ }^{220}$. La gloria de la resurrección fue, es y será meta final de la «vía dolorosa». La cual, por lo demás, conduce a la cruz:

\section{2) «Crucificados con Cristo»}

a) La bautismal y existencial asociación del cristiano a los sufrimientos de Cristo incluye la participación en su cruz: Haber sido y estar con Él crucificados ${ }^{221}$. Ya en el bautismo, en efecto, «nuestro hombre viejo fue crucificado con» Cristo o eliminada la esclavitud "del pecado», al ser clavadas — digámoslo así- las «malas pasiones» o las tres «concupiscencias» con los clavos de la triple renuncia y confesión bautismal ${ }^{222}$. Pero aquella concrucifixión bautismal fue sólo un comienzo: El inicio de una existencia crucificada o permanentemente desligada del pecado y clavada con el amor del Crucificado. Viviendo «según el Espíritu» de Jesús, en efecto, «los que son de Cristo [= cristianos] crucificaron de una vez para siempre la carne con sus malas pasiones y perversos deseos», de modo que «con Cristo han sido y están crucificados» ${ }^{223}$. Lo que significa: La cruz caracteriza esencialmente a la existencia del discípulo, que realmente sigue al Maestro. Así lo aseguró ya Jesús y lo subrayan los evangelistas: Tras haber sido confesado Aquél como «el Mesías»o único Salvador por «sus discípulos» en boca de «Pedro», Jesús les predijo por vez primera su pasión, muerte y resurrección, condicionando luego «a la multidud junto con sus discípulos» el seguirle al «autonegarse» y «llevar la propia cruz [cada día: Lc], pues -añadió- quien quiera salvar su vida la perderá, pero la salvará quien por mí [y el evangelio: Mc] la pierda» ${ }^{224}$. ¿Qué significa

218. Col 1,24; 2 Cor 7,4; Sant 1,2; Mt 5,11-12. Los santos entendieron muy bien esta alegría del sufrimiento cristiano, pudiendo afirmar uno de ellos «haber llegado a un punto en que ya no puedo sufrir, porque me es dulce todo padecimiento»: Sta. Teresita del Niño Jesús, Obras completas, Burgos ${ }^{3} 1969,385$. 219. Lc 24,26; Cf. 24,46; Act 17,3; Mc 8,31par. 220. Mt 5,1012; 2 Cor 4,17; $\operatorname{Rm} 8,17-18$. 221. $\operatorname{Rm~} 6,6$; Gál 2,19; 5,24. A este respecto, además de la bibliografía citada (supra, n. 187), Cf.: J. Leal, «Christo crucifixix sum cruci» (Gal 2,19): VD 19 (1939) 76-80.98-105; R. Tannehill, o.c., 21-29.55-62; F.J. Ortkemper, Das Kreuz in der Verkündigung des Apostels Paulus (SBS 24), Stuttgart ${ }^{2} 1968,81-87$; H. Urs von Balthasar, e.c., 231-33; J. Schneider, Stauróo: ThWNT VII 581-84: 583; F. Mussner, Der Galaterbrief (HerdersThKNT IX), Freiburg 1974, 180s; E. Brandenburger, Cruz: DTNT I 358-68: $366 . \quad 222$. Rm 6,6; Gál 5,24; (f. 1 Jn 2,16. 223. Gál 5,24-25; 2,19. 224. Mc 8,29.34-35par; Cf. Lc 14,27 (=Mt 10,38); 23,26 . 
«llevar la propia cruz»? El mencionado contexto inmediato así como la interpretación de la «cruz» por el evangelista Lucas. [ = «la cruz diaria»] no deja lugar a dudas: Quien quiera seguir a Jesús, confesándole como el único Salvador de la propia historia, debe ante todo «autonegarse» o renunciar a confesarse salvador de la propia vida, _i «la perderá»!-, para confesar en verdad que sólo Jesús lo es; una renuncia o autonegación prácticamente demostrada en la positiva «aceptación de la propia cruz» o de cuanto «cada día» nos hace sufrir y nos destruye, - ieso es «la cruz diaria»!-, convencidos que de todo eso únicamente el mesiánico Salvador puede salvar ${ }^{225}$. iSólo quienes, en diarias situaciones de cruz, se autorreniegan ser salvadores y la abrazan, confesando así al Salvador, son sus verdaderos seguidores! ¡Le siguen realmente sólo quienes «diariamente» llevan la propia cruz y, unidos a Jesús o «fijos los ojos en» Quien la «soportó sin miedo a la ignominia», peregrinan por este mundo hacia la futura «ciudad» de Dios, «cargando con su oprobio»! ${ }^{226}$ : El oprobio de creer que «todo lo hecho por Dios es bueno» y que cuanto nos suceda no escapa de su providencia y amor, pues «en todas las cosas interviene Dios para el bien de los que le aman» ${ }^{227}$; el oprobio del Sermón de la Montaña, que nos exige «no resistir al malvado» y sí «amar a nuestros enemigos», venciendo «al mal con el bien» ${ }^{228}$; pues ése fue principalmente el oprobio sufrido por el mesiánico Siervo de Dios, Cristo, quien «al ser insultado no respondía con insultos» y, «al padecer, no amenzaba sino se ponía en manos de Quien juzga con justicia», dejándonos así «ejemplo para seguir sus huellas» ${ }^{229}$. ¡Sólo quienes éstas siguen, con el espíritu del Siervo de Jahveh y

225. De otro modo: R. Koolmeister, Selbstverleugnung, Kreuzaufnahme und Nachfolge. Eine historische Studie über Mt 16,24: "Charisteria I. Kopp», Stockolm 1954, 64-94; D.R. Flechter, Condemned to die. The logion on Cross-bearing: What does it mean?: Interpr 18 (1964) 156-64; E. Dinkler, Signum crucis, Tübingen 1967, 77-98; J.G. Griffiths, The disciples's cross: NTSt 16 (1969-70) 358-64: 360ss; J. Schneider, Staurós: ThWNT VII 577-79; R. Pesch, Markus, II 59s; E. Brandenburger, a.c., 368. Más afín a nuestra interpretación es la ofrecida por J. Jeremias, Theologie NT, 232 (trad.españ., 281s). Esa sentencia de Jesús, sin paralelo en la literatura judaica (Cf. Str.-Bill., I 587) ni en la específica literatura cristiana del NT, pero de clara resonancia semitica (Cf. M. Black, An aramaic approach to the Gospels and Acts. Oxford ${ }^{3} 1967,195 \mathrm{~s}$; K. Beyer, Semitische Syntax im NT, Göttingen ${ }^{2} 1968$, 227s) y en sintonía con «el imperiosamente exigente lenguaje de Jesús», especialmente con su «imperiosa llamada al seguimiento» (H. Schürmann, Die Sprache des Christus: BZ 2 [1958] 54-84: 80s), tiene toda garantía de autenticidad (Así con R. Pesch, o.c., I 61). Instructivas sobre la interpretación de ese «logion» (cuya historia delinea imperfectamente R. Koolmeister: Cf. supra) son las reflexiones de K. Rahner, Selbstverwirklichung und Aufnahme des Kreuzes: StTh VIII, Einsiedeln 1967, 322-26; Id., Nachfolge des Gekreusiglen: Ib., XIII, Einsiedcln 1978, 188-2013: Cf. también K. Barth, Dogmatik, IV. 2. \%urich -1964, 676-94. 226. Hebr 12,1-2; 13,13-14. 227. 1 Tim 4,4; Rm 8,28, 228. Mt 5,38-48 (=Lc 6,29-36); Rm 12,14-21: Cf. S. Sabugal, Abba..., 675-90 (bibliogr.). 229. 1Pe 2,21-24: Sobre este texto, Cf. la bibliografía citada (supra, n. 212). 
por el sendero de la propia cruz, son verdaderos discípulos del Crucificado! Pues han entendido que:

«Vivir de amor no es plantar el peregrino

de la vida su tienda en la cima del Tabor, es subir con Jesús hacia el Calvario y

valorar la cruz como precioso don» ${ }^{230}$.

Es, pues, transcendental para el cristiano individuar y conocer bien cuál es la propia cruz - ¡no las cruces! - «de cada día», para medir con acierto su cualidad cristiana en el diario seguimiento del Crucificado, en la propia actitud frente a la cruz: ¡El termómetro de la existencia cristiana es la cruz! En la personal postura frente a ella se discierne efectivamente no sólo quién es verdadero discípulo de Cristo, sino también la talla misma de la existencia cristiana, cuya espiritualidad y «ética es cruciforme» ${ }^{231}$. Y aquella postura o reacción puede ser cuádruple ${ }^{232}$.

-De rechazo, por considerarla gnóstica o maniqueicamente un mal que debe ser combatido con todos los medios posibles, perteneciendo éstos en realidad al número de quienes «se avergüenzan del Evangelio» $(\mathrm{Rm} 1,16)$, por considerar «la cruz de Cristo» insoportable «escándalo» o «locura» total (1Cor 1,23): ;No son discípulos del Crucificado!

-De soslayo o hipócrita rechazo, actitud propia de los cobardes que pretenden vivir en el constante compromiso de ser fecundo «grano de trigo» sin dejarse cubrir por «la tierra» de la prueba ni - menos aún- morir en «el surco» de la misma (Cf. Jn 12,24), de querer «salvar la propia vida» sin «odiarla en este mundo» ni -menos aún- «perderla por causa de Jesús», de ser sus testigos «en el mundo» y a la vez «ser del mundo» (Cf. Jn 17,11.14), de «poseer el pensamiento de Cristo» (1Cor 2,16) y a la vez "conformarse a la mentalidad de este mundo» (Cf. Rm 12,2): ¡No son discípulos del Crucificado!

-De tolerancia o pasiva y estoica resignación ante la prueba, como necesario medio de superar su pésimo influjo y dominarla, acudiendo [si es preciso] para ello a la intercesión de los santos y evocando - icómo no! - el ejemplo del Crucificado: ¡No son discípulos suyos!

-De aceptación positiva y animada por la fe en la victoria del Crucificado sobre toda realidad de cruz, abrazando por ello «la cruz de cada día» y demostrando así «gloriarse en la cruz de nuestro Señor Jesucristo» (Gál 6,14), convencido de que el Señor resucitado hará gloriosa esa cruz diaria como el Padre glorificó la suya: ;Sólo éstos son adultos discípulos del Crucificado!

$\mathrm{Y}$ es que sólo en aceptadas situaciones de prueba o de cruz es posible encontrar al Resucitado: En la "vía dolorosa» de la prueba o en eventos de cruz

230. Sta. Teresita del Niño Jesús, o.c., 959. 231. H. Urs von Balthasar, Neun Sätze zur kristlichen Ethik: «Prinzipien christlicher Moral» (Hrsg. J. Ratzinger), Einsiedeln ${ }^{2}$ 1975, 67-93: 77. 232. Cf. S. Sabugal, $A b b a ́ . . ., 713$ s; sobre la «prueba» o cruz del cristiano, Cf. $I b .$, 711-16. 
le encontraron efectivamente los grandes convertidos y le «experimentaron» los santos, quienes por ello la abrazaron con amor y fielntente la llevaron «cada día»; convencidos, por lo demás, que:

«En la cruz está la vida

y el consuelo,

y ella sola es el camino

para el cielo.

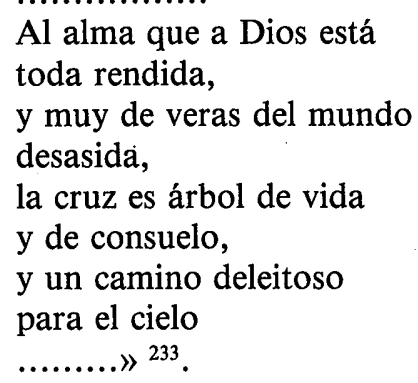

¡Por la cruz a la gloria! Esa fue la vía de Cristo. Y ésa es también la única senda del verdadero cristiano, invitado por ello a interrogarse: ¿Cuál es hoy mi cruz y mi actitud o postura frente a ella? Esta pregunta debería formularse con sinceridad y frecuencia todo discípulo de Cristo.

b) Análogo interrogante, por tanto, deberían plantearse también no sólo el pastor y el catequista, - para determinar el puesto que «la palabra de la Cruz» (1Cor 1,18) ocupa en su acción pastoral y en su instrucción catequética-, sino también el exegeta y el teólogo, siempre invitados a examinar su específico carisma eclesial y a valorar tanto la cualidad como la talla de su ministerio docente frente a la teología de la cruz o estaurología cristiana ${ }^{234}$. Pues ésta constituye un capítulo central de la teología neotestamentaria. «La Cruz» de Cristo, en èfecto, compendia toda la obra redentora de Jesús, cuya «historia es en último término historia de la pasión», siendo su «resurrección la resurrección del Crucificado» ${ }^{235}$. Así lo entendió ya un antiguo himno cristiano, al interpretar toda la existencia de Cristo a la luz de la humillación y exaltaçión del Siervo sufriente de Dios: Como una gradual «kénosis» o des-

233. Sta. Teresa de Jesús, Obras completas, II, Madrid 1954, 961 234. A este respecto, además de los artículos generales sobre «la Cruz» (J. Blinzler, LThK VI 607s; J. Audusseau-X. Léon-Dúfour, VTB 202s; J. Schneider, ThWNT VII 575-77; E. Brandenburger, DTNT I 363-67), Cf.: L. Cerfaux, Le Christ..., 120-24; F.J. Ortkemper, o.c., 9-64.88ss; AA.VV., Das Kreuz Christi als Grund des Heils, Gütersloh ${ }^{3} 1969$; E. Brandenburger, «Staurós». Kreuzigung Jesu und Kreuzestheologie: WuD 10 (1969) 17-43: 35ss; J. Ratzinger, Einführung..., 230-42 (trad. españ., 244-56); G. Klein, «Ärgernisse», München 1970, 115-31; H.-H. Kuhn, Jesus als Gekreuzigter in der frühchristlichen Verkündigung bis zur Mitte des 2.Jahrhunderts: ZThK 72 (1975) 1-46: 26-41; J. Moltmann, Der gekreuzigte Gott, München ${ }^{4} 1981,34-77.105-267 . \quad 235$. K. Barth, o.c., IV. 2, 336.376; Cf. supra, 498. 
censo en la servicial autohumillación, que tocó su fondo en «la muerte de cruz»y, «por eso, Dios lo exaltó» como «Señor» ${ }^{236}$ : Por la cruz a la exaltación. Análogo mensaje ofrece el evangelista Juan: La cruz fue el trono regio del Jesús exaltado y glorificado, por devenir en ella no sólo fuente de «vida eterna» y salvación para los en Él creyentes, así como epifánico centelleo del amor de Dios al «mundo» pecador, que por ello condena a su diabólico «príncipe» y «atrae a todos a él», sino también el lugar sagrado desde donde nos legó por Madre a su Madre y de donde - por su costado abierto- nació la Iglesia ${ }^{237}$. El máximo predicador y teólogo de la cruz, sin embargo, es Pablo, quien con la expresión «la cruz de Cristo» o «Cristo crucificado» ${ }^{238}$ sintetizó todo el evento salvífico —redención gratuita mediante la muerte y resurrección de Jesús- por él predicado ${ }^{239}$, siendo aquellas fórmulas como el ideograma de la soteriología paulina. Pues su predicación de «Cristo crucificado» a los Gálatas equivale al anuncio de la justificación del pecador «no por las obras de la Ley sino por la fe en Jesucristo» crucificado ${ }^{240}$, como «la palabra de la cruz o el anuncio de «Cristo crucificado» a los Corintios traduce su kérygma - «iesto predicamos!»- sobre la mesiánica muerte expiatoria y resurrección gloriosa del Siervo de Dios «Cristo» ${ }^{241}$, mediante cuya expiatoria crucifixión quiso Dios «cancelar» gratuitamente los pecados del hombre y «reconciliarlo» con Él ${ }^{242}$. Así fulguró salvíficamente «la sabiduría de Dios» en la crucifixión de Cristo: Muerte ignominiosa y, por tanto, «locura para los paganos» ${ }^{243}$. También en «la debilidad» de la cruz se reveló salvíficamente «la fuerza de Dios» que, con el gratuito don de la justificación «mediante la fe en Cristo crucificado y sin las obras de la Ley» mosaica, excluyó toda cooperación humana y todo motivo de autogloriación, deviniendo por ello «Cristo crucificado escándalo para los judíos» ${ }^{244}$ así como para todos los pelagianos antiguos y modernos, que confían en sus obras y alimentan una piedad autosuficiente. Que Dios haya manifestado su amor al mundo pecador y lo haya redimido mediante la ignominiosa muerte de su Hijo, - devenido hombre y hecho siervo, para morir finalmente como un criminal-, no podía menos de

236. Fil 2,6-11 (= Is 52,13-53,12): Cf. supra, 516, n. 131 (bibliogr.) 237. Jn 3,14-17; 12.28-32; 19,25-27.34: Cf. supra, 513-15. 238. 1Cor 1,17-18.23;2,2; Gál 3,1; 5,11; 6,12; Fil 3.18 239. Cf. 1 Cor 1,$23 ; 15,3-11$; Ef $2,1-18$, etc. 240. Gál 2,16.21; 3,1-2. 241. 1Cor 1.18.23; 15,3-8.11. 242. Col 2,14; 1,20; Ef 2,14-16. 243. 1Cor 1,18.23. Por ser la crucifixión una muerte ignominiosa (Cf. supra, 505), los creyentes en el Crucificado eran considerados por los paganos contagiados de «locura» (amentia: Plinio el Joven, Ep. X 96,4-8) o miembros de «una superstición vana y demente» (demens: Minucio Félix, Octavio, IX 2): Cf. M. Hengel, Crucifixión, 13-23. Pero ya 400 años a.C. describió el pagano y máximo pensador griego «al hombre justo», como quien «va inmutable hacia la muerte con la inmerecida fama de hombre injusto» y, tras ser «fustigado, torturado» así como haber «sufrido toda clase de males, será crucificado...» (Platón, República, II 361 e-362a: Cf. E. Benz, Der Gekreuzigte bei Plato, im NT und in der alten Kirche [Abh. Mainzer Akademie, 12], Mainz 1950), mostrando así aquel pagano que en el dejarse crucificar se revela la justicia del hombre justo: Cf. J. Ratzinger, o.c., 240s (trad. españ., 254s). 244. 1Cor 1,23.30-31; Rm 3,27; Cf. Gál 2,16. 
sonar a «locura» para oídos paganos y «escándalo» para oídos judaicos, pues esa «sabiduría» y «fuerza de Dios» manifestada en la Cruz es misterio insondable, sólo por la fe inteligible y sin duda amable. La Cruz, en efecto, «es el misterio más profundo del cristianismo» ${ }^{245}$. También fue y debe ser, por tanto, el nervio central de la evangelización y catequesis, de la pastoral y teología cristiana, cuyos ministros - evangelizadores y catequistas, pastores, teólogos y exegetas - jamás deben soslayar su «escándalo» y «locura» ni limar o acaramelar su mensaje, «con el fin de evitar la persecución por la cruz de Cristo» o para ganar a «los que viven... como enemigos» de ella y atraerse su aplauso, al precio de «acomodarse a la mentalidad de este mundo» ${ }^{246}$. Aquéllos, por el contrario, deben delimitar valientemente la radical contraposición entre la violencia y la misericordia, la lucha de clases y el amor al enemigo, el mensaje del «Capital» y del «Sermón de la Montaña», el mesías revolucionario y el Siervo de Jahveh, Barrabás y Jesús: ;Ante esa alternativa nos sitúa la Cruz! Pues ella fue y es «el signo de la cristiandad» ${ }^{247}$ y la bandera de la Iglesia, cuyas comunidades no pueden ser edificadas sobre «otro cimiento que el de Jesucristo» crucificado (1Cor 2,11). De ahí que por el puesto asignado y la importancia dada a la cruz de Cristo se puede valorar con acierto la solidez de toda acción pastoral, la envergadura de toda instrucción catequética, la talla de toda reflexión teológica, la medida de toda santidad cristiana: Los grandes pastores y catequistas de la Iglesia, sus grandes teólogos y santos fueron sin excepción amantes de la cruz y del Crucificado. Así lo atestigua su cálido y místico elogio por un anónimo cristiano antiguo:

- «iÁrbol de salud eterna, del que me nutro y deleito, en cuyas raíces me enraizo y en cuyas ramas me extiendo!

Alcé a su sombra mi tienda, y en ella refugio fresco encontré, al amparo del sofocante calor y viento.

- Son sus hojas mi follaje, y mis delicias sus frutos, con los que - mi reserva eterna- me regocijo y me nutro; pues ella mi hambre sacia y mi sed con su agua apaga, ¡cubre ella mi desnudez con las hojas de su Espíritu!

-En el temor a Dios me protege y en el tropiezo es mi apoyo, es mi precio en el combate y, en el triunfo, mi trofeo; ella es mi camino angosto $\mathrm{y}$, también, mi estrecha senda, ¡ es la escala de Jacob, en cuya cima el Señor se sienta!

-Ella es el árbol celeste, que se alza de la tierra al cielo, sostén de todas las cosas y apoyo del universo; es de la tierra el soporte y del mundo la juntura, su Espíritu enlaza a los hombres, que por Él en Dios se aúnan!

- La cumbre de los cielos toca la señera cruz con su cima,

245. R. Guardini, El Señor, I, Madrid ${ }^{5} 1963,519$. 246. Gál 6,12; Rm 12,2. 247. E. Brunner, Dogmatik, II, Zürich 1960, 351. 
y con sus pies la tierra sólidamente reafirma; ipues con sus inmensos brazos, que amar y ser amado gritan, estrecha en la cruz el Señor cuanto en cielo y tierra exista! ${ }^{248}$.

Este inspirado panegírico a la cruz del Señor es condividido sin ambages por cuantos en ella «se glorían», por haber sido instruidos con «la sabiduría de Dios» revelada en «la locura» de la cruz, fortalecidos con «la fuerza de Dios» desplegada «en la debilidad» de la misma, por haber experimentado sobre todo el amor gratuito de Dios manifestado en la ignominiosa muerte de su Hijo, con quien por ello «están crucificados» y, más aún, participan de su muerte:

\section{3) «Muertos con Cristo»}

La bautismal y existencial asociación del cristiano a los sufrimientos y crucifixión de Cristo culmina en la configuración con su muerte, en la que anhelan participar "comunicando en sus padecimientos» ${ }^{249}$.

3.1) Una configuración ya inaugurada mediante los sacramentos del Bautismo y de la Eucaristía. Pues como la total inmersión en el agua simboliza la muerte ${ }^{250}$, quienes en las aguas bautismales fueron sumergidos o «bautizados para unirse a Cristo», han sido por ello «bautizados para asociarse a su muerte» o unirse sacramentalmente a Él «por una muerte semejante a la suya», habiendo por tanto aquéllos «muerto con Cristo» al pecado, ya que como «su muerte fue un morir al pecado para siempre» y ahora «vive para Dios», también los bautismalmente asociados a su muerte deben «considerarse muertos al pecado y - unidos a Cristo Jesús- vivos para Dios» ${ }^{251}$. La bautismal configuración a la muerte de Cristo realizó, pues, en los bautizados una «muerte» a lo que - el pecado- en Adán y en todo pecador «mató» y «mata» la comunión con Dios, pues «el salario del pecado es la muerte» ${ }^{252}$. Por el bautismo, por tanto, aquéllos «han muerto»y, más exactamente, «han muerto con Cristo» ${ }^{253}$ a toda realidad de pecado, siendo con ello «liberados» de la radical esclavitud y tiranía impuesta por aquél así como por el «temor a la muerte» cau-

248. Anónimo, Homélies Pascales (SC 27), Paris 1950, 176-79 (Hemos retocado ligeramente el texto - ¡no su contenido!-, para versificar en lengua hispana su ciertamente poética prosa griega). 249. Fil 3,10. A este respecto, además de la bibliografía citada (supra, n. 187), Cf.: P. Bonnard, Mourir et vivre avec Jésus-Christ d'après saint Paul: RHPhR 36 (1956) 101-112; A. Feuillet, Mort du Christ et mort du chrétien d'après les épîtres pauliniennes: RB 66 (1959) 481 513. 250. Gén 6,17; 7,17-23; Éx 14,27-29, etc: Cf. M.-E. Boismard, Agua: VTB 52-56: 53s; J. de Fraine-P. Grelot, Mar: Ib., 507s. 251. Rm 6,1-11. Para su análisis, además de la bibliografía citada (supra, n. 187), Cf.: R. Tannehill, o.c., 21-39; H. Frankemölle, Das Taufverständnis des Paulus. Taufe, Tod und Auferstehung nach Röm 6 (SBS 47), Stuttgart 1970, 31-107; R. Schnackenburg, Todes -und Lebensgemeinschaft mit Christus. Neue Studien zu Röm 6, 1-11: "Schriften zum NT», München 1971, 361-91 (bibliogr.); B.N. Baye, «Baptizein eis» with special reference to $R m$ 6: StEv 6 (1973) 281-86; H. Schlier, Der Römerbrief (HerdersThKNT VI), Freiburg 1977, 190-201. 252. Rm 6,23a; Cf. 5,12.21; Gál 6,8a; 1Tim 5,6; Sant 1,15; Lc 9,60 (=Mt 8,22); 15,24.32; Prov 8,36; Sab 1,16. A este respecto, Cf. S. Sabugal, Abbá..., 603-4.653. 253. Rm 6,8; Col 3,2; 2 Tim 2,11. 
sado por él ${ }^{254}$. Esa muerte bautismal, por lo demás, se prolonga en la eucarística participación al «memorial» de la muerte de Cristo, que los fieles sacramentalmente «anuncian» y actualizán «cada vez que comen el Pan» del Cuerpo del Señor y «beben el cáliz» de su Sangre, entregado aquél como «sacrificio expiatorio» y derramada ésta «para el perdón de los pecados» ${ }^{255}$ : ¡En la «cotidiana fracción del Pan» eucarístico (Act 2,42.46) sellan aquéllos su bautismalmente iniciada «muerte con Cristo» al pecado! Ya no tiene, pues, éste poder sobre quienes, en su vida, permanecen fieles a esa muerte bautismal y eucarística, viviendo en el mundo como signos personales de «muerte al pecado» y «vida para Dios», como cadáveres frente a la seducción del pecado: No se deleitan en su fruto prohibido, ni aceptan la seductora caricia de sus concupiscencias, ni reaccionan ante su «aguijón»; pues «se consideran muertos al pecado» para siempre o como quienes «han muerto» y tienen «escondida con Cristo en Dios su vida»: ¡Esa «vida nuevai», que ahora ofrecen «a Dios como vivos [retornados] de entre los muertos» y anclados en la segura esperanza de «vivir con» Cristo o participar de su gloria, «cuando Él se manifieste»! ${ }^{256}$.

3.2) Como prolongación de la «muerte» y «vida nueva» con Cristo o inaugurada en el Bautismo y en la Eucaristía, la existencia del cristiano se caracteriza esencialmente por ser una vida mortal y muerte vital: Vive «muriendo» $y$, en esta muerte, no sólo experimenta la «nueva vida» sino también la comunica o trasmite a los aún «muertos» por el pecado.

a) Como la de Jesús, en efecto, también la existencia del cristiano está regulada por un misterioso pero real designio divino, _ ja la resurrección por la muerte!-, que la misma naturaleza ilustra: Sólo tras la muerte otoñal e invernal llegan las plantas a la floración primaveral y a la fructificación estival; só-

254. Rm 6,12-22; Hebr 2,14-15. 255. 1Cor 11,23-26; Mt 26,26-28par: Cf. supra, 502. 256. $\mathrm{Rm} 6,11 ; \mathrm{Col} 3,3 ; \mathrm{Rm} 6,4.13$; Col 3,4. Estos análisis prececentes muestran claramente, que la existencia del cristiano o seguidor de Cristo sufriente y Mártir del Padre está marcada profundamente por el sello de una espiritualidad martirial, diariamente sostenida y fortificada por la eucarística participación del Cuerpo y Sangre del Señor: Decimos «amén» al Cuerpo partido de Cristo y lo comemos, para poder luego dejarnos partir por los demás; decimos «amén» a la Sangre derramada [ = Vida] de Cristo y la bebemos, para poder luego dar la vida por Cristo en favor de todos. Esa comunión con la muerte o martirio de Cristo rearma, pues, al cristiano para ser el confesor de su amor a los pecadores y llevar «cada día su propia cruz» $(\operatorname{Lc} 9,23)$, actuando así ya ese «martirio incruento» (Cf. San Cipriano, A Fortunato, 13; De los celos y la envidia, 16; Orígenes, In Num. Hom., X 2), cuya fiel vivencia es la mejor preparación para el eventual martirio cruento o divino «don eximio» de asemejarse plenamente con Cristo mediante «la efusión de la propia sangre» y el «supremo testimonio de amor ante todos» (Conc. Vat. II, Const. LG V42). Esa espiritualidad martirial caracterizó efectivamente la vida cristiana de los primeros siglos (Cf. K. Baus, Manual de Historia de la Iglesia [dir. H. Jedin], I Barcelona 1966, 429-32) así como -y por ello- la espiritualidad de las antiguas vírgenes cristianas y, en general, del monacato primitivo: Cf. F. de Vizmanos, Las vírgenes cristianas de la Iglesia primitiva, Madrid 1949, 225-27; G.M. Colombás, El monacato primitivo, II, Madrid 1975, 172-74. Sobre la teología y espiritualidad del martirio, Cf. O. Semmelroth, Martirio: SM IV 455-60 (bibliogr.); Th. Baumeister, Die Anfänge der Theologia des Martyriums (MüBTh 45), Münster 1980, 66-306. 
lo - - ejemplificó Jesús - si «el grano de trigo cae en tierra y... muere, da mucho fruto»; y explicó seguidamente a sus discípulos el significado de esta semejanza: ; «Pierde su vida quien la ama» o desea él sólo salvarla, «pero la conserva para la vida eterna quien la odia en este mundo» por Él, y con Él: la pierda! ${ }^{257}$. Esta experiencia de muerte para la vida sella profundamente la existencia de los discípulos de Cristo, convencidos de que «llevamos siempre y por doquier en nuestro cuerpo el morir de Jesús, a fin de que también la vida de Jesús se manifieste en nuestro cuerpo» ( 2 Cor 4,10$)$. Pues sólo en la muerte fulgura la resurrección, sólo tras la personal experiencia del Viernes Santo se puede experimentar personalmente la Pascua, sólo en aceptadas situaciones de muerte e «invocando el nombre del Señor» es posible encontrar al Resucitado o experimentar su poder y señorío sobre toda realidad de muerte, pues «no quedará confundido quien en Él crea» y sí «experimentará la salvación el que invoque su nombre»: ¡El único «nombre dado [por Dios] a los hombres, para ser salvados»! ${ }^{258}$. Se comprende, pues, el anhelo de los verdaderos cristianos por configurarse del todo - incluso corporalmente - a la muerte de Jesús. Así lo deseó uno de los primeros mártires cristianos, considerándose «trigo de Dios que, por los dientes de las fieras, ha de ser molido para ser presentado como limpio pan de Cristo», y por ello rogó a los fieles romanos «no impedirle vivir» (sic!), obstaculizando de algún modo su martirio ${ }^{259}$. Análogo anhelo expresó también una enamorada del Crucificado y místicamente configurada con su muerte:

$$
\begin{aligned}
& \text { «Vivo sin vivir en mí, } \\
& \text { y tan alta vida espero, } \\
& \text { que muero porque no muero» }{ }^{260} \text {. }
\end{aligned}
$$

¡Es una muerte no asemejarse aún corporalmente a la muerte de Cristo y, con Él, participar de «tan alta vida»!. Así lo había expresado el más grande testigo antiguo de santidad cristiana, Pablo, anhelando «comunicar en los padecimientos». de Cristo «hasta asemejarse a Él en su muerte» y así experimentar ya «la resurrección de entre los muertos», pues «para mí la vida es Cristo y la muerte una ganancia», deseando por ello «partir y estar con Cristo»o «salir de este cuerpo, para vivir con el Señor» ${ }^{261}$. Y es que en la muerte corporal del cristiano alcanza su plenitud la bautismal y eucarística configuración a la «muerte» y «vida nueva» o resurrección con Cristo, por ser en realidad aquélla — como fue la de Jesús- un «pasar de este mundo al Padre» (Jn 13,1): ¡Una pascua!

b) La «muerte vital» del cristiano tiene a la vez la corredentora misión de vivificar a los muertos por el pecado: No sólo a quienes aún no han sido bautismalmente regenerados a la «vida nueva» $y$, por ello, participan aún de la

257. Jn 12,24-25; Mc 8,35par. 258. Rm 10,11-13; Act 2,21; 4,12. 259. San Ignacio A., Rom. IV 1; VI 2. 260. Sta. Teresa de Jesús, Obras completas, II 955-57. 261. Fil 3,10$11 ; 1,21.23 ; 2$ Cor 5,8 . 
«muerte» introducida «en el mundo por el pecado» de Adán, sino también a cuantos con sus pecados personales «llaman a la muerte» $\mathrm{y}$, alejados de «la casa» del Padre, «están muertos» ${ }^{262}$. Los discípulos de Jesús, en efecto, son llamados y enviados a «perder su vida por Él y por el Evangelio», pues en su necesaria condición de «siervos» tienen que «seguir las huellas» del Siervo de Dios y vivir «como» Él, que «vino... a dar su vida en rescate por todos» ${ }^{263}$. ¡Morir, para dar la vida al mundo!: Esta misión salvífica de Jesús prolongan en la tierra quienes Él «eligió y envió para dar fruto» duradero y por cierto «abundante, que glorifique al Padre», cuya fecundidad sin embargo - como la del «grano de trigo»- está condicionada por el dejarse «caer en la tierra»y «morir» $u$ «odiar la propia vida en este mundo» $y$ «perderla» — salud y tiempo, trabajo y dinero... - por las exigencias de la evangelización: i «Por Jesús y por el Evangelio»! ${ }^{264}$. Eso, exactamente, sugieren con claridad las tres metáforas, con que el Maestro ejemplificó a los discípulos su misión salvadora. «Vosotros sois la sal de la tierra» (Mt 5,13): como la sal sólo puede salar, si se diluye o desaparece - ¡muere! - entre los alimentos, también aquéllos «salan la tierra» o sazonan con el amor de Cristo a sus moradores, únicamente si se diluyen entre ellos o por ellos dan su vida. «Vosotros sois la luz del mundo» o la «antorcha» que con la «luz» de las «buenas obras» ilumina «a los hombres, para que glorifiquen al Padre celeste» (Mt 5,14-16): Como la antorcha o candela únicamente puede iluminar, si poco a poco se consume - ¡muere! - o se agota, también aquéllos sólo pueden «brillar como antorchas en el mundo»e iluminarlo con la «luz» de las «buenas obras» o práctica del Sermón de la Montaña así como de la evangelización ${ }^{265}$, si al precio de aquéllas y ésta se consumen o mueren. Los discípulos o comunidad mesiánica son también como «la levadura», que «fermenta toda la masa» humana (Mt 13,33par), debiendo por tanto - como aquélla - perderse entre ésta o morir, para poder fermentarla con el anuncio de la salvación y así convertirla en pan sabroso de Cristo, en alimento agradable a Dios.

Sal que se diluye, para salar la tierra; lámpara que se consume, para iluminar al mundo; levadura que desaparece, para fermentar la masa de los hombres: ¡Con su muerte vivifica la Iglesia al mundo! Así continúa ella la vivificante misión de Cristo, convencida de que «lo que el alma es en el cuerpo, eso son los cristianos en el mundo» ${ }^{266}$ : Mueren para vivificarlo, lo vivifican muriendo. Pues experimentan la debilidad o «llevan en vasos de barro el tesoro» de la evangelización, «para que la extraordinaria grandeza» del fruto conseguido por aquélla revele «el poder de Dios» sobre las tribulaciones y perple-

262. Rm 5,12; Sab 1,16; Lc 15,24.32. 263. Mc 8,3\$b; 1 Pe 2,21-24; Mt 20,26-28=Mc 10,43-45. 264. Jn 15,8.16; 12,24-25; Mc 8,35b. 265. Fil 2,15; Mt 5,16+Mc 4,21-22: La interpretación de «la lámpara» por Mt y Mc se complementa, pues si aquél la refiere a la praxis cristiana del Sermón de la Montaña (Mt 5,21ss) en este mundo, éste «la relaciona directamente con el evangelio» (J. Jeremias, Die Gleichnisse Jesu, Göttingen ${ }^{7} 1965, \cdot 120$ : trad. españ., 149). 266. Anónimo, Discurso a Diogneto, VI 1. 
jidades, las persecuciones y fracasos, sobre «la muerte por causa de Jesús», aceptada ésta en la convicción arraigada de que «LA MUERTE ACTÚA EN NOSOTROS, PERO CON ELLA OS DAMOS LA VIDA» (2Cor 4,7-12).

S. SABUGAL 